\title{
Article
}

\section{Osmotic and stimulant laxatives for the management of childhood constipation}

Gordon, Morris, Macdonald, John, Parker, Claire, Akobeng, Anthony and Thomas, Adrian

Available at http://clok.uclan.ac.uk/15372/

Gordon, Morris ORCID: 0000-0002-1216-5158, Macdonald, John, Parker, Claire, Akobeng, Anthony and Thomas, Adrian (2016) Osmotic and stimulant laxatives for the management of childhood constipation. cochrane library (8).

It is advisable to refer to the publisher's version if you intend to cite from the work. http://dx.doi.org/10.1002/14651858.CD009118.pub2

For more information about UCLan's research in this area go to

http://www.uclan.ac.uk/researchgroups/ and search for < name of research Group>.

For information about Research generally at UCLan please go to http://www.uclan.ac.uk/research/

All outputs in CLoK are protected by Intellectual Property Rights law, including Copyright law. Copyright, IPR and Moral Rights for the works on this site are retained by the individual authors and/or other copyright owners. Terms and conditions for use of this material are defined in the policies page. 


\section{(E) Cochrane Library}

Cochrane Database of Systematic Reviews

\section{Osmotic and stimulant laxatives for the management of childhood constipation (Review)}

Gordon M, MacDonald JK, Parker CE, Akobeng AK, Thomas AG

Gordon M, MacDonald JK, Parker CE, Akobeng AK, Thomas AG.

Osmotic and stimulant laxatives for the management of childhood constipation.

Cochrane Database of Systematic Reviews 2016, Issue 8. Art. No.: CD009118.

DOI: 10.1002/14651858.CD009118.pub3.

www.cochranelibrary.com 
TABLE OF CONTENTS

HEADER . . . . . . . . . . . . . . . . . . . . . . . . . . . . . . . . . . . . . . . . . . . . .

ABSTRACT . . . . . . . . . . . . . . . . . . . . . . . . . . . . . . . . . . . . . . . . . . . . . .

PLAIN LANGUAGE SUMMARY . . . . . . . . . . . . . . . . . . . . . . . . . . . . . . . . . . . . . . . . . . . . .

SUMMARY OF FINDINGS FOR THE MAIN COMPARISON . . . . . . . . . . . . . . . . . . . . . . . . . . . .

BACKGROUND . . . . . . . . . . . . . . . . . . . . . . . . . . . . . . . . . . . . . . . . . 6

OBJECTIVES . . . . . . . . . . . . . . . . . . . . . . . . . . . . . . . . . . . . . . . . . . . .

METHODS . . . . . . . . . . . . . . . . . . . . . . . . . . . . . . . . . . . . . . . .

RESULTS . . . . . . . . . . . . . . . . . . . . . . . . . . . . . . . . . . . . . . . . . . . .

Figure 1. . . . . . . . . . . . . . . . . . . . . . . . . . . . . . . . . . . . . . . . . . 9

Figure 2. . . . . . . . . . . . . . . . . . . . . . . . . . . . . . . . . . . . . . 10

Figure 3. . . . . . . . . . . . . . . . . . . . . . . . . . . . . . . . . . . . . . 11

Figure $4 . \quad$. . . . . . . . . . . . . . . . . . . . . . . . . . . . . . . . . . . . . . .

Figure 5. . . . . . . . . . . . . . . . . . . . . . . . . . . . . . . . . . . . . . 14

Figure 6. . . . . . . . . . . . . . . . . . . . . . . . . . . . . . . . . . . . . . . . 17

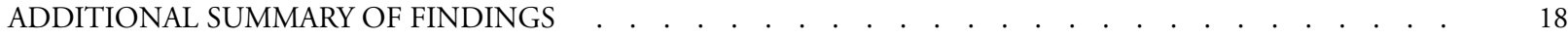

DISCUSSION . . . . . . . . . . . . . . . . . . . . . . . . . . . . . . . . . . . . . . . . . .

AUTHORS' CONCLUSIONS . . . . . . . . . . . . . . . . . . . . . . . . . . . . . . . . . . . . 37

ACKNOWLEDGEMENTS . . . . . . . . . . . . . . . . . . . . . . . . . . . . . . . . . . . . . . . .

REFERENCES . . . . . . . . . . . . . . . . . . . . . . . . . . . . . . . . . . . . . . . . 37

CHARACTERISTICS OF STUDIES . . . . . . . . . . . . . . . . . . . . . . . . . . . . . . . . . . . . . 41

DATA AND ANALYSES . . . . . . . . . . . . . . . . . . . . . . . . . . . . . . . . . . . . . . . . . . . . . . . 6

Analysis 1.1. Comparison 1 PEG versus placebo, Outcome 1 Frequency of defecation. . . . . . . . . . . . . . . 70

Analysis 1.2. Comparison 1 PEG versus placebo, Outcome 2 Serious adverse events. . . . . . . . . . . . . . . . 71

Analysis 2.1. Comparison 2 PEG versus Lactulose, Outcome 1 Frequency of defecation. . . . . . . . . . . . . . 72

Analysis 2.2. Comparison 2 PEG versus Lactulose, Outcome 2 Need for additional therapies. . . . . . . . . . . . 73

Analysis 2.3. Comparison 2 PEG versus Lactulose, Outcome 3 Need for additional therapies (sensitivity analysis). . 74

Analysis 2.4. Comparison 2 PEG versus Lactulose, Outcome 4 Successful disimpaction. . . . . . . . . . . . . . 74

Analysis 2.5. Comparison 2 PEG versus Lactulose, Outcome 5 Adverse events. . . . . . . . . . . . . . . . . . 75

Analysis 2.6. Comparison 2 PEG versus Lactulose, Outcome 6 Serious adverse events. . . . . . . . . . . . . . . . 76

Analysis 3.1. Comparison 3 PEG versus Milk of Magnesia, Outcome 1 Frequency of defecation. . . . . . . . . . 76

Analysis 3.2. Comparison 3 PEG versus Milk of Magnesia, Outcome 2 Frequency of defecation (sensitivity analysis excluding outlier). . . . . . . . . . . . . . . . . . . . . . . . . . . . . . . . . 77

Analysis 3.3. Comparison 3 PEG versus Milk of Magnesia, Outcome 3 Successful disimpaction. . . . . . . . . 78

Analysis 4.1. Comparison 4 PEG versus Enema, Outcome 1 Frequency of defecation. . . . . . . . . . . . . . . . . 78

Analysis 4.2. Comparison 4 PEG versus Enema, Outcome 2 Successful disimpaction. . . . . . . . . . . . . . . . 79

Analysis 5.1. Comparison 5 PEG versus Liquid Paraffin, Outcome 1 Frequency of defecation. . . . . . . . . . . 79

Analysis 6.1. Comparison 6 PEG versus Flixweed, Outcome 1 Frequency of defecation. . . . . . . . . . . . . . 80

Analysis 6.2. Comparison 6 PEG versus Flixweed, Outcome 2 Need for additional therapies. . . . . . . . . . . . . $\quad$. 80

Analysis 7.1. Comparison 7 PEG versus Dietary fibre mix, Outcome 1 Frequency of defecation. . . . . . . . . . . 81

Analysis 7.2. Comparison 7 PEG versus Dietary fibre mix, Outcome 2 Need for additional therapy. . . . . . . . . 81

Analysis 7.3. Comparison 7 PEG versus Dietary fibre mix, Outcome 3 Frequency of faecal incontinence. $\quad$. . . . . 82

Analysis 8.1. Comparison 8 High dose PEG versus low dose PEG, Outcome 1 Frequency of defecation. . . . . . . 82

Analysis 8.2. Comparison 8 High dose PEG versus low dose PEG, Outcome 2 Need for additional therapy. $\quad . \quad$. $\quad$. 83

Analysis 8.3. Comparison 8 High dose PEG versus low dose PEG, Outcome 3 Faecal incontinence. . . . . . . . 83

Analysis 8.4. Comparison 8 High dose PEG versus low dose PEG, Outcome 4 Adverse events. . . . . . . . . . . . . 84

Analysis 9.1. Comparison 9 Liquid Paraffin versus Lactulose, Outcome 1 Frequency of defecation. . . . . . . . . . . 84

Analysis 10.1. Comparison 10 Lactulose versus Lactitol, Outcome 1 Frequency of defecation. . . . . . . . . . . 85

Analysis 11.1. Comparison 11 Lactulose versus Milk of Magnesia, Outcome 1 Frequency of defecation. . . . . . . 85

Analysis 11.2. Comparison 11 Lactulose versus Milk of Magnesia, Outcome 2 Need for additional therapy. . . . . . 86

Analysis 11.3. Comparison 11 Lactulose versus Milk of Magnesia, Outcome 3 Successful disimpaction. . . . . $\quad$. $\quad 86$

Analysis 12.1. Comparison 12 Lactulose versus Partially Hydrolyzed Guar Gum, Outcome 1 Frequency of defecation. 87

Osmotic and stimulant laxatives for the management of childhood constipation (Review)

Copyright $\odot 2016$ The Cochrane Collaboration. Published by John Wiley \& Sons, Ltd. 
APPENDICES . . . . . . . . . . . . . . . . . . . . . . . . . . . . . . . . . . . . . . . . 8

WHAT'S NEW . . . . . . . . . . . . . . . . . . . . . . . . . . . . . . . . . . . . . . . . . . . . . $\quad . \quad 89$

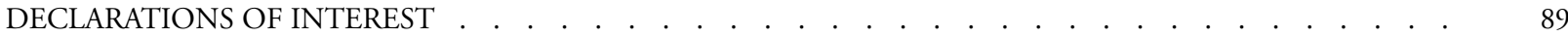

INDEX TERMS . . . . . . . . . . . . . . . . . . . . . . . . . . . . . . . . . . . . . . . . . . . . . . . 


\title{
[Intervention Review] \\ Osmotic and stimulant laxatives for the management of childhood constipation
}

\author{
Morris Gordon ${ }^{1,2}$, John K MacDonald ${ }^{3,4}$, Claire E Parker ${ }^{3}$, Anthony K Akobeng ${ }^{5}$, Adrian G Thomas ${ }^{6}$ \\ ${ }^{1}$ School of Medicine and Dentistry, University of Central Lancashire, Preston, UK. ${ }^{2}$ Families Division, Blackpool Victoria Hospital, \\ Blackpool, UK. ${ }^{3}$ Cochrane IBD Group, Robarts Clinical Trials, London, Canada. ${ }^{4}$ Department of Medicine, University of Western \\ Ontario, London, Canada. ${ }^{5}$ Sidra Medical \& Research Center, Doha, Qatar. ${ }^{6}$ Royal Manchester Children's Hospital, Manchester, UK \\ Contact address: Morris Gordon, School of Medicine and Dentistry, University of Central Lancashire, Preston, UK. \\ morris@betterprescribing.com.general@biyeeproperties.com.
}

Editorial group: Cochrane IBD Group.

Publication status and date: New search for studies and content updated (conclusions changed), published in Issue 8, 2016.

Review content assessed as up-to-date: 10 March 2016.

Citation: Gordon M, MacDonald JK, Parker CE, Akobeng AK, Thomas AG. Osmotic and stimulant laxatives for the management of childhood constipation. Cochrane Database of Systematic Reviews 2016, Issue 8. Art. No.: CD009118. DOI: 10.1002/14651858.CD009118.pub3.

Copyright (C) 2016 The Cochrane Collaboration. Published by John Wiley \& Sons, Ltd.

\begin{abstract}
A B S T R A C T
Background

Constipation within childhood is an extremely common problem. Despite the widespread use of osmotic and stimulant laxatives by health professionals to manage constipation in children, there has been a long standing paucity of high quality evidence to support this practice.
\end{abstract}

\section{Objectives}

We set out to evaluate the efficacy and safety of osmotic and stimulant laxatives used to treat functional childhood constipation.

\section{Search methods}

We searched MEDLINE, EMBASE, the Cochrane Central Register of Controlled Trials, and the Cochrane IBD Group Specialized Trials Register from inception to 10 March 2016. There were no language restrictions. We also searched the references of all included studies, personal contacts and drug companies to identify studies.

\section{Selection criteria}

Randomised controlled trials (RCTs) which compared osmotic or stimulant laxatives to placebo or another intervention, with participants aged 0 to 18 years old were considered for inclusion. The primary outcome was frequency of defecation. Secondary endpoints included faecal incontinence, disimpaction, need for additional therapies and adverse events.

\section{Data collection and analysis}

Relevant papers were identified and two authors independently assessed the eligibility of trials, extracted data and assessed methodological quality using the Cochrane risk of bias tool. The primary outcome was frequency of defecation. Secondary endpoints included faecal incontinence, disimpaction, need for additional therapies and adverse events. For continuous outcomes we calculated the mean difference (MD) and 95\% confidence interval (CI) using a fixed-effect model. For dichotomous outcomes we calculated the risk ratio (RR) and 95\% CI using a fixed-effect model. The $\mathrm{Chi}^{2}$ and $\mathrm{I}^{2}$ statistics were used to assess statistical heterogeneity. A random-effects model was used in situations of unexplained heterogeneity. We assessed the overall quality of the evidence supporting the primary and secondary outcomes using the GRADE criteria.

Osmotic and stimulant laxatives for the management of childhood constipation (Review)

Copyright $\odot 2016$ The Cochrane Collaboration. Published by John Wiley \& Sons, Ltd. 


\section{Main results}

Twenty-five RCTs (2310 participants) were included in the review. Fourteen studies were judged to be at high risk of bias due to lack of blinding, incomplete outcome data and selective reporting. Meta-analysis of two studies (101 patients) comparing polyethylene glycol (PEG) with placebo showed a significantly increased number of stools per week with PEG (MD 2.61 stools per week, $95 \%$ CI 1.15 to 4.08). Common adverse events in the placebo-controlled studies included flatulence, abdominal pain, nausea, diarrhoea and headache. Participants receiving high dose PEG $(0.7 \mathrm{~g} / \mathrm{kg})$ had significantly more stools per week than low dose PEG $(0.3 \mathrm{~g} / \mathrm{kg})$ participants $(1$ study, 90 participants, MD 1.30, 95\% 0.76 to 1.84). Meta-analysis of 6 studies with 465 participants comparing PEG with lactulose showed a significantly greater number of stools per week with PEG (MD 0.70 , 95\% CI 0.10 to 1.31), although follow-up was short. Patients who received PEG were significantly less likely to require additional laxative therapies. Eighteen per cent (27/154) of PEG patients required additional therapies compared to 31\% (47/150) of lactulose patients (RR 0.55, 95\% CI 0.36 to 0.83 ). No serious adverse events were reported with either agent. Common adverse events in these studies included diarrhoea, abdominal pain, nausea, vomiting and pruritis ani. Meta-analysis of 3 studies with 211 participants comparing PEG with milk of magnesia showed that the stools per week were significantly greater with PEG (MD 0.69, 95\% CI 0.48 to 0.89). However, the magnitude of this difference was quite small and may not be clinically significant. One child was noted to be allergic to PEG, but there were no other serious adverse events reported. One study found a significant difference in stools per week favouring milk of magnesia over lactulose (MD -1.51, 95\% CI -2.63 to - - 2.39, 50 patients), Meta-analysis of 2 studies with 287 patients comparing liquid paraffin (mineral oil) with lactulose revealed a relatively large statistically significant difference in the number of stools per week favouring liquid paraffin (MD 4.94, 95\% CI 4.28 to 5.61). No serious adverse events were reported. Adverse events included abdominal pain, distention and watery stools. No statistically significant differences in the number of stools per week were found between PEG and enemas (1 study, 90 patients, MD $1.00,95 \%$ CI -1.58 to 3.58), dietary fibre mix and lactulose ( 1 study, 125 patients, $P=0.481$ ), senna and lactulose ( 1 study, 21 patients, $\mathrm{P}>0.05$ ), lactitol and lactulose (1 study, 51 patients, MD -0.80, 95\% CI -2.63 to 1.03), hydrolyzed guar gum and lactulose (1 study, 61 patients, MD 1.00, 95\% CI -1.80 to 3.80), PEG and flixweed (1 study, 109 patients, MD 0.00, 95\% CI -0.33 to 0.33), PEG and dietary fibre (1 study, 83 patients, MD 0.20, 95\% CI -0.64 to 1.04), and PEG and liquid paraffin (2 studies, 261 patients, MD 0.35 , $95 \%$ CI -0.24 to 0.95$)$.

\section{Authors' conclusions}

The pooled analyses suggest that PEG preparations may be superior to placebo, lactulose and milk of magnesia for childhood constipation. GRADE analyses indicated that the overall quality of the evidence for the primary outcome (number of stools per week) was low or very low due to sparse data, inconsistency (heterogeneity), and high risk of bias in the studies in the pooled analyses. Thus, the results of the pooled analyses should be interpreted with caution because of quality and methodological concerns, as well as clinical heterogeneity, and short follow-up. There is also evidence suggesting the efficacy of liquid paraffin (mineral oil). There is no evidence to demonstrate the superiority of lactulose when compared to the other agents studied, although there is a lack of placebo controlled studies. Further research is needed to investigate the long term use of PEG for childhood constipation, as well as the role of liquid paraffin. The optimal dose of PEG also warrants further investigation.

\section{PLAIN LANGUAGESUMMARY}

\section{Laxatives for the management of childhood constipation}

\section{What is childhood constipation?}

Functional childhood constipation is a common problem. The term functional constipation is used when no underlying organic cause can be identified for the symptoms. Symptoms typically include decreased frequency of bowel movements, faecal incontinence and a change in consistency of stools. Despite the widespread use of laxatives by health professionals to manage constipation in children, there has been a long standing lack of evidence to support this practice.

\section{Review question}

The primary objective was to evaluate the effectiveness and side effects of osmotic and stimulant laxatives used for the treatment of functional childhood constipation.

\section{What are osmotic and stimulant laxatives?}

Osmotic laxatives are medications that draw water into the stool, resulting in softer stools and more frequent, easier to pass bowel movements. Some commonly used osmotic laxatives include polyethylene glycol (PEG), milk of magnesia, and lactulose. Stimulant 
laxatives induce bowel movements by increasing the contraction of muscles in the intestines. Examples of stimulant laxatives include aloe, cascara, senna compounds, bisacodyl, and castor oil.

\section{What did the researchers investigate?}

The researchers studied whether osmotic and stimulant laxatives are effective for the treatment of childhood constipation whether these medications cause any harms (side effects). The investigators searched the medical literature extensively up to 10 March June 2016.

\section{What did the researchers find?}

This review included 25 studies with a total of 2310 children that compared ten different agents to either placebo (inactive medications) or each other. Many of the studies were small in size and were judged to be of poor or unclear quality. The results of this review suggest that PEG preparations may increase the frequency of bowel movements in constipated children. There is evidence from one study that suggests that high dose PEG $(0.7 \mathrm{~g} / \mathrm{kg})$ may be superior to low dose PEG $(0.3 \mathrm{~g} / \mathrm{kg})$ for increasing the frequency of bowel movements in constipated children. The rates of minor side effects were generally lower compared to other agents. Common side effects included flatulence, abdominal pain, nausea, diarrhoea and headache. There was also some evidence that liquid paraffin (mineral oil) increased the frequency of bowel movements in constipated children. Common side effects with liquid paraffin included abdominal pain, distention and watery stools. There was no evidence to suggest that lactulose is superior to the other agents studied, although there were no trials comparing it to placebo (a fake medicine such as a sugar pill). These studies were relatively short in duration and so it is difficult to assess the long term effectiveness of these agents for the treatment of childhood constipation. Long term effectiveness is important, given the often chronic nature of this problem in children.

The results of the review should be interpreted with caution due to quality issues in the included studies. As such, the strength of our conclusions is extremely limited and more research is needed. Key questions that need addressing include the safety of liquid paraffin, given its apparent effectiveness, but limited investigation. In particular, future research should compare liquid paraffin to PEG. The optimal dose of PEG warrants further investigation. The role of PEG for the long term management of chronic constipation also needs further investigation to allow research to better inform actual clinical practice. There is a lack of studies comparing lactulose with placebo.

Osmotic and stimulant laxatives for the management of childhood constipation (Review) 


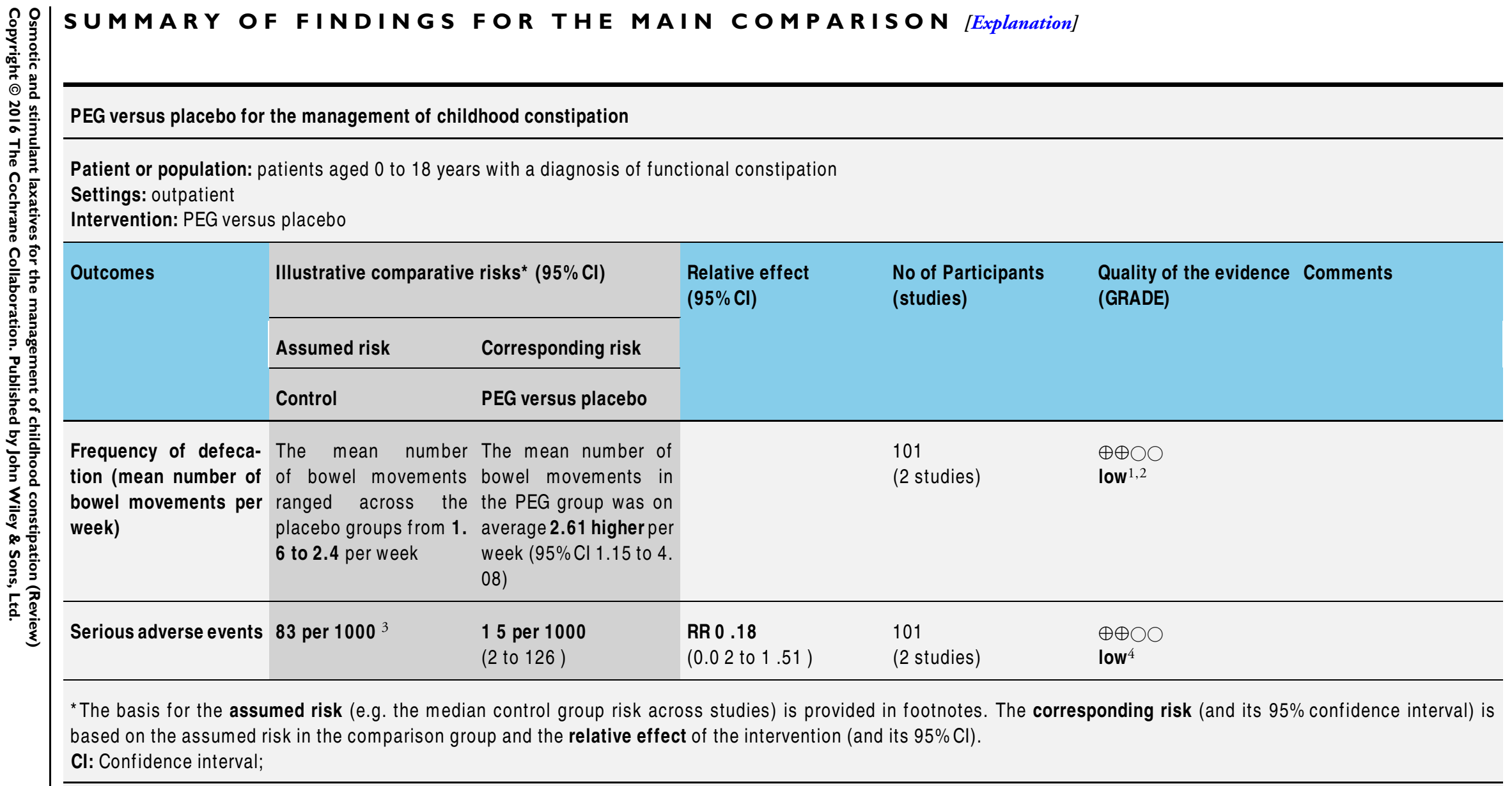

GRADE Working Group grades of evidence

High quality: Further research is very unlikely to change our confidence in the estimate of effect.

Moderate quality: Further research is likely to have an important impact on our confidence in the estimate of effect and may change the estimate.

Low quality: Further research is very likely to have an important impact on our confidence in the estimate of effect and is likely to change the estimate.

Very low quality: We are very uncertain about the estimate.

${ }^{1}$ Downgraded one level due to sparse data (101 patients).

${ }^{2}$ Downgraded one level due to inconsistency (moderate statistical heterogeneity $\mathrm{I}^{2}=58 \%$ ).

- ${ }^{3}$ Control group risk comes from control arm of meta-analysis, based on included trials. 


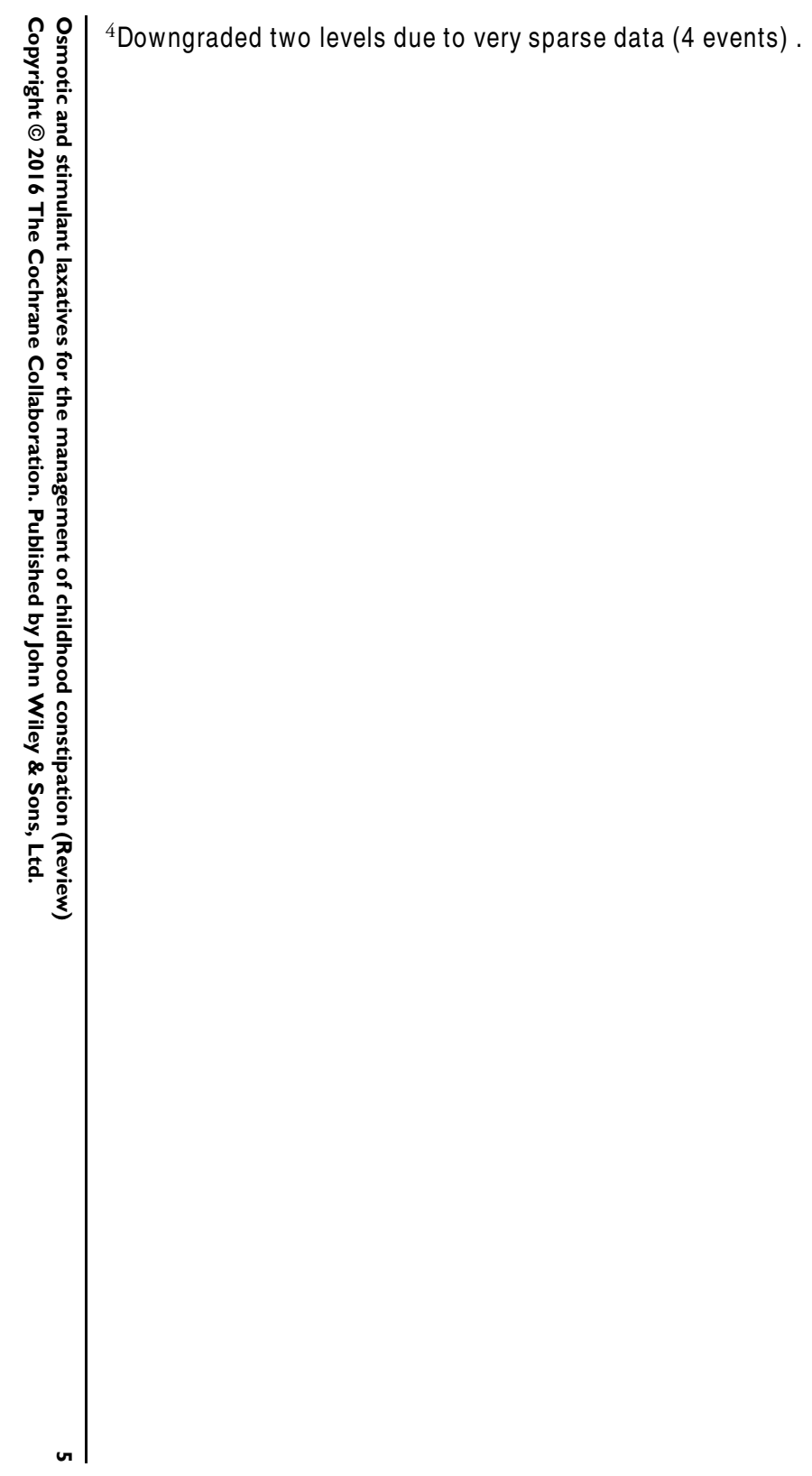




\section{B A C K G R O U N D}

\section{Description of the condition}

Constipation within childhood is an extremely common problem (Van den Berg 2006), representing the chief complaint in 3\% of visits to general paediatric clinics and as many as $30 \%$ of visits to paediatric gastroenterologists (Partin 1992). The term functional constipation is used when no underlying organic cause can be identified for the symptoms. Creating a workable diagnostic classification for functional constipation has proven difficult. Criteria vary, but are mostly based on a variety of symptoms, including decreased frequency of bowel movements, faecal incontinence and a change in consistency of stools (Pijpers 2008).

A team of paediatricians met in 1997 in Rome to standardize the diagnostic criteria for various functional gastroenterological disorders in children. The first paediatric Rome II criteria were published in 1999 (Rasquin-Weber 1999) and were updated during the Rome III process in 2006, producing guidance for functional constipation for neonates, toddlers and children (Hyman 2006; Rasquin 2006).

To diagnose constipation using the Rome III criteria, at least two of the symptoms below must be present for at least one month in infants and children up to age four and at least two months in children over four, with insufficient criteria for the diagnosis of irritable bowel syndrome:

- Two or fewer defecations per week;

- At least one episode per week of incontinence after the acquisition of toileting skills;

- History of retentive posturing or excessive voluntary stool retention (over 4 years) or excessive stool retention (under 4 years);

- History of painful or hard bowel movements;

- Presence of a large faecal mass in the rectum; and

- History of large diameter stools which may obstruct the toilet.

Effective management of childhood functional constipation depends on securing a therapeutic alliance with the parents, particularly through the first years when children cannot accurately report symptoms. Clinicians depend on the reports and interpretations of the parents, who know their child best, and their own training and experience to differentiate between health and illness (Hyman 2006).

\section{Description of the intervention}

Laxative therapies are often the mainstay of medical therapy used in children suffering with functional constipation, alongside adjuvant therapies such as dietary and behavioural modification. Osmotic laxatives, such as lactulose, milk of magnesia and polyethylene glycol (PEG), are usually supplied as solutions or powders to be dissolved in water and are therefore relatively easy to administer to young children. Stimulant laxatives, such as Senna and Bisacodyl, come in a variety of forms, including tablets, liquids, and suppositories.

\section{How the intervention might work}

Osmotic laxatives are poorly absorbed in the gut. They act as hyperosmolar agents, increasing water content of stool and therefore making stool softer and easier to pass, as well as increasing colonic peristalsis. Stimulant laxatives act on the intestinal mucosa, increasing water and electrolyte secretion. They also stimulate peristaltic action.

\section{Why it is important to do this review}

Despite the widespread use of these medications by health professionals to manage constipation in children, there has been a long standing paucity of high quality evidence to support this practice. Previous efforts have been made to produce guidance on this topic (Baker 1999; Anonymous 2006), most recently by the National Institute for Health and Clinical Excellence in the UK (Anonymous 2010).

In recent years, the widespread introduction of PEG to paediatric practice has led to a resurgence in research on paediatric constipation. Some studies have suggested that PEG has greater efficacy when compared with placebo (Thomson 2007), as well as when compared to lactulose (Voskujl 2004; Candy 2006).

A recently published Cochrane review investigated the specific comparison of PEG versus lactulose in children and adults (Lee-Robichaud 2010). There currently exists no other systematic review using the Cochrane collaboration format for the use of osmotic laxatives in children. A previous Cochrane review evaluating the effect of stimulant laxatives on constipation in children found no studies of sufficient quality to allow evaluation (Price 2001). An up to date systematic review using the Cochrane Collaboration format is indicated to summarise the current evidence on the use of osmotic and stimulant laxatives for the management of constipation in children. This systematic review is an update of a previously published Cochrane review (Gordon 2012; Gordon 2013).

\section{O B J E C T I VES}

The primary objectives are to evaluate the efficacy and safety of osmotic and stimulant laxatives used to treat functional childhood constipation. 


\section{METHODS}

\section{Criteria for considering studies for this review}

\section{Types of studies}

Randomised controlled trials were considered for inclusion.

\section{Types of participants}

Patients aged 0 to 18 years with a diagnosis of functional constipation, with or without incontinence were considered for inclusion. The diagnosis of constipation was patient self-reported, physician diagnosed, or by consensus criteria (e.g. Rome III). Studies with patients suffering from any underlying pathology, such as thyroid abnormalities, Hirschsprung's disease or having undergone previous bowel surgery at study entry, were excluded.

\section{Types of interventions}

Studies comparing osmotic or stimulant laxatives with another intervention or placebo were considered for inclusion. All preparations and dosing regimes were considered. Studies using multiple osmotic or stimulant laxative combinations or combinations of both as their intervention were also considered for inclusion.

\section{Types of outcome measures}

\section{Primary outcomes}

The primary outcome measure was the frequency of defecation (number of stools per week).

\section{Secondary outcomes}

Secondary outcomes included:

1) Faecal incontinence;

2) Disimpaction;

4) Need for additional therapies; and

5) Adverse events.

\section{Search methods for identification of studies}

\section{Electronic searches}

A computer-assisted search for relevant studies (from database inception to 10 March 2016) was performed using MEDLINE, EMBASE and the Cochrane Central Register of Controlled Trials and the Cochrane IBD Group Specialized Register (Appendix 1). References from published articles and conference proceedings were searched to identify additional citations.
There is some evidence that data from abstracts can be inconsistent with data in published articles (Pitkin 1999), therefore abstract publications were not included in this review.

\section{Searching other resources}

B. Reference searching

The references of all identified studies were inspected for more trials.

C. Personal contacts

Leaders in the field were contacted to try to identify other studies. D. Drug companies

The manufacturers of osmotic and stimulant laxative agents were contacted for additional data.

\section{Data collection and analysis}

All identified abstracts and results from searches were reviewed by two authors (MG and $\mathrm{KN}$ ). If the reference appeared relevant, a full copy of the study was obtained.

\section{Selection of studies}

Two authors (MG and KN), after reading the full texts, independently assessed the eligibility of all trials identified based on the inclusion criteria above. Disagreement among authors was discussed and agreement reached by consensus.

\section{Data extraction and management}

A data extraction form was developed and piloted to extract information on relevant features and results of included studies. The two reviewers separately extracted and recorded data on the predefined checklist.

Extracted data included the following items:

a. characteristics of patients: age, sex, duration of symptoms;

b. study methods, total number of patients originally assigned to each treatment group;

c. intervention: preparations, dose, administration regime;

d. control: placebo, other drugs;

e. concurrent medications;

f. outcomes (time of assessment, length of follow-up, frequency of defecation, pain on defecation and/or straining, faecal incontinence, stool consistency, need for additional therapies, number and type of adverse events associated with treatment, adverse events); and g. withdrawals and reasons for withdrawals.

\section{Assessment of risk of bias in included studies}

The methodological quality of selected trials was assessed independently by two authors using the Cochrane risk of bias tool (Higgins 2011a). Factors assessed included: 
1. sequence generation (i.e. was the allocation sequence adequately generated?);

2. allocation sequence concealment (i.e. was allocation adequately concealed?);

3. blinding (i.e. was knowledge of the allocated intervention adequately prevented during the study?);

4. incomplete outcome data (i.e. were incomplete outcome data adequately addressed?);

5. selective outcome reporting (i.e. are reports of the study free of suggestion of selective outcome reporting?); and

6. other potential sources of bias (i.e. was the study apparently free of other problems that could put it at a high risk of bias?).

A judgement of 'Yes' indicates low risk of bias, 'No' indicates high risk of bias, and 'Unclear' indicates unclear or unknown risk of bias. Disagreements was resolved by consensus. Study authors were contacted for further information when insufficient information was provided to determine the risk of bias.

We used the GRADE approach for rating the overall quality of evidence for the primary outcome. Randomised trials start as high quality evidence, but may be downgraded due to: (1) risk of bias, (2) indirectness of evidence, (3) inconsistency (unexplained heterogeneity), (4) imprecision (sparse data), and (5) reporting bias (publication bias). The overall quality of evidence for each outcome was determined after considering each of these elements, and categorized as high quality (i.e. further research is very unlikely to change our confidence in the estimate of effect); moderate quality (i.e. further research is likely to have an important impact on our confidence in the estimate of effect and may change the estimate); low quality (i.e. further research is very likely to have an important impact on our confidence in the estimate of effect and is likely to change the estimate); or very low quality (i.e. we are very uncertain about the estimate) (Guyatt 2008; Schünemann 2011).

\section{Measures of treatment effect}

For the primary outcome, frequency of defecation, we calculated the mean difference (MD) and corresponding 95\% confidence interval (CI). For the secondary dichotomous outcomes we calculated the risk ratio (RR) and corresponding 95\% CI.

\section{Dealing with missing data}

The authors of included studies were contacted to supply any missing data.

\section{Assessment of heterogeneity}

Heterogeneity among trial results was assessed by visual inspection of forest plots and by calculating the $\mathrm{Chi}^{2}$ square test for heterogeneity (a P value of 0.10 was regarded as statistically significant). We also used the $\mathrm{I}^{2}$ statistic to quantity the effect of heterogeneity (Higgins 2003). A random-effects model was used in situations of unexplained heterogeneity. We aimed to further investigate potential sources of heterogeneity.

\section{Assessment of reporting biases}

If an appropriate number of studies was found, we aimed to investigate the possibility of a publication bias through the construction of funnel plots (trial effects versus trial size).

\section{Data synthesis}

For outcomes that were sufficiently homogenous, meta-analysis was carried out using a fixed-effect model. A random-effects model was used in situations of unexplained heterogeneity.

\section{Subgroup analysis and investigation of heterogeneity}

Subgroup analyses were to be carried out to further study the effects of a number of variables on the outcomes including: a. whether patients were being inducted in to 'remission' from constipation or whether this was a study of 'maintenance' therapy; b. the effect of length of therapy / follow-up; and c. specifically what, if any agents, were initially allowed in the protocol to clear any impaction (such as enemas).

\section{Sensitivity analysis}

Sensitivity analyses was conducted based on the following: a. only including patients' whose outcome is known i.e. number of patients who completed the study used as denominator; and b. random-effects versus fixed-effect models.

We also planned to consider the effect of:

c. allocation concealment;

d. type of agent;

e. dose of agent; and

f. concurrent medications.

\section{RE S U L T S}

\section{Description of studies}

A literature search conducted on 10 March 2016 identified 763 studies. Four additional studies were identified through searching of references. After duplicates were removed a total of 668 reports remained for review of titles and abstracts. Two authors independently reviewed the titles and abstracts of these studies 49 studies were selected for full text review (See Figure 1). Nineteen reports of 18 studies were excluded (See Characteristics of excluded studies). Thirty reports of 25 studies involving a total of 2310 patients were selected for inclusion (Bekkali 2009; Candy 2006; Dupont 2005; Dziechciarz 2015; Farahmand 2007; Gomes 2011; Gremse 2002; Karami 2009; Kokke 2008; LoeningBaucke 2006; Nimrouzi 2015; Nurko 2008; Perkin 1977; Pitzalis 1995; Quitadamo 2012; Rafati 2011; Ratanamongkol 2009; 
Saneian 2012; Thomson 2007; Tolia 1993; Treepongkaruna 2014;

Urganci 2005; Ustundag 2010; Voskujl 2004; Wang 2007) (See

Characteristics of included studies).

Figure I. Study flow diagram.

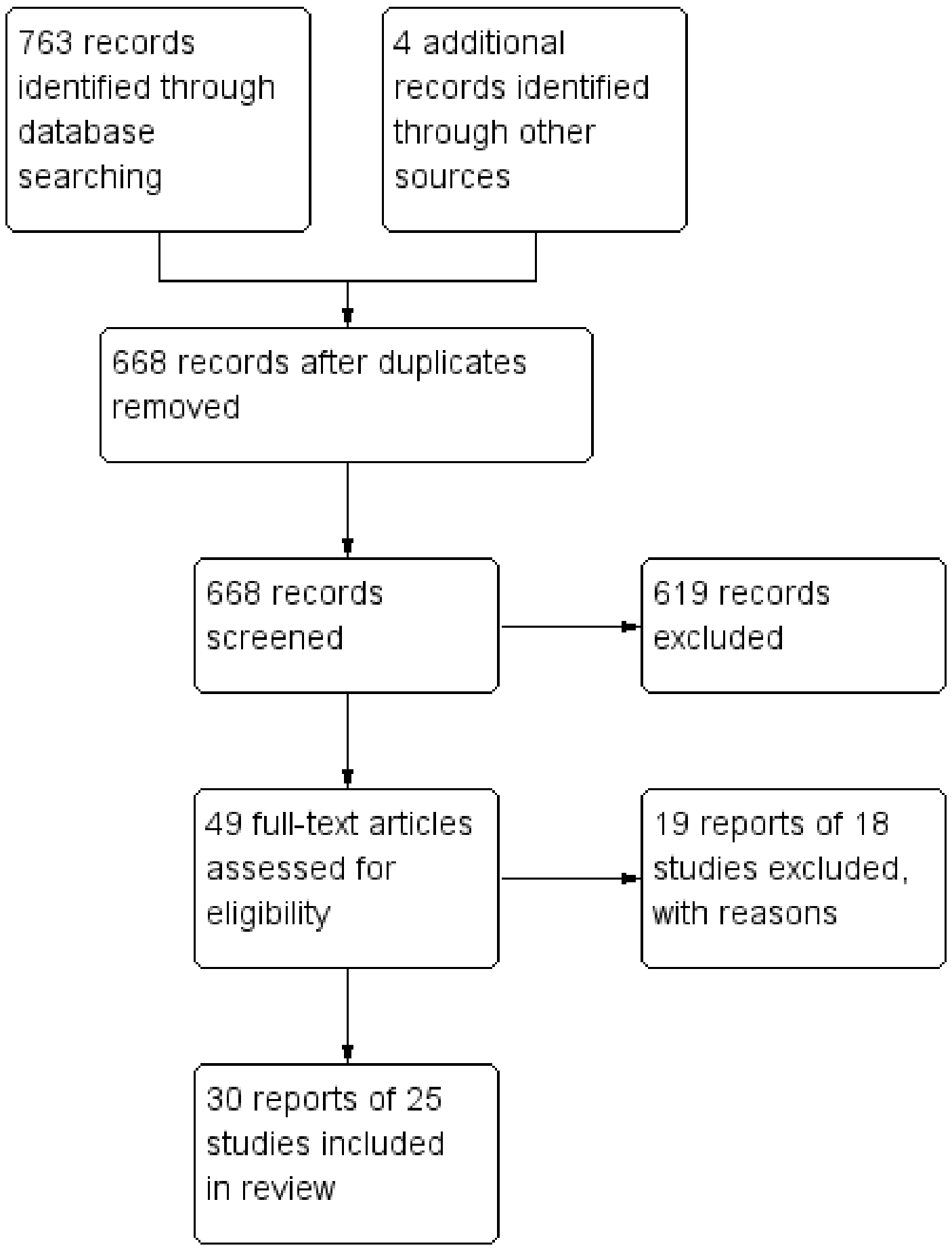


Eighteen studies were excluded for various reasons. Five studies were not randomised controlled trials (Dupont 2005; Hardikar 2007; Hejl 1990; Shevtsov 2005; Sonheimer 1982), two studies included adult patients (Corazziari 1996; Ferguson 1999), one study included adult and paediatric participants without reporting separate results for children (Connolly 1974), one study was of children with soiling (Berg 1983), two studies focused on the treatment of children with faecal impaction rather than functional constipation (Miller 2012; Youssef 2002); one study was of children with underlying bowel pathology (Kazak 1999); three studies looked at combination therapy with PEG compared to PEG by itself ( Bongers 2009; Dehghani 2014; Khoshoo 2006); one study compared one formulation of PEG to another (Savino 2012), and two studies were abstract publications (Bekkali 2009; Ormarsson 2013).

Two studies compared PEG to placebo (Thomson 2007; Nurko 2008), five compared PEG with lactulose (Gremse 2002; Voskujl 2004; Dupont 2005; Candy 2006; Wang 2007), three compared
PEG with milk of magnesia (magnesium oxide) (Loening-Baucke 2006, Gomes 2011, Ratanamongkol 2009), two compared liquid paraffin with lactulose (Urganci 2005; Farahmand 2007) two compared liquid paraffin with PEG (Tolia 1993; Rafati 2011), one compared PEG with enemas (Bekkali 2009), one compared a dietary fibre mix with lactulose (Kokke 2008), one lactulose with senna (Perkin 1977) and one lactitol with lactulose (Pitzalis 1995). The age of participants ranged from 6 months up to 16 years. The duration of the studies varied from 2 weeks to 12 months. The specific criteria for a diagnosis of constipation also varied between studies, as did the minimum length of symptoms. All studies excluded children with organic causes for their pathology (see characteristics of included studies).

\section{Risk of bias in included studies}

The risk of bias analysis for the included studies is summarised in Figure 2 and Figure 3.

Figure 2. Methodological quality graph: review authors' judgements about each methodological quality item presented as percentages across all included studies.

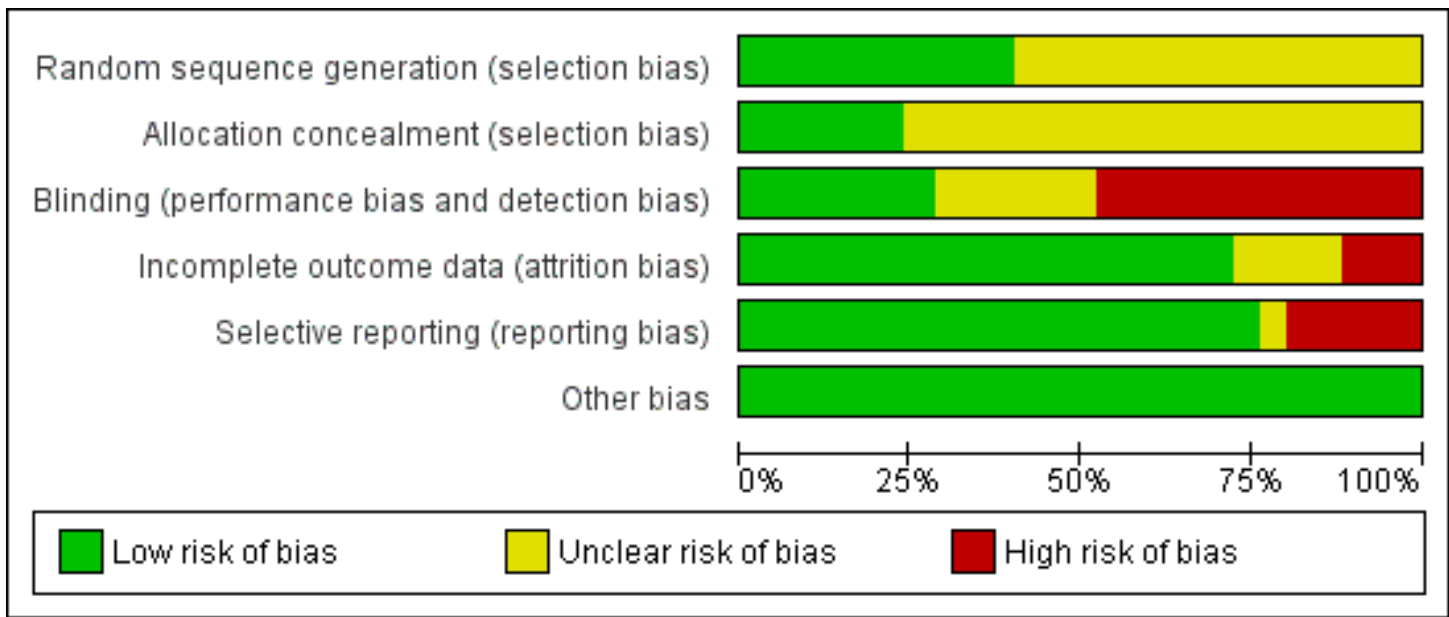

Osmotic and stimulant laxatives for the management of childhood constipation (Review) 
Figure 3. Methodological quality summary: review authors' judgements about each methodological quality item for each included study.

\begin{tabular}{|c|c|c|c|c|c|c|}
\hline & 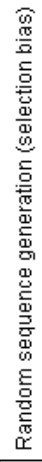 & 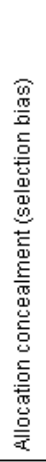 & 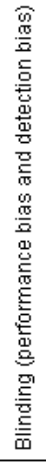 & 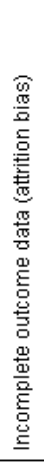 & 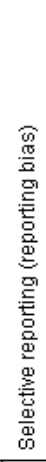 & 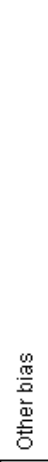 \\
\hline Bekkali 2009 & $?$ & $?$ & $\odot$ & + & & + \\
\hline Candy 2006 & + & $?$ & + & + & + & + \\
\hline Dupont 2005 & $?$ & $?$ & + & + & + & + \\
\hline Dziechciarz 2015 & + & + & $\odot$ & + & + & + \\
\hline Farahmand 2007 & $?$ & $?$ & $\odot$ & 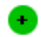 & $\odot$ & + \\
\hline Gomes 2011 & $?$ & ? & - & - & & + \\
\hline Gremse 2002 & $?$ & $?$ & - & + & & + \\
\hline Karami 2009 & $?$ & $?$ & $\odot$ & C & + & + \\
\hline Kokke 2008 & + & + & + & 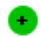 & 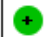 & + \\
\hline Loening-Baucke 2006 & + & + & $\odot$ & + & + & + \\
\hline Nimrouzi 2015 & $?$ & ? & - & $?$ & + & + \\
\hline Nurko 2008 & $?$ & $?$ & + & + & + & + \\
\hline Perkin 1977 & $?$ & + & $?$ & + & + & + \\
\hline Pitzalis 1995 & $?$ & $?$ & $?$ & + & - & + \\
\hline Quitadamo 2012 & $?$ & $?$ & - & $?$ & + & + \\
\hline Rafati 2011 & $?$ & $?$ & $?$ & 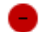 & - & + \\
\hline Ratanamongkol 2009 & + & + & $?$ & + & + & + \\
\hline Saneian 2012 & + & $?$ & $\odot$ & $?$ & + & + \\
\hline Thomson 2007 & + & + & 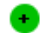 & + & + & + \\
\hline Tolia 1993 & + & $?$ & - & + & + & + \\
\hline Treepongkaruna 2014 & + & ? & + & + & + & + \\
\hline Urganci 2005 & $?$ & ? & - & + & + & + \\
\hline Ustundag 2010 & $?$ & $?$ & $?$ & + & ? & + \\
\hline Voskujl 2004 & $?$ & $?$ & + & + & + & + \\
\hline Wang 2007 & + & $?$ & $?$ & $?$ & + & + \\
\hline
\end{tabular}




\section{Allocation}

In nine of the included studies, the method of random allocation of participants to intervention groups was described and was judged to be adequate (Tolia 1993; Loening-Baucke 2006; Thomson 2007; Wang 2007; Kokke 2008; Ratanamongkol 2009; Saneian 2012; Treepongkaruna 2014; Dziechciarz 2015). These studies were rated as low risk of bias for sequence generation. For one study (Candy 2006), the sponsor responded to a request for more details and confirmed adequate sequence generation. This study was rated as low risk of bias for sequence generation. Allocation was described as random in the 15 remaining studies, although the method of randomisation was not described. These studies were rated as unclear risk of bias for sequence generation. Allocation concealment was rated as low risk of bias in six studies (Perkin 1977; Loening-Baucke 2006; Thomson 2007; Kokke 2008; Ratanamongkol 2009; Dziechciarz 2015), and as unclear risk of bias for the other studies.

\section{Blinding}

Methods for blinding were described and judged to be adequate in seven studies. These studies were rated as low risk of bias for blinding (Voskujl 2004; Dupont 2005; Candy 2006; Thomson 2007; Kokke 2008; Nurko 2008; Treepongkaruna 2014). In six studies, the use of blinding was reported but not described clearly. These studies were rated as unclear risk of bias for blinding (Perkin 1977; Pitzalis 1995; Wang 2007; Ratanamongkol 2009; Ustundag 2010; Rafati 2011). Saneian 2012 did not describe the use of blinding but clearly reported that no patients received placebo. This study was rated as high risk of bias for blinding. The remaining 11 studies were described as open label or single-blind and were rated as high risk of bias for blinding (Tolia 1993; Gremse 2002; Urganci 2005; Loening-Baucke 2006; Farahmand 2007; Bekkali 2009; Karami 2009; Gomes 2011; Quitadamo 2012; Dziechciarz 2015; Nimrouzi 2015).

\section{Incomplete outcome data}

Three studies were judged to be at high risk of bias for incomplete outcome data (Karami 2009; Gomes 2011, Rafati 2011). Four studies were rated as unclear risk of bias because drop outs were no adequately described (Wang 2007; Quitadamo 2012; Saneian 2012; Nimrouzi 2015). The remaining studies were judged to be at low risk of bias because drop outs were balanced across treatment groups with similar reasons for withdrawal or there were few drop outs.

\section{Selective reporting}

In five studies, the authors did not report on adverse event outcomes and therefore these studies were judged to be at risk of bias for selective reporting (Pitzalis 1995; Gremse 2002; Bekkali 2009; Gomes 2011; Rafati 2011). One study was judged to be at unclear risk of bias because adverse events were not adequately reported. The remaining studies were judged to be at low risk of bias for selective reporting.

\section{Other potential sources of bias}

None of the studies appeared to have any other potential sources of bias other than industry funding. All of the studies were rated as low risk of bias for other potential sources of bias. One study stated that they were supported by a pharmaceutical company, but details of the extent of involvement were unclear (Candy 2006). Two studies were sponsored by pharmaceutical companies, but confirmation was received that industry had no involvement in the conduct of the studies or the writing up of the results (Thomson 2007; Nurko 2008).

\section{Effects of interventions}

See: Summary of findings for the main comparison PEG versus placebo for the management of childhood constipation; Summary of findings 2 PEG versus lactulose for the management of childhood constipation; Summary of findings 3 PEG versus milk of magnesia (MOM) for the management of childhood constipation; Summary of findings 4 PEG versus enema for the management of childhood constipation; Summary of findings 5 PEG versus paraffin for the management of childhood constipation; Summary of findings 6 PEG versus flixweed for the management of childhood constipation; Summary of findings 7 PEG versus dietary fibre for the management of childhood constipation; Summary of findings 8 High dose PEG versus low dose PEG for the management of childhood constipation; Summary of findings 9 Liquid paraffin (mineral oil) versus lactulose for the management of childhood constipation; Summary of findings $\mathbf{1 0}$ Lactulose versus lactitol for the management of childhood constipation; Summary of findings 11 Lactulose versus milk of magnesia (MOM) for the management of childhood constipation; Summary of findings 12 Lactulose versus partially hydrolyzed guar gum (PHGG) for the management of childhood constipation

For the analyses, we used the total number of patients randomised as the denominator. In all analyses, the frequency of defecation was measured as stools per week. 
The published results for the two studies concerning 101 patients were inadequate to allow pooling for meta-analysis. The authors were contacted and directed us to the study sponsors who supplied unpublished data to allow analysis for outcomes at two weeks. One of the studies used multiple dosing regimens, but data were obtained for the dose of $0.8 \mathrm{~g} / \mathrm{kg}$ (Nurko 2008).

\section{Efficacy}

Frequency of defecation
Heterogeneity was noted to be moderate $\left(\mathrm{P}=0.12, \mathrm{I}^{2}=58 \%\right)$ and using a random-effects model, the MD was 2.61 stools per week (95\% CI 1.15 to 4.08), favouring PEG over placebo, see Analysis 1.1 and Figure 4. The GRADE analysis indicated that the overall quality of the evidence for the primary outcome (frequency of defecation) was low due to sparse data (101 patients) and inconsistency (statistical heterogeneity $\mathrm{I}^{2}=58 \%$ ) in the pooled analysis (See Summary of findings for the main comparison).

Figure 4. Forest plot of comparison: I PEG versus Placebo, outcome: I.I Frequency of defecation.

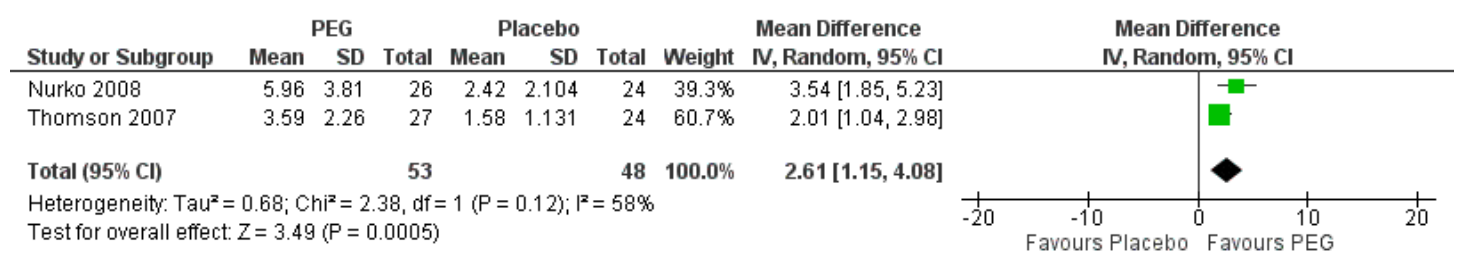

Episodes of faecal incontinence

At two weeks, both studies reported higher rates of faecal incontinence in the PEG group. As there was some discrepancy in baseline data between groups in one study (Nurko 2008), and the difference before and after treatment was not reported, meta-analysis for this outcome was not completed.

\section{Safety}

Serious adverse events were not reported in the PEG groups in either study, but were seen in the placebo groups ( $8 \%$ of placebo patients experienced a serious adverse event). However, there was no statistically significant difference in the incidence of serious adverse events using a fixed-effect model (RR $0.18,95 \%$ CI 0.02 to 1.51). A sensitivity analysis using a random-effects model did not have any impact on the results (RR 0.19, 95\% 0.02 to 1.63). Minor adverse events were common and included flatulence, abdominal pain, nausea, diarrhoea and headache. However, data were not reported to allow meta-analysis. The studies both stated that no difference in the incidence of adverse events appeared to exist between the groups.

\section{PEG versus Lactulose}

One of the seven studies did not report data that could be used for meta-analysis (Wang 2007). The authors were contacted, but no response was received and so the remaining 6 studies including 465 patients were analysed. One study reported separate results for babies and toddlers (Dupont 2005). Using the method described in the Cochrane handbook (Higgins 2011b), the mean and standard deviation for the entire sample were estimated.

\section{Efficacy}

Frequency of defecation

Heterogeneity was noted to be high $\left(\mathrm{P}=0.007, \mathrm{I}^{2}=69 \%\right)$ and using a random-effects model a statistically significant difference in favour of PEG over lactulose was seen, with a MD of 0.70 stools per week (95\% CI 0.10 to 1.31), see Analysis 2.1 and Figure 5. The GRADE analysis indicated that the overall quality of the evidence for the primary outcome (frequency of defecation) was very low due to inconsistency (statistical heterogeneity $\mathrm{I}^{2}=69 \%$ ), and a high risk of bias (i.e. lack of blinding and selective reporting) in two studies in the pooled analysis (See Summary of findings 2).

Osmotic and stimulant laxatives for the management of childhood constipation (Review) 
Figure 5. Forest plot of comparison: 2 PEG versus Lactulose, outcome: 2.I Frequency of defecation.

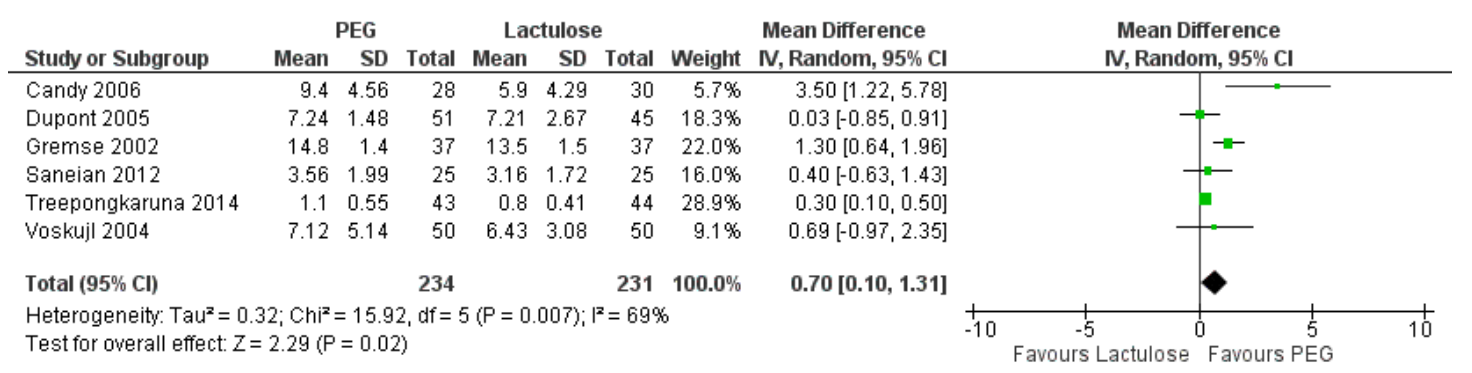

Need for additional therapies

Using a fixed-effect model, there was a statistically significant result favouring PEG over lactulose. For the 4 studies (304 patients) that reported this outcome (Voskujl 2004; Dupont 2005; Candy 2006; Saneian 2012), 18\% (27/154) of PEG patients required additional therapy compared to $31 \%(47 / 150)$ of lactulose patients, (RR $0.55,95 \%$ CI 0.36 to 0.83 ), see Analysis 2.2. The GRADE analysis indicated that the overall quality of the evidence supporting this outcome was low due high risk of bias (i.e. lack of blinding) and sparse data (74 events; See Summary of findings 2). When a sensitivity analysis using a random-effects model was calculated the results were no longer statistically significant (RR 0.59, 95\% CI 0.33 to 1.04 ), see Analysis 2.3.

Successful disimpaction

For the one study that reported this outcome (Saneian 2012), $100 \%$ of PEG participants were successfully disimpacted compared to $80 \%$ of lactulose patients (RR $1.24,95 \%$ CI 1.01 to 1.53; $\mathrm{P}=0.04)$. The GRADE analysis indicated that the overall quality of the evidence supporting this outcome was low due to high risk of bias (i.e. lack of blinding) and sparse data (45 events; See Summary of findings 2).

Safety

Minor adverse events were seen in most studies, but were not reported in one study (Gremse 2002). Common adverse events included diarrhoea ( Saneian 2012; Wang 2007) , abdominal pain (Saneian 2012; Wang 2007), bloating (Saneian 2012), nausea, vomiting (Treepongkaruna 2014), impacted faeces (Treepongkaruna 2014), and pruritis ani (Treepongkaruna 2014). For the 3 studies (242 patients) that reported data allowing meta-analysis (Dupont 2005; Candy 2006; Treepongkaruna 2014), there was no statistically significant difference in the proportion of patients who experienced at least one adverse event. Thirty-seven per cent (46/123) of PEG patients experienced at least one adverse event compared to $45 \%$ (54/119) of lactulose patients (RR 0.87, 95\% CI 0.68 to 1.11 ), see Analysis 2.5. The GRADE analysis indicated that the overall quality of the evidence supporting this outcome was moderate due to sparse data (100 events; See Summary of findings 2).

Serious adverse events were reported in two studies (Candy 2006;
Treepongkaruna 2014). Candy 2006 reported a chest infection in a patient in the PEG group, thought to be unrelated to therapy. Serious adverse events reported in the Treepongkaruna 2014 study include pneumonia and a traffic accident in the PEG 4000 group and a varicella infection in the lactulose group. None of these events were considered to be related to the study drug. There was no statistically significant difference in the proportion of patients who experienced a serious adverse event. Four per cent (3/71) of PEG participants had a serious adverse event compared to $1 \%$ (1/ 74) of lactulose participants (RR 2.43, 95\% CI 0.37 to 15.96 ). The GRADE analysis indicated that the overall quality of the evidence supporting this outcome was low due to very sparse data (4 events; See Summary of findings 2).

\section{PEG versus Milk of Magnesia}

Four studies (261 participants) compared PEG to milk of magnesia (Loening-Baucke 2006; Ratanamongkol 2009; Gomes 2011; Saneian 2012). One study reported outcomes at 1 month and 12 months (Loening-Baucke 2006). However, data for outcomes at 4 weeks were used for meta-analysis. Ratanamongkol 2009 reported median and interquartile ranges for results and these were used to estimate the mean and standard deviation (Hozo 2005).

\section{Efficacy}

Frequency of defecation

Using a random-effects model, there was no statistically significant difference the frequency of defecation (MD 0.20, 95\% CI 0.68 to 1.07$)$. However, there was significant heterogeneity in the pooled analysis $\left(\mathrm{P}=0.03, \mathrm{I}^{2}=66 \%\right)$. A visual inspection of the forest plot suggests that the Saneian 2012 study is the source of this heterogeneity. When this study was excluded in a sensitivity analysis there was a statistically significant result favouring PEG over milk of magnesia and the $\mathrm{I}^{2}$ value dropped to $0 \%$. The MD was 0.69 stools per week (95\% CI, 0.48 to 0.89 ), see Analysis 3.1. The GRADE analysis indicated that the overall quality of the evidence for the primary outcome (frequency of defecation) was low due to sparse data (211 patients) and a high risk of bias (i.e. lack of blinding in one study and lack of blinding, incomplete outcome 
data and selective reporting in the other study) in two studies in the pooled analysis (See Summary of findings 3).

Succesful disimpaction

There was no statistically significant difference in the proportion of participants who were successfully disimpacted. Successful disimpaction was achieved in 100\% (25/25) of PEG patients compared to $96 \%$ (24/25) of milk of magnesia patients (RR 1.04, 95\% CI 0.93 to 1.16). The GRADE analysis indicated that the overall quality of the evidence supporting this outcome was low due to sparse data ( 49 events) and a high risk of bias (i.e. lack of blinding; See Summary of findings 3).

Safety

A serious adverse event of allergy to PEG was reported in one patient (Loening-Baucke 2006). Minor adverse events data were not reported to allow meta-analysis. One study (Ratanamongkol 2009) noted a statistically significant difference in proportion of patients experiencing diarrhoea. Twenty-eight per cent of patients in the milk of magnesia group experienced diarrhoea compared to $4 \%$ of PEG patients ( $\mathrm{P}=0.002)$. Gomes $2011 \mathrm{did}$ not explicitly report adverse event data. Common adverse events reported in the Saneian 2012 study included abdominal pain and bloating in the PEG group and abdominal pain, bloating and diarrhoea in the milk of magnesia group.

\section{PEG versus Enemas}

Bekkali 2009 compared PEG to enemas (90 participants). This study reported outcomes at four weeks.

\section{Efficacy}

Frequency of defecation

There was no statistically significant difference in the frequency of defecation between PEG and enema groups. The MD was 1.00 stools per week (95\% CI -1.58 to 3.58). The GRADE analysis indicated that the overall quality of the evidence for the primary outcome (frequency of defecation) was low due to sparse data (80 patients) and a high risk of bias (i.e. lack of blinding and selective reporting; See Summary of findings 4).

Succesful disimpaction

Successful disimpaction was reported in $80 \%$ (37/46) of enema patients compared to $68 \%$ (30/44) of PEG patients. However, the difference was not statistically significant (RR 0.85, 95\% CI 0.66 to 1.09$)$. The GRADE analysis indicated that the overall quality of the evidence for the primary outcome (frequency of defecation) was low due to sparse data (67 events) and a high risk of bias (i.e. lack of blinding and selective reporting; See Summary of findings 4).

\section{Safety}

Adverse event data were not explicitly reported within this study, although the authors reported significantly higher rates of faecal incontinence and watery stools with PEG.

\section{PEG versus Liquid paraffin}

Three studies (299 participants) compared PEG to liquid paraffin (Tolia 1993; Karami 2009; Rafati 2011). The studies had varying lengths of follow-up. Tolia 1993 followed up patients at two days. Karami 2009 followed patients every week for a month and then monthly for two to four months. Rafati 2011 followed patients weekly for the first two weeks and then monthly until 120 days. The Tolia 1993 study was not pooled with the other two studies because the primary outcome was not similar enough to allow pooling.

\section{Efficacy}

Frequency of defecation

Tolia 1993 reported on the frequency of bowel movements after treatment (scored as $>5,1$ to 5 or none). The authors reported that PEG patients had more frequent bowel movements after treatment than liquid paraffin patients $(\mathrm{P}<0.005)$. Two studies reported on the frequency of defecation at 30 days and were pooled for metaanalysis (Karami 2009; Rafati 2011). There was no statistically significant difference in the frequency of defecation (MD 0.35 , $95 \% \mathrm{CI}-0.24$ to 0.95$)$. The GRADE analysis indicated that the overall quality of the evidence for the primary outcome (frequency of defecation) was very low due to sparse data (261 patients) and a high risk of bias in both studies in the pooled analysis (i.e. lack of blinding and incomplete outcome data in one study and incomplete outcome data and selective reporting in the other study; See Summary of findings 5).

\section{Safety}

No serious adverse events were reported. Tolia 1993 reported significantly more vomiting in the PEG group compared to liquid paraffin $(P<0.005)$. Karami 2009 reported that there were no adverse events. Adverse events reported in the Rafati 2011 study included nausea, vomiting, diarrhoea, flatulence, abdominal pain and dehydration. All of these outcomes, with the exception of diarrhoea, were significantly more likely to occur in children who received liquid paraffin compared to PEG.

\section{PEG versus Flixweed}

One study (109 participants) compared PEG to flixweed ( Nimrouzi 2015). Participants were assessed at three and eight weeks.

\section{Efficacy}

Frequency of defecation

There was no statistically significant difference in the frequency of defecation (MD $0.00,95 \%$ CI -0.33 to 0.33 ). The GRADE analysis indicated that the overall quality of the evidence for the primary outcome (frequency of defecation) was low due to sparse data (109 participants) and a high risk of bias (i.e. lack of blinding and random sequence generation, allocation concealment and incomplete outcome data were also rated as unclear; See Summary of findings 6).

Need for additional therapy 
There was a non-significant trend $(\mathrm{P}=0.05)$ favouring flixweed over PEG for the need for additional therapy. Nineteen per cent (10/53) of PEG participants needed additional therapy compared to $5 \%(3 / 56)$ of flixweed participants (RR 3.52, 95\% CI 1.03 to 12.10). The GRADE analysis indicated that the overall quality of the evidence supporting this outcome was very low due to serious imprecision (13 events) and a high risk of bias (i.e. lack of blinding and random sequence generation, allocation concealment and incomplete outcome data were also rated as unclear; See Summary of findings 6).

\section{Safety}

The authors reported no difference in the proportion of patients who experienced flatulence and abdominal pain after 8 weeks of therapy.

\section{PEG versus dietary fibre mix}

One study (83 participants) compared PEG to dietary fibre mix (Quitadamo 2012). Participants were assessed at one, two, four and eight weeks.

\section{Efficacy}

Frequency of defecation

There was no statistically significant difference in the frequency of defecation (MD $0.20,95 \%$ CI -0.64 to 1.04 ). The GRADE analysis indicated that the overall quality of the evidence for the primary outcome (frequency of defecation) was low due to sparse data (83 participants) and a high risk of bias (i.e. lack of blinding and random sequence generation, allocation concealment and incomplete outcome data were also rated as unclear; See Summary of findings 7).

Need for additional therapy

There was no statistically significant difference in the proportion of participants who required additional therapy for their constipation. Two per cent $(1 / 50)$ of PEG participants required additional therapy compared to $4 \%(2 / 50)$ of dietary fibre participants (RR $0.50,95 \%$ CI 0.05 to 5.34 ). The GRADE analysis indicated that the overall quality of the evidence supporting this outcome was very low due to serious imprecision (3 events) and a high risk of bias (i.e. lack of blinding and random sequence generation, allocation concealment and incomplete outcome data were also rated as unclear; See Summary of findings 7).

Faecal incontinence

There was no statistically significant difference in the frequency of faecal incontinence (MD $-0.10,95 \% \mathrm{CI}-0.62$ to 0.42 ). The GRADE analysis indicated that the overall quality of the evidence supporting this outcome was low due to sparse data (83 participants) and a high risk of bias (i.e. lack of blinding and random sequence generation, allocation concealment and incomplete outcome data were also rated as unclear; See Summary of findings 7).

\section{High dose PEG versus low dose PEG}

One study (90 participants) compared high dose PEG $(0.7 \mathrm{~g} / \mathrm{kg})$ to low dose PEG (0.3 g/kg) (Dziechciarz 2015). Participants were assessed six weeks.

\section{Efficacy}

Frequency of defecation

There was a statistically significant difference in the frequency of defecation favouring high dose over low dose PEG (MD 1.30, 95\% CI 0.76 to 1.84 ). The GRADE analysis indicated that the overall quality of the evidence supporting the primary outcome (frequency of defecation) was low due to sparse data (90 participants) and a high risk of bias (i.e. lack of blinding; See Summary of findings 8).

Need for additional therapy

There was a non-significant trend $(\mathrm{P}=0.06)$ favouring high dose PEG over low dose PEG for the need for additional therapy. Eighteen per cent (8/44) of high dose PEG participants needed additional therapy compared to $37 \%$ (17/46) of low dose PEG participants (RR 0.49 , 95\% CI 0.24 to 1.02 ). The GRADE analysis indicated that the overall quality of the evidence supporting this outcome was very low due to serious imprecision ( 25 events) and a high risk of bias (i.e. lack of blinding; See Summary of findings 8).

Faecal incontinence

There was no statistically significant difference in the proportion of patients who experienced faecal incontinence. Two per cent (1/44) of high dose PEG participants had faecal incontinence compared to $13 \%$ (6/46) of low dose PEG participants (RR 0.17, 95\% CI 0.02 to 1.39 ). The GRADE analysis indicated that the overall quality of the evidence supporting this outcome was very low due to serious imprecision (7 events) and a high risk of bias (i.e. lack of blinding; See Summary of findings 8).

\section{Safety}

Adverse events

There was no statistically significant difference in the proportion of patients who experienced an adverse event. Nine per cent (4/44) of high dose PEG participants had an adverse event compared to 6\% (3/46) of low dose PEG participants (RR 1.39, 95\% CI 0.33 to 5.88). The GRADE analysis indicated that the overall quality of the evidence supporting this outcome was very low due to serious imprecision (7 events) and a high risk of bias (i.e. lack of blinding; See Summary of findings 8). Adverse events in the high dose PEG group included loose stools $(\mathrm{n}=3)$ and refusal of PEG $(\mathrm{n}=1)$. Adverse events in the low dose group included

\section{Liquid Paraffin versus Lactulose}

Two studies (287 participants) compared liquid paraffin to lactulose (Urganci 2005; Farahmand 2007). These studies reported outcomes at eight weeks.

\section{Efficacy}

Frequency of defecation

Using a fixed-effect model, there was a statistically significant result 
favouring liquid paraffin over lactulose. The MD was 4.94 stools per week (95\% CI 4.28 to 5.61) see Analysis 9.1 and Figure 6. There was no evidence of heterogeneity in the pooled analysis ( $P$ $\left.=0.45, \mathrm{I}^{2}=0 \%\right)$. The GRADE analysis indicated that the overall quality of the evidence for the primary outcome (frequency of defecation) was low due to sparse data (287 patients) and a high risk of bias (i.e. lack of blinding in both studies) (See Summary of findings 9).

Figure 6. Forest plot of comparison: 4 Liquid Paraffin versus Lactulose, outcome: 4. I Frequency of defecation.

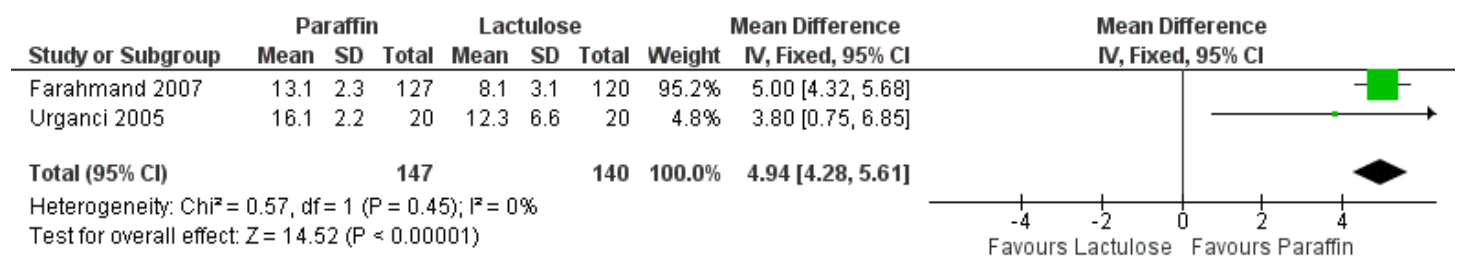

Safety

No serious adverse events were reported in either study. Minor adverse events such as abdominal pain, distention and watery stools were reported with both agents, but data were not presented in a manner to allow meta-analysis.

\section{Lactulose versus Lactitol}

Pitzalis 1995 compared lactulose to lactitol (51 participants), This study reported outcomes at 30 days.

Efficacy

Frequency of defecation

There was no statistically significant difference between the two agents in the frequency of defecation. The MD was -0.80 stools per week (95\% CI -2.63 to 1.03$)$. The GRADE analysis indicated that the overall quality of the evidence for the primary outcome (frequency of defecation) was low due to sparse data ( 42 participants) and a high risk of bias (i.e. selective reporting, random sequence generation, allocation concealment and blinding were also rated as unclear; See Summary of findings 10).

Safety

Adverse events were not reported.

\section{Lactulose versus Milk of Magnesia}

One study (50 participants) also compared lactulose to milk of magnesia (Saneian 2012). Outcomes were measured at five weeks. Efficacy

Frequency of defecation
There was a statistically significant difference in the frequency of defecation favouring milk of magnesia over lactulose (MD $1.51,95 \%$ CI -2.63 to -0.39$)$. The GRADE analysis indicated that the overall quality of the evidence supporting the primary outcome (frequency of defecation) was low due to sparse data (50 participants) and a high risk of bias (i.e. lack of blinding, allocation concealment and incomplete outcome data were also rated as unclear; See Summary of findings 11).

Successful disimpaction

There was no statistically significant difference in the proportion of participants who were successfully disimpacted. Eighty per cent (20/25) of participants in the lactulose group were successfully disimpacted compared to $96 \%(24 / 25)$ of milk of magnesia patients (RR $0.83,95 \%$ CI 0.67 to 1.03 ). The GRADE analysis indicated that the overall quality of the evidence supporting this outcome was low due to sparse data ( 44 events) and a high risk of bias (i.e. lack of blinding, allocation concealment and incomplete outcome data were also rated as unclear; See Summary of findings 11). Need for additional therapy

There was no statistically significant difference in the proportion of participants who needed additional therapy for their constipation. Forty per cent $(10 / 25)$ of participants in the lactulose group required additional therapy compared to $20 \%(5 / 25)$ of milk of magnesia patients (RR 2.00, 95\% CI 0.80 to 5.02). The GRADE analysis indicated that the overall quality of the evidence supporting this outcome was very low due to sparse data ( 15 events) and a high risk of bias (i.e. lack of blinding: See Summary of findings 11).

Osmotic and stimulant laxatives for the management of childhood constipation (Review)

Copyright @ 2016 The Cochrane Collaboration. Published by John Wiley \& Sons, Ltd. 
Safety

Adverse events

Common adverse events reported in the Saneian 2012 study included abdominal pain, bloating and diarrhoea in the milk of magnesia group and abdominal pain and bloating in the lactulose group.

\section{Lactulose versus Partially Hydrolyzed Guar Gum}

One study (61 participants) compared lactulose to partially hydrolyzed guar gum (Ustundag 2010). Outcomes were measured at four weeks.

\section{Efficacy}

Frequency of defecation

There was no statistically significant difference in the frequency of defecation (MD 1.00, 95\% CI -1.80 to 3.80). The GRADE analysis indicated that the overall quality of the evidence supporting the primary outcome (frequency of defecation) was low due to sparse data (61 participants) and an unclear risk of bias (i.e. random sequence generation, allocation concealment, blinding and selective reporting were rated as unclear; See Summary of findings 12).

\section{Safety}

Adverse events

Flatulence was reported in the lactulose group (Ustundag 2010).

\section{Dietary fibre mix versus Lactulose}

Kokke 2008 compared dietary fibre to lactulose (125 participants). This study reported outcomes at eight weeks.

Efficacy
Frequency of defecation

Kokke 2008 reported that there was no statistically significant difference in the frequency of defecation between the two agents at eight weeks (mean 7 stools per week in the fibre group versus 6 stools per week in the lactulose group; $\mathrm{P}=0.481$ ).

Safety

The authors reported no serious or significant adverse effects. There were three cases of diarrhoea (one in the fibre mixture group and two in the lactulose group).

\section{Senna versus Lactulose}

One crossover study (Perkin 1977), compared senna with lactulose (21 participants),

\section{Efficacy}

Passage of stool

There was no statistically significant difference between the two agents in the number of patients passing stools of any kind each day.

\section{Safety}

No serious or significant adverse effects were reported in the two study groups. Minor adverse events such as colic or diarrhoea, were more commonly seen in the senna group.

\section{Subgroup and sensitivity analyses}

GIven the heterogenous nature of the included studies, further subgroup or sensitivity analyses were not completed.

\section{Publication Bias}

Publication bias was not investigated as there were not enough studies in any of the pooled analyses to construct a reliable funnel plot. 


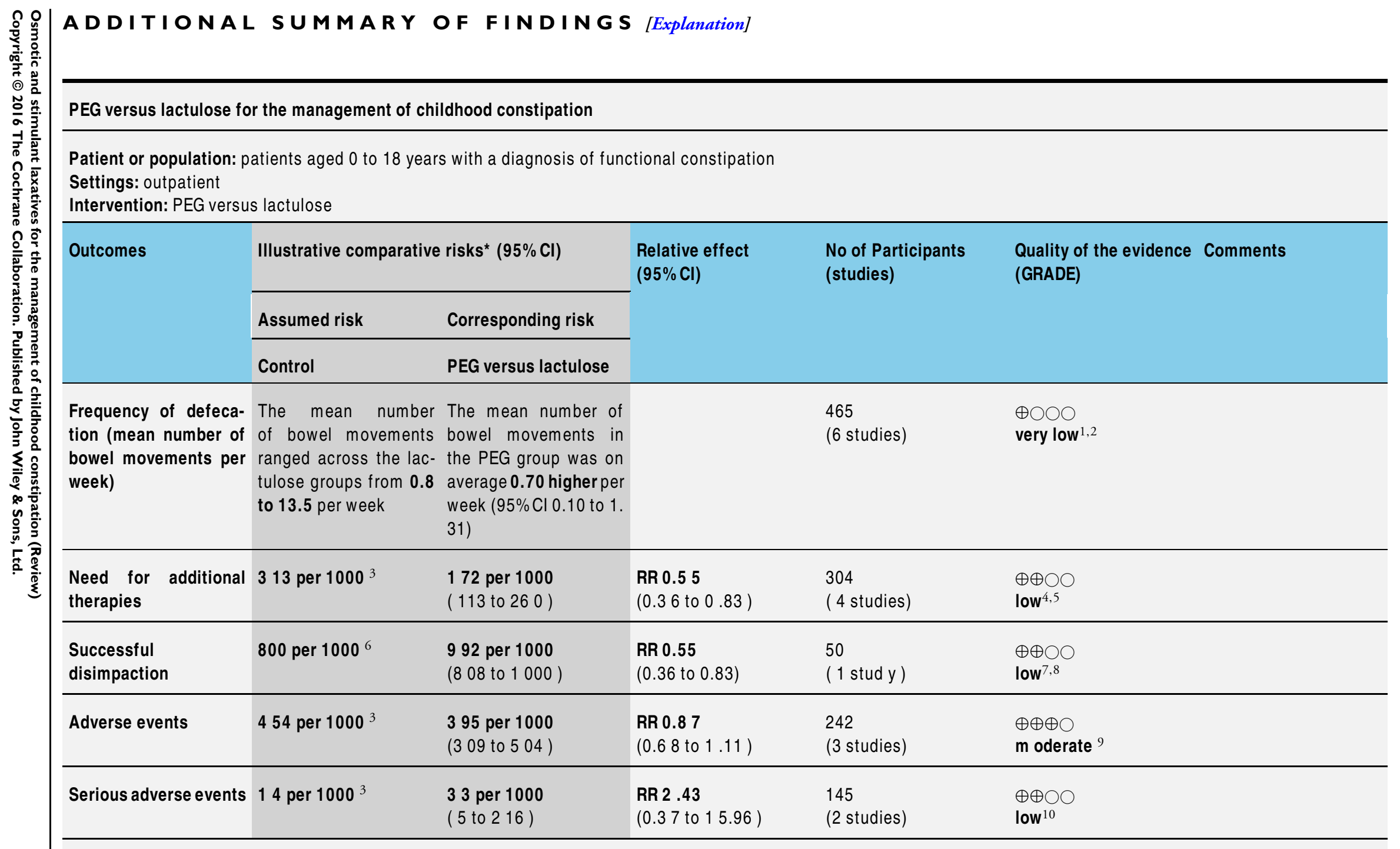

* The basis for the assumed risk (e.g. the median control group risk across studies) is provided in footnotes. The corresponding risk (and its $95 \%$ confidence interval) is based on the assumed risk in the comparison group and the relative effect of the intervention (and its $95 \% \mathrm{Cl}$ ).

Cl: Confidence interval; 
GRADE Working Group grades of evidence

High quality: Further research is very unlikely to change our confidence in the estimate of effect.

Moderate quality: Further research is likely to have an important impact on our confidence in the estimate of effect and may change the estimate.

Low quality: Further research is very likely to have an important impact on our confidence in the estimate of effect and is likely to change the estimate.

Very low quality: We are very uncertain about the estimate.

${ }^{1}$ Downgraded two levels due to serious Inconsistency (high statistical heterogeneity $\mathrm{I}^{2}=69 \% ; P=0.007$ )

2 Downgraded one level due to high risk of bias in two studies in the pooled analysis (i.e. lack of blinding and selective

reporting).

${ }^{3}$ Control group risk comes from control arm of meta-analysis, based on included trials.

${ }^{4}$ Downgraded one level due to high risk of bias in one study in the pooled analysis (i.e. lack of blinding).

${ }^{5}$ Downgraded one level due to sparse data (74 events).

${ }^{6}$ Control group risk comes from control arm of the included study.

${ }^{7}$ Downgraded one level due to high risk of bias (i.e. lack of blinding).

${ }^{8}$ Downgraded one level due to sparse data (45 events).

9 Downgraded one level due to sparse data (100 events).

${ }^{10}$ Downgraded two levels due to very sparse data (4 events). 
PEG versus milk of magnesia (MOM) for the management of childhood constipation

Patient or population: patients aged 0 to 18 years with a diagnosis of functional constipation

Settings: outpatient

Intervention: PEG versus MOM

\begin{tabular}{|c|c|c|c|c|c|}
\hline \multirow[t]{3}{*}{ Outcomes } & \multicolumn{2}{|c|}{ Illustrative comparative risks* $(95 \% \mathrm{Cl})$} & \multirow{3}{*}{$\begin{array}{l}\text { Relative effect } \\
(95 \% \mathrm{Cl})\end{array}$} & \multirow{3}{*}{$\begin{array}{l}\text { No of Participants } \\
\text { (studies) }\end{array}$} & \multirow{3}{*}{$\begin{array}{l}\text { Quality of the evidence Comment } \\
\text { (GRADE) }\end{array}$} \\
\hline & Assumed risk & Corresponding risk & & & \\
\hline & Control & PEG versus $M O M$ & & & \\
\hline $\begin{array}{l}\text { Frequency of defeca- } \\
\text { tion (mean number of } \\
\text { bowel movements per } \\
\text { week) }\end{array}$ & $\begin{array}{l}\text { The mean number } \\
\text { of bowel movements } \\
\text { ranged across the MOM } \\
\text { groups from } 4.3 \text { to } 9.7 \\
\text { per week }\end{array}$ & $\begin{array}{l}\text { The mean number of } \\
\text { bowel movements in } \\
\text { the PEG group was on } \\
\text { average } 0.69 \text { higher per } \\
\text { week }(95 \% \mathrm{Cl} 0.48 \text { to } 0 \text {. } \\
\text { 89) }\end{array}$ & & $\begin{array}{l}211 \\
\text { (3 studies) }\end{array}$ & $\begin{array}{l}\oplus \oplus \bigcirc \bigcirc \\
\text { low }^{1,2}\end{array}$ \\
\hline $\begin{array}{l}\text { Successful } \\
\text { disimpaction }\end{array}$ & 960 per $1000^{3}$ & $\begin{array}{l}998 \text { per } 1000 \\
(893 \text { to } 1000)\end{array}$ & $\begin{array}{l}\text { RR } 1.04 \\
(0.93 \text { to } 1.16)\end{array}$ & $\begin{array}{l}50 \\
(1 \text { stud } y)\end{array}$ & $\begin{array}{l}\oplus \oplus \bigcirc \bigcirc \\
\text { low }^{4,5}\end{array}$ \\
\hline
\end{tabular}

* The basis for the assumed risk (e.g. the median control group risk across studies) is provided in footnotes. The corresponding risk (and its $95 \%$ confidence interval) is based on the assumed risk in the comparison group and the relative effect of the intervention (and its $95 \% \mathrm{Cl}$ ).

Cl: Confidence interval;

GRADE Working Group grades of evidence

High quality: Further research is very unlikely to change our confidence in the estimate of effect.

Moderate quality: Further research is likely to have an important impact on our confidence in the estimate of effect and may change the estimate.

Low quality: Further research is very likely to have an important impact on our confidence in the estimate of effect and is likely to change the estimate.

Very low quality: We are very uncertain about the estimate.

${ }^{1}$ Downgraded one level due to sparse data (211 patients).

${ }^{2}$ Downgraded one level due to high risk of bias in two studies in pooled analysis (i.e. lack of blinding in one study and lack of

blinding, incomplete outcome data and selective reporting in the other study).

${ }^{3}$ Control group risk comes from control arm of the included study. 


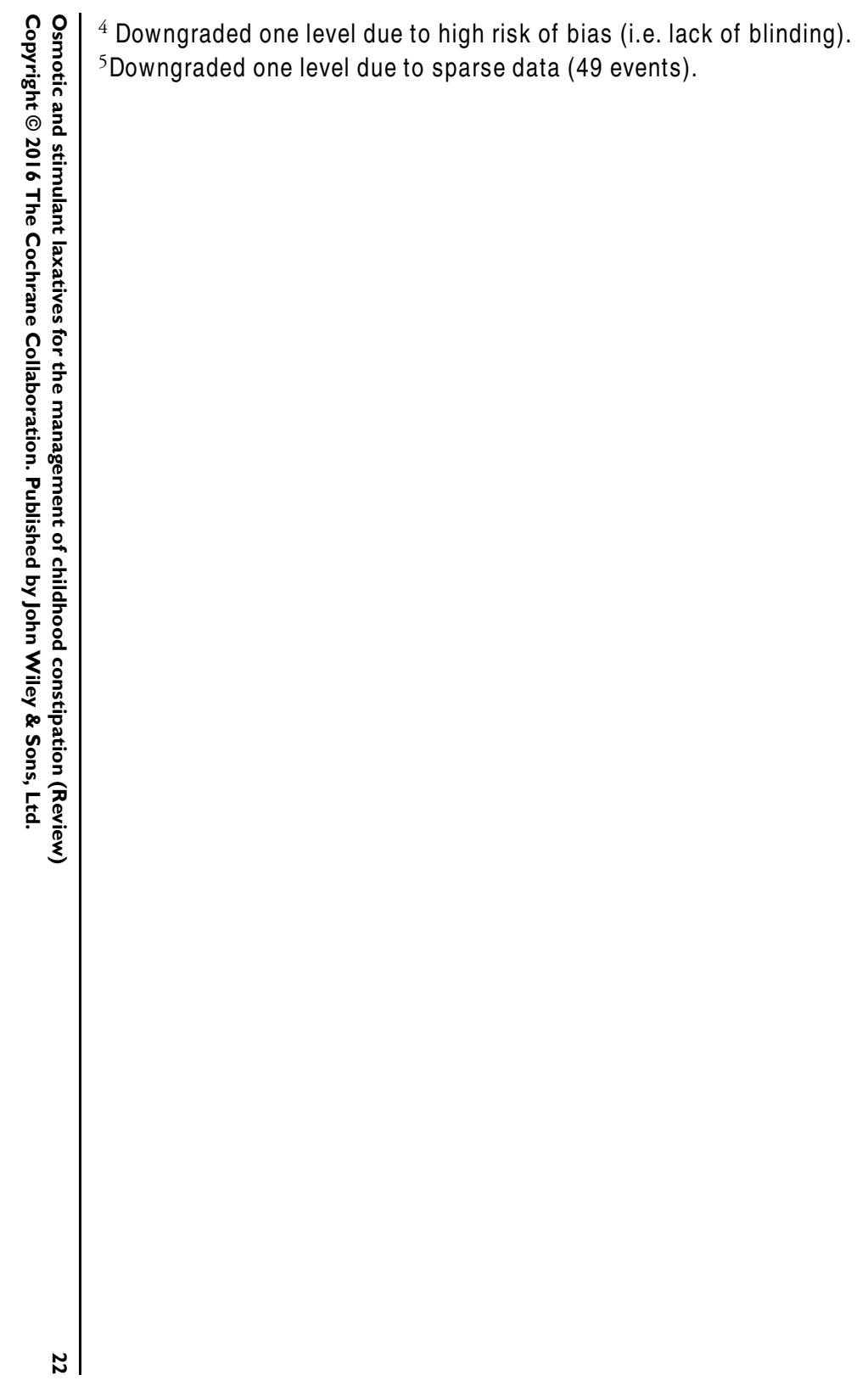




\section{PEG versus enema for the management of childhood constipation}

Patient or population: patients aged 0 to 18 years with a diagnosis of functional constipation

Settings: outpatient

Intervention: PEG versus enema

\begin{tabular}{|c|c|c|c|c|c|}
\hline \multirow[t]{3}{*}{ Outcomes } & \multicolumn{2}{|c|}{ Illustrative comparative risks ${ }^{*}(95 \% \mathrm{Cl})$} & \multirow{3}{*}{$\begin{array}{l}\text { Relative effect } \\
(95 \% \mathrm{Cl})\end{array}$} & \multirow{3}{*}{$\begin{array}{l}\text { No of Participants } \\
\text { (studies) }\end{array}$} & \multirow{3}{*}{$\begin{array}{l}\text { Quality of the evidence Comments } \\
\text { (GRADE) }\end{array}$} \\
\hline & Assumed risk & Corresponding risk & & & \\
\hline & Control & PEG versus enema & & & \\
\hline $\begin{array}{l}\text { Frequency of defeca- } \\
\text { tion (mean number of } \\
\text { bowel movements per } \\
\text { week) }\end{array}$ & $\begin{array}{l}\text { The mean number of } \\
\text { bowel movements in } \\
\text { the enema group was } 7 \text {. } \\
7 \text { per week }\end{array}$ & $\begin{array}{l}\text { The mean number of } \\
\text { bowel movements in } \\
\text { the PEG group was on } \\
\text { average } 1.0 \text { higher per } \\
\text { week }(95 \% \mathrm{Cl}-1.58 \text { to } \\
3.58)\end{array}$ & & $\begin{array}{l}80 \\
(1 \text { study })\end{array}$ & $\begin{array}{l}\oplus \oplus \bigcirc \bigcirc \\
\text { low }^{1,2}\end{array}$ \\
\hline $\begin{array}{l}\text { S uccessful disim- } \\
\text { paction }\end{array}$ & 804 per $1000^{3}$ & $\begin{array}{l}684 \text { per } 1000 \\
(531 \text { to } 877)\end{array}$ & $\begin{array}{l}\text { RR } 0.85 \\
(0.66 \text { to } 1.51)\end{array}$ & $\begin{array}{l}90 \\
\text { (1 study) }\end{array}$ & $\begin{array}{l}\oplus \oplus \bigcirc \bigcirc \\
\text { low }^{2,4}\end{array}$ \\
\hline
\end{tabular}

* The basis for the assumed risk (e.g. the median control group risk across studies) is provided in footnotes. The corresponding risk (and its $95 \%$ confidence interval) is based on the assumed risk in the comparison group and the relative effect of the intervention (and its $95 \% \mathrm{Cl}$ ).

Cl: Confidence interval;

GRADE Working Group grades of evidence

High quality: Further research is very unlikely to change our confidence in the estimate of effect.

Moderate quality: Further research is likely to have an important impact on our confidence in the estimate of effect and may change the estimate.

Low quality: Further research is very likely to have an important impact on our confidence in the estimate of effect and is likely to change the estimate.

Very low quality: We are very uncertain about the estimate.

${ }^{1}$ Downgraded one level due to sparse data (80 patients).

2 Downgraded one level due to high risk of bias (i.e. lack of blinding and selective reporting).

${ }^{3}$ Control group risk comes from control arm of the included study.

${ }^{4}$ Downgraded one level due to sparse data ( 67 patients). 


\section{PEG versus paraffin for the management of childhood constipation}

Patient or population: patients aged 0 to 18 years with a diagnosis of functional constipation

Settings: outpatient

Intervention: PEG versus paraffin

\begin{tabular}{l} 
Outcomes \\
\cline { 2 - 3 }
\end{tabular}

GRADE Working Group grades of evidence

High quality: Further research is very unlikely to change our confidence in the estimate of effect.

Moderate quality: Further research is likely to have an important impact on our confidence in the estimate of effect and may change the estimate.

Low quality: Further research is very likely to have an important impact on our confidence in the estimate of effect and is likely to change the estimate.

Very low quality: We are very uncertain about the estimate.

${ }^{1}$ Downgraded one level due to sparse data (261 patients).

2 Downgraded two levels due to high risk of bias in both studies (i.e. lack of blinding, incomplete outcome data and selective

reporting). 


\section{PEG versus flixweed for the management of childhood constipation}

Patient or population: patients aged 0 to 18 years with a diagnosis of functional constipation

Settings: outpatient

Intervention: PEG versus flixweed

\begin{tabular}{|c|c|c|c|c|c|}
\hline \multirow[t]{3}{*}{ Outcomes } & \multicolumn{2}{|c|}{ Illustrative comparative risks ${ }^{*}(95 \% \mathrm{Cl})$} & \multirow{3}{*}{$\begin{array}{l}\text { Relative effect } \\
(95 \% \mathrm{Cl})\end{array}$} & \multirow{3}{*}{$\begin{array}{l}\text { No of Participants } \\
\text { (studies) }\end{array}$} & \multirow{3}{*}{$\begin{array}{l}\text { Quality of the evidence Comments } \\
\text { (GRADE) }\end{array}$} \\
\hline & Assumed risk & Corresponding risk & & & \\
\hline & Control & PEG versus flixweed & & & \\
\hline $\begin{array}{l}\text { Frequency of defeca- } \\
\text { tion (mean number of } \\
\text { bowel movements per } \\
\text { week) }\end{array}$ & $\begin{array}{l}\text { The mean number of } \\
\text { bowel movements in } \\
\text { the flixweed group was } \\
5 \text { per week }\end{array}$ & $\begin{array}{l}\text { The mean number of } \\
\text { bowel movements in } \\
\text { the PEG group was on } \\
\text { average } 0.00 \text { higher per } \\
\text { week }(95 \% \mathrm{Cl}-0.33 \text { to } \\
0.33)\end{array}$ & & $\begin{array}{l}109 \\
\text { (1 study) }\end{array}$ & $\begin{array}{l}\oplus \oplus \bigcirc \bigcirc \\
\text { low }^{1,2}\end{array}$ \\
\hline $\begin{array}{l}\text { Need for additional } \\
\text { therapies }\end{array}$ & 54 per $1000^{3}$ & $\begin{array}{l}189 \text { per } 1000 \\
(55 \text { to } 648)\end{array}$ & $\begin{array}{l}\text { RR } 3.52 \\
(1.03 \text { to } 12.10)\end{array}$ & $\begin{array}{l}109 \\
\text { (1 study) }\end{array}$ & $\begin{array}{l}\oplus \bigcirc \bigcirc \bigcirc \\
\text { very low } 2,4\end{array}$ \\
\hline
\end{tabular}

*The basis for the assumed risk (e.g. the median control group risk across studies) is provided in footnotes. The corresponding risk (and its $95 \%$ confidence interval) is based on the assumed risk in the comparison group and the relative effect of the intervention (and its $95 \% \mathrm{Cl}$ ).

Cl: Confidence interval;

GRADE Working Group grades of evidence

High quality: Further research is very unlikely to change our confidence in the estimate of effect.

Moderate quality: Further research is likely to have an important impact on our confidence in the estimate of effect and may change the estimate.

Low quality: Further research is very likely to have an important impact on our confidence in the estimate of effect and is likely to change the estimate.

Very low quality: We are very uncertain about the estimate.

${ }^{1}$ Downgraded one level due to sparse data (109 patients).

2 Downgraded one level due to high risk of bias (i.e. lack of blinding). Random sequence generation, allocation concealment

and incomplete outcome data were rated as unclear risk of bias.

${ }^{3}$ Control group risk comes from control arm of the included study. 


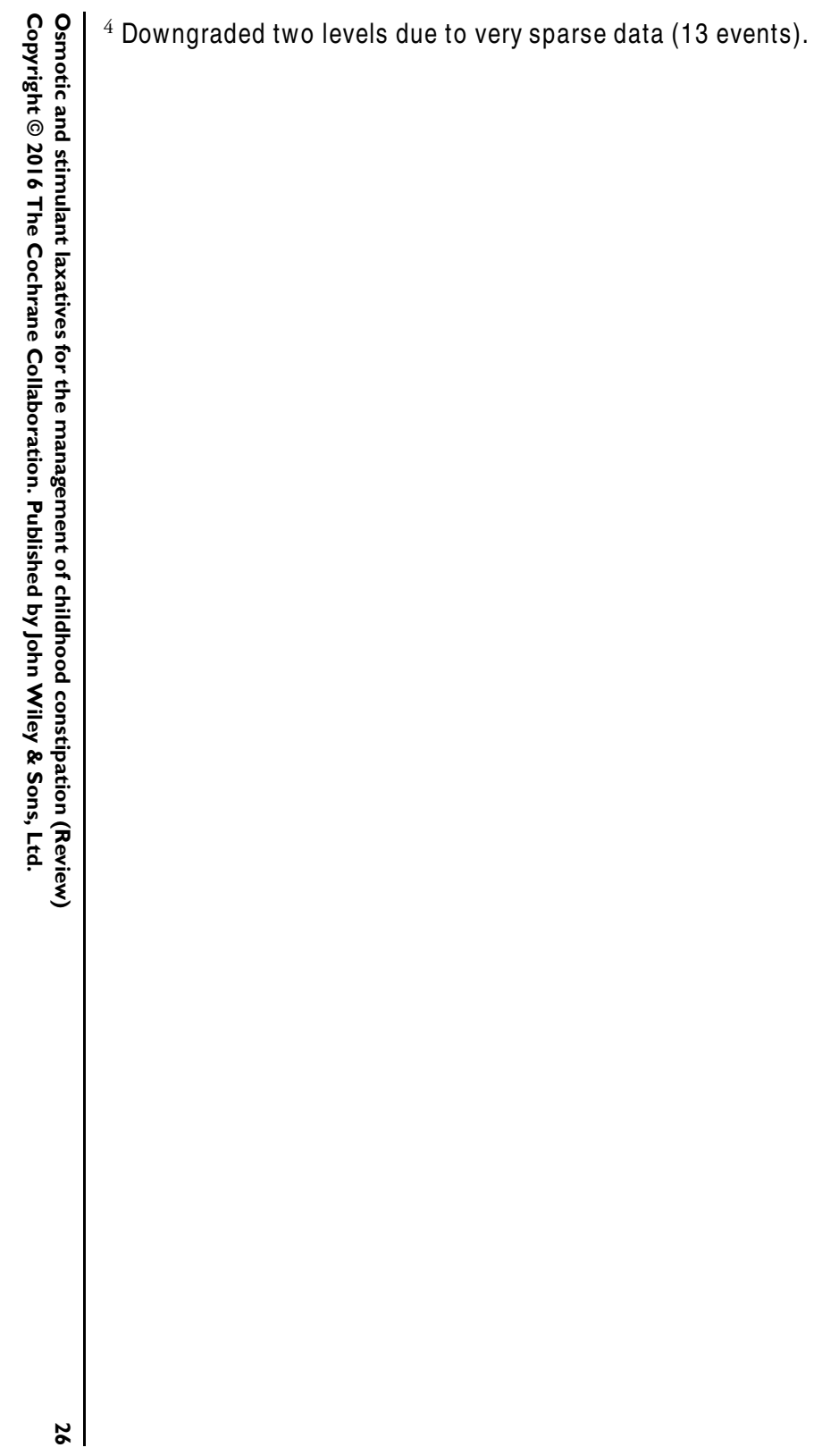




\section{PEG versus dietary fibre for the management of childhood constipation}

Patient or population: patients aged 0 to 18 years with a diagnosis of functional constipation

Settings: outpatient

Intervention: PEG versus dietary fibre

\begin{tabular}{|c|c|c|c|c|c|}
\hline \multirow[t]{3}{*}{ Outcomes } & \multicolumn{2}{|c|}{ Illustrative comparative risks* $(95 \% \mathrm{Cl})$} & \multirow{3}{*}{$\begin{array}{l}\text { Relative effect } \\
(95 \% \mathrm{Cl})\end{array}$} & \multirow{3}{*}{$\begin{array}{l}\text { No of Participants } \\
\text { (studies) }\end{array}$} & \multirow{3}{*}{$\begin{array}{l}\text { Quality of the evidence Comments } \\
\text { (GRADE) }\end{array}$} \\
\hline & Assumed risk & Corresponding risk & & & \\
\hline & Control & $\begin{array}{l}\text { PEG versus dietary fi- } \\
\text { bre }\end{array}$ & & & \\
\hline $\begin{array}{l}\text { Frequency of defeca- } \\
\text { tion (mean number of } \\
\text { bowel movements per } \\
\text { week) }\end{array}$ & $\begin{array}{l}\text { The mean number of } \\
\text { bowel movements in } \\
\text { the dietary fibre group } \\
\text { was } 5.6 \text { per week }\end{array}$ & $\begin{array}{l}\text { The mean number of } \\
\text { bowel movements in } \\
\text { the PEG group was on } \\
\text { average } 0.20 \text { higher per } \\
\text { week }(95 \% \mathrm{Cl}-0.64 \text { to } \\
1.04)\end{array}$ & & $\begin{array}{l}83 \\
\text { (1 study) }\end{array}$ & $\begin{array}{l}\oplus \oplus \bigcirc \bigcirc \\
\text { low }^{1,2}\end{array}$ \\
\hline $\begin{array}{l}\text { Need for additional } \\
\text { therapies }\end{array}$ & 40 per $1000^{3}$ & $\begin{array}{l}20 \text { per } 1000 \\
(2 \text { to } 214)\end{array}$ & $\begin{array}{l}\text { RR } 0.50 \\
(0.05 \text { to } 5.34)\end{array}$ & $\begin{array}{l}100 \\
\text { (1 study) }\end{array}$ & $\begin{array}{l}\oplus \oplus \bigcirc \bigcirc \\
\text { very low } 2,4\end{array}$ \\
\hline $\begin{array}{l}\text { Frequency of faecal in- } \\
\text { continence }\end{array}$ & $\begin{array}{l}\text { The mean number } \\
\text { of faecal incontinence } \\
\text { episodes in the dietary } \\
\text { fibre group was } 0.3 \text { per } \\
\text { week }\end{array}$ & $\begin{array}{l}\text { The mean number } \\
\text { of faecal incontinence } \\
\text { episodes in the PEG } \\
\text { group was on average } \\
-0.10 \text { lower per week } \\
(95 \% \mathrm{Cl}-0.62 \text { to } 0.42)\end{array}$ & & $\begin{array}{l}83 \\
\text { (1 study) }\end{array}$ & $\begin{array}{l}\oplus \oplus \bigcirc \bigcirc \\
\text { low }^{1,2}\end{array}$ \\
\hline
\end{tabular}

* The basis for the assumed risk (e.g. the median control group risk across studies) is provided in footnotes. The corresponding risk (and its $95 \%$ confidence interval) is based on the assumed risk in the comparison group and the relative effect of the intervention (and its $95 \% \mathrm{Cl}$ ).

Cl: Confidence interval; 
GRADE Working Group grades of evidence

High quality: Further research is very unlikely to change our confidence in the estimate of effect.

Moderate quality: Further research is likely to have an important impact on our confidence in the estimate of effect and may change the estimate.

Low quality: Further research is very likely to have an important impact on our confidence in the estimate of effect and is likely to change the estimate.

Very low quality: We are very uncertain about the estimate.

Downgraded one level due to sparse data (83 patients).

2 Downgraded one level due to high risk of bias (i.e. lack of blinding). Random sequence generation, allocation concealment

and incomplete outcome data were rated as unclear risk of bias.

${ }^{3}$ Control group risk comes from control arm of the included study.

${ }^{4}$ Downgraded two levels due to very sparse data (3 events). 


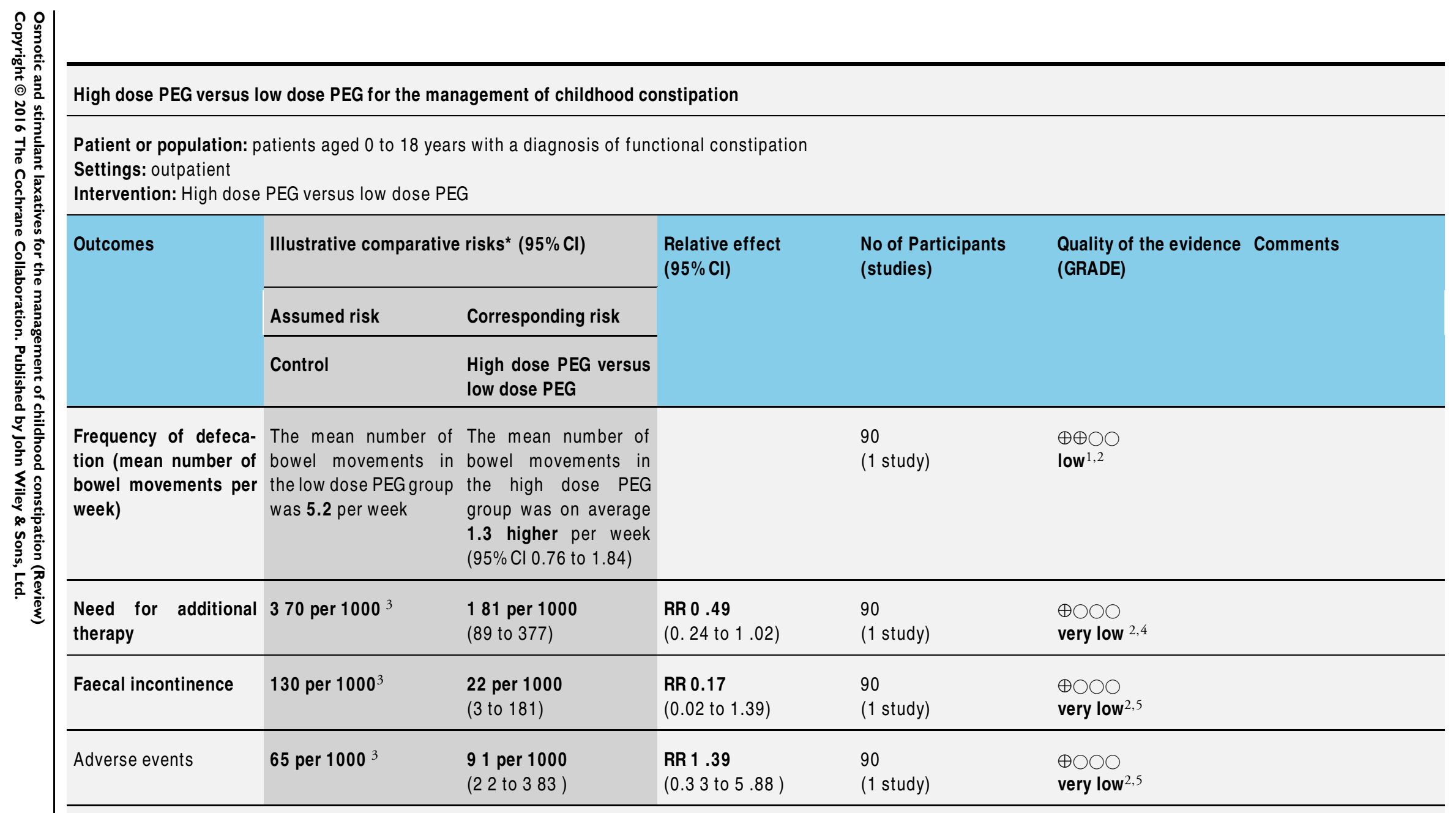

*The basis for the assumed risk (e.g. the median control group risk across studies) is provided in footnotes. The corresponding risk (and its $95 \%$ confidence interval) is based on the assumed risk in the comparison group and the relative effect of the intervention (and its $95 \% \mathrm{Cl}$ ).

Cl: Confidence interval; 
GRADE Working Group grades of evidence

High quality: Further research is very unlikely to change our confidence in the estimate of effect.

Moderate quality: Further research is likely to have an important impact on our confidence in the estimate of effect and may change the estimate.

Low quality: Further research is very likely to have an important impact on our confidence in the estimate of effect and is likely to change the estimate.

Very low quality: We are very uncertain about the estimate.

Downgraded one level due to sparse data (90 patients).

${ }^{2}$ Downgraded one level due to high risk of bias (i.e. lack of blinding).

${ }^{3}$ Control group risk comes from control arm of the included study.

${ }^{4}$ Downgraded two levels due to very sparse data (25 events).

${ }^{5}$ Downgraded two levels due to very sparse data (7 events). 
Liquid paraffin (mineral oil) versus lactulose for the management of childhood constipation

Patient or population: patients aged 0 to 18 years with a diagnosis of functional constipation

Settings: outpatient

Intervention: Liquid paraffin (mineral oil) versus lactulose

\begin{tabular}{|c|c|c|c|c|c|}
\hline \multirow[t]{3}{*}{ Outcomes } & \multicolumn{2}{|c|}{ Illustrative comparative risks* $(95 \% \mathrm{Cl})$} & \multirow{3}{*}{$\begin{array}{l}\text { Relative effect } \\
(95 \% \mathrm{Cl})\end{array}$} & \multirow{3}{*}{$\begin{array}{l}\text { No of Participants } \\
\text { (studies) }\end{array}$} & \multirow{3}{*}{$\begin{array}{l}\text { Quality of the evidence Comments } \\
\text { (GRADE) }\end{array}$} \\
\hline & Assumed risk & Corresponding risk & & & \\
\hline & Control & PEG versus lactulose & & & \\
\hline $\begin{array}{l}\text { Frequency of defeca- } \\
\text { tion (mean number of } \\
\text { bowel movements per } \\
\text { week) }\end{array}$ & $\begin{array}{l}\text { The mean number } \\
\text { of bowel movements } \\
\text { ranged across the lac- } \\
\text { tulose groups from } 8.1 \\
\text { to } 12.3 \text { per week }\end{array}$ & $\begin{array}{l}\text { The mean number of } \\
\text { bowel movements in } \\
\text { the PEG group was on } \\
\text { average } 4.94 \text { higher per } \\
\text { week }(95 \% \mathrm{Cl} 4.28 \text { to } 5 \text {. } \\
61 \text { ) }\end{array}$ & & $\begin{array}{l}287 \\
\text { (2 studies) }\end{array}$ & $\begin{array}{l}\oplus \oplus \bigcirc \bigcirc \\
\text { low }^{1,2}\end{array}$ \\
\hline
\end{tabular}

* The basis for the assumed risk (e.g. the median control group risk across studies) is provided in footnotes. The corresponding risk (and its $95 \%$ confidence interval) is based on the assumed risk in the comparison group and the relative effect of the intervention (and its $95 \% \mathrm{Cl}$ ).

Cl: Confidence interval;

GRADE Working Group grades of evidence

High quality: Further research is very unlikely to change our confidence in the estimate of effect.

Moderate quality: Further research is likely to have an important impact on our confidence in the estimate of effect and may change the estimate.

Low quality: Further research is very likely to have an important impact on our confidence in the estimate of effect and is likely to change the estimate.

Very low quality: We are very uncertain about the estimate.

${ }^{1}$ Downgraded one level due to sparse data (287 patients).

${ }^{2}$ Downgraded one l evel due to high risk of bias in two studies in pooled analysis (i.e. lack of blinding ). 
Lactulose versus lactitol for the management of childhood constipation

Patient or population: patients aged 0 to 18 years with a diagnosis of functional constipation

Settings: outpatient

Intervention: Lactulose versus lactitol

\begin{tabular}{|c|c|c|c|c|c|}
\hline \multirow[t]{3}{*}{ Outcomes } & \multicolumn{2}{|c|}{ Illustrative comparative risks* $(95 \% \mathrm{Cl})$} & \multirow{3}{*}{$\begin{array}{l}\text { Relative effect } \\
(95 \% \mathrm{Cl})\end{array}$} & \multirow{3}{*}{$\begin{array}{l}\text { No of Participants } \\
\text { (studies) }\end{array}$} & \multirow{3}{*}{$\begin{array}{l}\text { Quality of the evidence Comments } \\
\text { (GRADE) }\end{array}$} \\
\hline & Assumed risk & Corresponding risk & & & \\
\hline & Control & $\begin{array}{l}\text { Lactulose versus lacti- } \\
\text { tol }\end{array}$ & & & \\
\hline $\begin{array}{l}\text { Frequency of defeca- } \\
\text { tion (mean number of } \\
\text { bowel movements per } \\
\text { week) }\end{array}$ & $\begin{array}{l}\text { The mean number of } \\
\text { bowel movements in } \\
\text { the lactitol group was } \\
5.6 \text { per week }\end{array}$ & $\begin{array}{l}\text { The mean number of } \\
\text { bowel movements in } \\
\text { the lactulose group was } \\
\text { on average } 0.8 \text { lower } \\
\text { per week }(95 \% \mathrm{Cl}-2.63 \\
\text { to } 1.03 \text { ) }\end{array}$ & & $\begin{array}{l}42 \\
\text { (1 study) }\end{array}$ & $\begin{array}{l}\oplus \oplus \bigcirc \bigcirc \\
\text { low }^{1,2}\end{array}$ \\
\hline
\end{tabular}

GRADE Working Group grades of evidence

High quality: Further research is very unlikely to change our confidence in the estimate of effect.

Moderate quality: Further research is likely to have an important impact on our confidence in the estimate of effect and may change the estimate.

Low quality: Further research is very likely to have an important impact on our confidence in the estimate of effect and is likely to change the estimate.

Very low quality: We are very uncertain about the estimate.

${ }^{1}$ Downgraded one level due to sparse data (42 patients).

${ }^{2}$ Downgraded one level due to high risk of bias (i.e. selective reporting). Random sequence generation, allocation concealment

and blinding were rated as unclear risk of bias. 
Lactulose versus milk of magnesia (MOM) for the management of childhood constipation

Patient or population: patients aged 0 to 18 years with a diagnosis of functional constipation

Settings: outpatient

Intervention: Lactulose versus milk of magnesia (MOM)

\begin{tabular}{|c|c|c|c|c|c|}
\hline \multirow[t]{3}{*}{ Outcomes } & \multicolumn{2}{|c|}{ Illustrative comparative risks* $(95 \% \mathrm{Cl})$} & \multirow{3}{*}{$\begin{array}{l}\text { Relative effect } \\
(95 \% \mathrm{Cl})\end{array}$} & \multirow{3}{*}{$\begin{array}{l}\text { No of Participants } \\
\text { (studies) }\end{array}$} & \multirow{3}{*}{$\begin{array}{l}\text { Quality of the evidence Comments } \\
\text { (GRADE) }\end{array}$} \\
\hline & Assumed risk & Corresponding risk & & & \\
\hline & Control & Lactulose versus M OM & & & \\
\hline $\begin{array}{l}\text { Frequency of defeca- } \\
\text { tion (mean number of } \\
\text { bowel movements per } \\
\text { week) }\end{array}$ & $\begin{array}{l}\text { The mean number of } \\
\text { bowel movements in } \\
\text { the MOM group was } 4 \text {. } \\
7 \text { per week }\end{array}$ & $\begin{array}{l}\text { The mean number of } \\
\text { bowel movements in } \\
\text { the lactulose group was } \\
\text { on average } 1.51 \text { lower } \\
\text { per week ( } 95 \% \mathrm{Cl}-2.63 \\
\text { to }-0.39 \text { ) }\end{array}$ & & $\begin{array}{l}50 \\
\text { (1 study) }\end{array}$ & $\begin{array}{l}\oplus \oplus \bigcirc \bigcirc \\
\text { low }^{1,2}\end{array}$ \\
\hline $\begin{array}{l}\text { Successful } \\
\text { disimpaction }\end{array}$ & 960 per $1000^{3}$ & $\begin{array}{l}797 \text { per } 1000 \\
(643 \text { to } 989)\end{array}$ & $\begin{array}{l}\operatorname{RR} 0.83 \\
(0.67 \text { to } 1.03)\end{array}$ & $\begin{array}{l}50 \\
\text { (1 study) }\end{array}$ & $\begin{array}{l}\oplus \oplus \bigcirc \bigcirc \\
\text { low }^{2,4}\end{array}$ \\
\hline $\begin{array}{l}\text { Need for additional } \\
\text { therapies }\end{array}$ & 200 per $1000^{3}$ & $\begin{array}{l}400 \text { per } 1000 \\
(160 \text { to } 1000)\end{array}$ & $\begin{array}{l}\text { RR } 2.00 \\
(0.80 \text { to } 5.02)\end{array}$ & $\begin{array}{l}50 \\
(1 \text { study })\end{array}$ & $\begin{array}{l}\oplus \bigcirc \bigcirc \bigcirc \\
\text { very low } 2,5\end{array}$ \\
\hline
\end{tabular}

* The basis for the assumed risk (e.g. the median control group risk across studies) is provided in footnotes. The corresponding risk (and its $95 \%$ confidence interval) is based on the assumed risk in the comparison group and the relative effect of the intervention (and its $95 \% \mathrm{Cl}$ ).

Cl: Confidence interval;

GRADE Working Group grades of evidence

High quality: Further research is very unlikely to change our confidence in the estimate of effect.

Moderate quality: Further research is likely to have an important impact on our confidence in the estimate of effect and may change the estimate.

Low quality: Further research is very likely to have an important impact on our confidence in the estimate of effect and is likely to change the estimate.

Very low quality: We are very uncertain about the estimate.

${ }^{1}$ Downgraded one level due to sparse data (50 patients). 


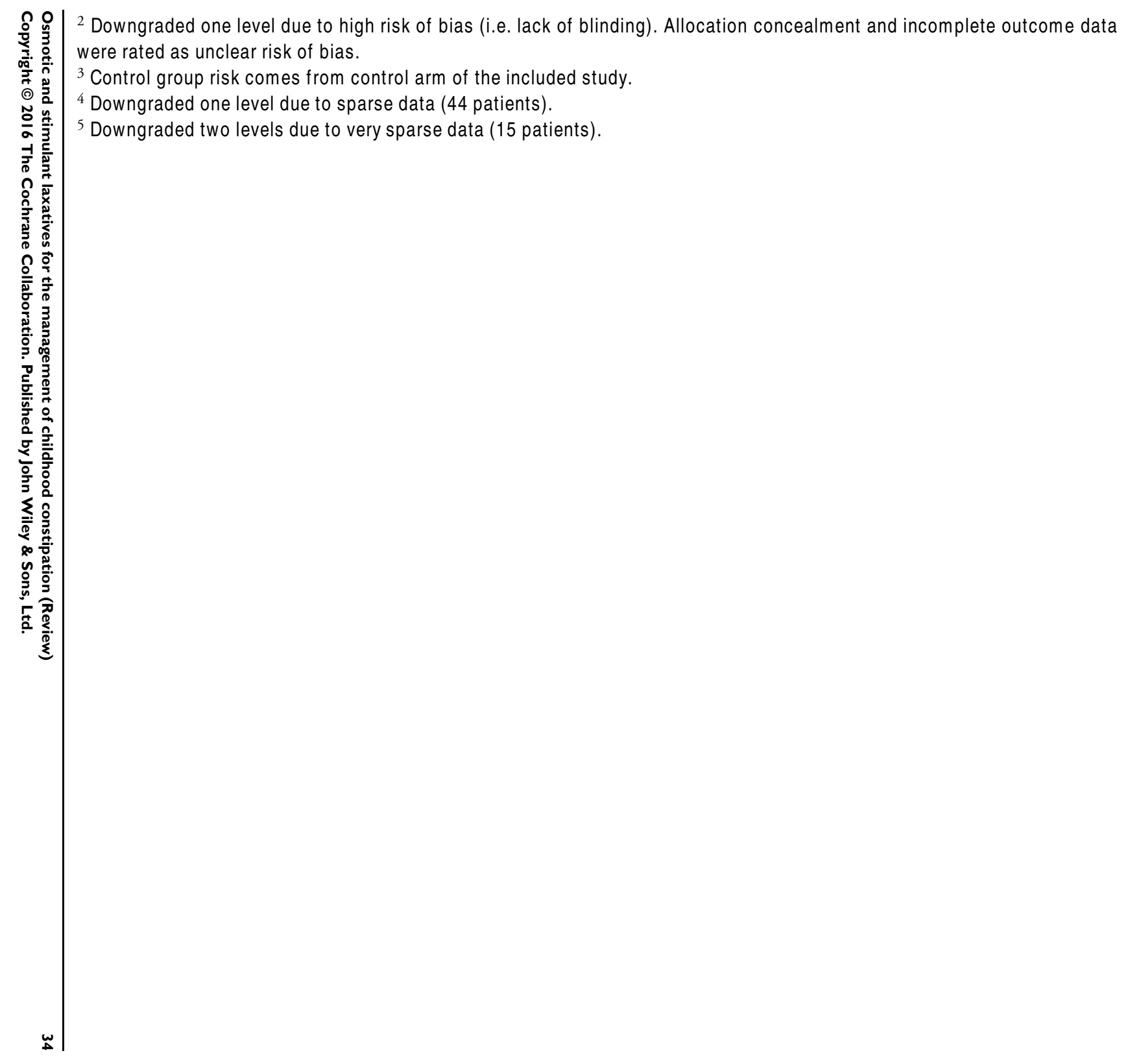


Lactulose versus partially hydrolyzed guar gum (PHGG) for the management of childhood constipation

Patient or population: patients aged 0 to 18 years with a diagnosis of functional constipation

Settings: outpatient

Intervention: Lactulose versus partially hydrolyzed guar gum (PHGG)

\begin{tabular}{|c|c|c|c|c|c|}
\hline \multirow[t]{3}{*}{ Outcomes } & \multicolumn{2}{|c|}{ Illustrative comparative risks* $(95 \% \mathrm{Cl})$} & \multirow{3}{*}{$\begin{array}{l}\text { Relative effect } \\
(95 \% \mathrm{Cl})\end{array}$} & \multirow{3}{*}{$\begin{array}{l}\text { No of Participants } \\
\text { (studies) }\end{array}$} & \multirow{3}{*}{$\begin{array}{l}\text { Quality of the evidence Comments } \\
\text { (GRADE) }\end{array}$} \\
\hline & Assumed risk & Corresponding risk & & & \\
\hline & Control & Lactulose versus PHGG & & & \\
\hline $\begin{array}{l}\text { Frequency of defeca- } \\
\text { tion (mean number of } \\
\text { bowel movements per } \\
\text { week) }\end{array}$ & $\begin{array}{l}\text { The mean number of } \\
\text { bowel movements in } \\
\text { the PHGG group was } 5 \text {. } \\
0 \text { per week }\end{array}$ & $\begin{array}{l}\text { The mean number of } \\
\text { bowel movements in } \\
\text { the lactulose group was } \\
\text { on average } 1.0 \text { higher } \\
\text { per week ( } 95 \% \mathrm{Cl}-1.80 \\
\text { to } 3.80 \text { ) }\end{array}$ & & $\begin{array}{l}61 \\
\text { (1 study) }\end{array}$ & $\begin{array}{l}\oplus \oplus \bigcirc \bigcirc \\
\text { low }^{1,2}\end{array}$ \\
\hline
\end{tabular}

* The basis for the assumed risk (e.g. the median control group risk across studies) is provided in footnotes. The corresponding risk (and its $95 \%$ confidence interval) is based on the assumed risk in the comparison group and the relative effect of the intervention (and its $95 \% \mathrm{Cl}$ ).

Cl: Confidence interval;

GRADE Working Group grades of evidence

High quality: Further research is very unlikely to change our confidence in the estimate of effect.

Moderate quality: Further research is likely to have an important impact on our confidence in the estimate of effect and may change the estimate.

Low quality: Further research is very likely to have an important impact on our confidence in the estimate of effect and is likely to change the estimate.

Very low quality: We are very uncertain about the estimate.

${ }^{1}$ Downgraded one level due to sparse data (61 patients).

2 Downgraded one level due to unclear risk of bias (i.e. random sequence generation, allocation concealment, blinding and selective reporting were rated as unclear risk of bias). 


\section{DISCUSSION}

\section{Summary of main results}

Lactulose was compared to liquid paraffin (Urganci 2005; Farahmand 2007), lactitol (Pitzalis 1995), milk of magnesia (Saneian 2012), dietary fibre (Kokke 2008), and partially hydrolyzed guar gum (Ustundag 2010) and senna (Perkin 1977). Despite the many agents that it was compared to, no trial found superiority of lactulose in terms of efficacy. Lactulose was found to be inferior to liquid paraffin and milk of magnesia. There were no studies comparing lactulose to placebo. In addition, the occurrence of minor adverse events, such abdominal cramps and flatus, were more common in the lactulose groups.

PEG was frequently studied, with trials comparing its efficacy for constipation with lactulose (Gremse 2002; Voskujl 2004; Dupont 2005; Candy 2006; Wang 2007; Saneian 2012; Treepongkaruna 2014), milk of magnesia (Loening-Baucke 2006; Ratanamongkol 2009; Gomes 2011; Saneian 2012), enema (Bekkali 2009), liquid paraffin (Tolia 1993; Karami 2009; Rafati 2011), flixweed (Nimrouzi 2015), dietary fibre (Quitadamo 2012) and placebo (Thomson 2007; Nurko 2008). Dziechciarz 2015 compared high dose PEG $(0.7 \mathrm{~g} / \mathrm{kg})$ to low dose PEG $(0.3 \mathrm{~g} / \mathrm{kg})$. PEG was found to be superior to placebo, lactulose, and milk of magnesia. However, the effect size was modest in these analyses, particularly for the pooled analysis of PEG versus milk of magnesia and PEG versus lactulose. Although PEG was superior to milk of magnesia and lactulose the magnitude of this difference was quite small and may not be clinically significant. One study $(\mathrm{N}=90)$ found high dose PEG $(0.7 \mathrm{~g} / \mathrm{kg})$ to be superior to low dose PEG $(0.3 \mathrm{~g} / \mathrm{kg})$ (Dziechciarz 2015). With the exception of one case of allergy to PEG, no significant adverse events were associated with the use of PEG and the limited evidence reported suggests that minor adverse events occur with a similar or reduced frequency.

A pooled analysis of two studies ( $\mathrm{n}=261$ participants) found no difference in efficacy between PEG and liquid paraffin. One study $(\mathrm{n}=80)$ found no difference between PEG and rectal enemas in efficacy for treating faecal impaction. Nimrouzi 2015 found no difference in efficacy between PEG and flixweed and Quitadamo 2012 found no difference between PEG and dietary fibre. However, no firm conclusions regarding efficacy can be drawn from these studies. None of these studies were designed to be formal equivalence of non-inferiority studies.

The largest treatment effect in terms of the frequency of defecation (i.e. number of stools per week), was seen with liquid paraffin (mineral oil) when compared to lactulose. While a number of case reports have been made that raise safety concerns about liquid paraffin in terms of the risk of aspiration pneumonia (Zanetti 2007), no cases of liquid paraffin-related pneumonia were reported in the trials in this review.

\section{Overall completeness and applicability of evidence}

While there are a large number of studies included in this review, it is clear that these studies are extremely heterogenous, with nine different study agents and a variety of specific treatment regimens reported. As such, despite the common nature of the problem, it is difficult to draw particularly strong conclusions for any of the investigated agents. The scope of this study was osmotic and stimulant laxatives, but the vast majority of studies investigated osmotic laxatives.

If we consider PEG, while this was the most studied agent in 19 different trials, with a total of 1757 participants, these studies compared PEG to seven different agents, as well as its use for constipation or faecal impaction. However, there was wide variation in study length and the time at which outcomes were assessed. Clearly, given the modest effect sizes and small sample sizes, coupled with these variations in treatment protocols (i.e. time of outcome assessment, use of additional therapies, specific form of interventional laxative used), the ability to use these findings to inform clinical practice is modest at best. These factors have certainly contributed to the statistical evidence of heterogeneity in intervention effects observed in meta-analyses comparing PEG to placebo or lactulose.

As constipation is a chronic problem, outcomes really need to be assessed in the medium to long term. However, only one study assessed outcomes beyond three months and half of the studies measured outcomes at one month or less. If management of chronic constipation is considered in terms of induction (disimpaction) and maintenance of remission, the limitation in the application of these results becomes apparent. It is difficult to comment on the ability of PEG or lactulose to maintain a child's normal bowel habits over the long term, when the studies have such short followup periods. In addition, outcomes such as frequency of defecation are inherently limited in relation to the realities of clinical practice. While there may be a statistically significant increase in rates of defecation between study groups, this does not give any information as to whether the patient or their parents feel that there has been a functional improvement.

\section{Quality of the evidence}

There were no studies that were judged to be fully free of risk of bias. While the majority of studies described themselves as randomised, only 10 studies provided enough detail to be judged as low risk of bias. The other studies were rated as unclear for random sequence generation. This was also the case for allocation concealment, again with the majority of studies giving insufficient detail to be judged as low risk of bias. Ten studies were open label (high risk of bias) or reported insufficient information to be judged as low risk of bias for blinding. Three studies were judged to be at high risk of bias for incomplete outcome data and five studies were 
judged to be at high risk of bias due to selective reporting. This has to be considered when judging the conclusions of this review. Furthermore, GRADE analyses indicated that the overall quality of the evidence for the primary outcome (number of stools per week) was low or very low due to sparse data, inconsistency (heterogeneity), and high risk of bias in the studies in the pooled analyses. Thus, given these concerns the results of the pooled analyses should be interpreted with caution.

\section{A U THORS'CONCLUSIONS}

\section{Implications for practice}

The evidence base suggests that PEG is moderately effective at improving the frequency of defecation in children with chronic constipation when compared to placebo and more effective than other agents, such as lactulose, milk of magnesia or liquid paraffin (mineral oil). It also appears to have a good safety profile, with minor adverse events common, but less so than with these other agents. Evidence from one study suggests that high dose PEG (0.7 $\mathrm{g} / \mathrm{kg})$ may be more effective than low dose PEG $(0.3 \mathrm{~g} / \mathrm{kg})$. The strength of the evidence base is limited by sparse data, inconsistency (clinical and statistical heterogeneity) and a high risk of bias in some studies included in the pooled analyses. It is also difficult to comment on the use of PEG for the long term management of childhood constipation as most studies only measured short term outcomes. While only two studies investigated liquid paraffin in comparison with lactulose, they found a reasonable effect size supporting the use of liquid paraffin. There was no evidence found to suggest lactulose is more effective than the other agents studied, but there was a lack of placebo controlled trials.

\section{Implications for research}

The evidence base for this extremely prevalent problem is small and published papers are generally of sub-optimal quality, as well as having problems with methodological, statistical and clinical heterogeneity. As such, the strength of our conclusions is extremely limited and more research is needed. Key questions that need addressing include the safety of liquid paraffin, given its apparent effectiveness, but limited investigation. In particular, future research should compare liquid paraffin to PEG. The optimal dose of PEG warrants further investigation. The role of PEG for the long term management of chronic constipation also needs further investigation to allow research to better inform actual clinical practice. There is a lack of studies comparing lactulose with placebo.

Future research should be clear at the outset as to whether it seeks to investigate the use of agents for the induction of remission from severe constipation, or whether it will investigate maintenance of normal bowel habits. Studies should be reported in sufficient detail to allow the methodology to be assessed and replicated by other researchers.

\section{ACKNOWLEDGEMENTS}

Partial funding for the Cochrane IBD Group (April 1, 2016 March 31, 2018) has been provided by Crohn's and Colitis Canada (CCC).

\section{REF E R E N C E S}

\section{References to studies included in this review}

Bekkali 2009 \{published data only\}

Bekkali NL, Dijkgraaf MG, Van Den Berg MM, Van Wijk MP, Bongers ME, Liem O, et al. Treatment of rectal fecal impaction a randomized controlled trial: Rectal enemas versus high doses of oral PEG 3350. Gastroenterology 2009; 136(5 Suppl 1):A128-9.

* Bekkali NL, van den Berg MM, Dijkgraaf MG, van Wijk MP, Bongers ME, Liem O, et al. Rectal fecal impaction treatment in childhood constipation: enemas versus high doses oral PEG. Pediatrics 2009;124(6):e1108-15.

Candy 2006 \{published data only\} Candy DC, Edwards D, Geraint M. Treatment of faecal impaction with polyethylene glycol plus electrolytes (PGE + E) followed by a double-blind comparison of PEG + E versus lactulose as maintenance therapy. Journal of Pediatric Gastroenterology and Nutrition 2006;43(1):65-70.
Dupont 2005 \{published data only\}

Dupont C, Leluyer B, Maamri N, Morali A, Joye J, Fiorini $\mathrm{J}$, et al. Double-blind randomized evaluation of clinical and biological tolerance of polyethylene glycol 4000 versus lactulose in constipated children. Journal of Pediatric Gastroenterology and Nutrition 2005;41(5):625-33.

Dziechciarz 2015 \{published data only\} Dziechciarz P, Horvath A, Szajewska H. Polyethylene glycol 4000 for treatment of functional constipation in children. Journal of Pediatric Gastroenterology and Nutrition 2015;60 (1):65-8.

Farahmand 2007 \{published data only\} Farahmand F. A randomised trial of liquid paraffin versus lactulose in the treatment of chronic functional constipation in children. Acta Medica Iranica 2007;45:183-8.

Gomes 2011 \{published data only\} Gomes PB, Duarte MA, Melo Mdo C. Comparison of the effectiveness of polyethylene glycol 4000 without electrolytes and magnesium hydroxide in the treatment 
of chronic functional constipation in children. Jornal de Pediatria 2011;87(1):24-8.

Gremse 2002 \{published data only\}

Gremse DA, Hixon J, Crutchfield A. Comparison of polyethylene glycol 3350 and lactulose for treatment of chronic constipation in children. Clinical Pediatrics 2002; 41(4):225-9.

Karami 2009 \{published data only\}

Karami H, Khademloo M, Niari P. Polyethylene glycol versus paraffin for the treatment of childhood functional constipation. Iranian Journal of Pediatrics 2009;19(3):25561.

Kokke 2008 \{published data only\}

Kokke FT, Scholtens PA, Alles MS, Decates TS, Fiselier TJ, Tolboom JJ, et al. A dietary fiber mixture versus lactulose in the treatment of childhood constipation: a doubleblind randomized controlled trial. Journal of Pediatric Gastroenterology and Nutrition 2008;47(5):592-7.

Loening-Baucke 2006 \{published data only\} Loening-Baucke V, Pashankar D. A randomized, prospective, comparison study of polyethylene glycol 3350 without electrolytes and milk of magnesia for children with constipation and fecal incontinence. Pediatrics 2006;118 (2):528-35.

Nimrouzi 2015 \{published data only\}

Nimrouzi M, Sadeghpour O, Imanieh MH, Shams Ardekani M, Salehi A, Minaei MB, et al. Flixweed vs. polyethylene glycol in the treatment of childhood functional constipation: A randomized clinical trial. Iranian Journal of Pediatrics 2015;25(2):e425.

Nurko 2008 \{published and unpublished data\}

Nurko S, Youssef NN, Sabri M, Langseder A, McGowan J, Cleveland M, et al. PEG3350 in the treatment of childhood constipation: a multicenter, double-blinded, placebocontrolled trial. Journal of Pediatrics 2008;153(2):254-61.

Perkin 1977 \{published data only\} Perkin JM. Constipation in childhood: a controlled comparison between lactulose and standardized senna. Current Medical Research and Opinion 1977;4(8):540-3.

Pitzalis 1995 \{published data only\} Pitzalis G, Deganello F, Mariani P, Chiarini-Testa MB, Virgilii F, Gasparri R, Calvani L, Bonamico M. Lactitol in chronic idiopathic constipation in children. Pediatria Medica e Chirurgica 1995;17(3):223-6.

Quitadamo 2012 \{published data only\} Quitadamo P, Coccorullo P, Del Giudice E, Mallardo S, Ferra V, Poli E, et al. Prospective, randomized, controlled, multicenter study on the effectiveness of polyethylene glycol 3350 with electrolytes versus a mixture of acacia fiber, psyllium fiber and fructose in the treatment of chronic functional constipation in childhood. Digestive and Liver Disease 2010;42:S355.

* Quitadamo P, Coccorullo P, Giannetti E, Romano C, Chiaro A, Campanozzi A, et al. A randomized, prospective, comparison study of a mixture of acacia fiber, psyllium fiber, and fructose vs polyethylene glycol 3350 with electrolytes for the treatment of chronic functional constipation in childhood. Journal of Pediatrics 2012;161(4):710-5.

\section{Rafati 2011 \{published data only\}}

Rafati MR, Karami H, Salehifar E, Karimzadeh A. Clinical efficacy and safety of polyethylene glycol 3350 versus liquid paraffin in the treatment of pediatric functional constipation. DARU 2011;19(2):154-8.

Ratanamongkol 2009 \{published data only\}

Ratanamongkola P, Lertmaharitb S, Jongpiputvanichc S. Polyethylene glycol 4000 without electrolytes versus milk of magnesia for the treatment of functional constipation in infants and young children: A randomized controlled trial. Asian Biomedicine 2009;3(4):391-9.

Saneian 2012 \{published data only\}

Saneian H, Mostofizadeh N. Comparing the efficacy of polyethylene glycol (PEG), magnesium hydroxide and lactulosein treatment of functional constipation in children. Journal of Research in Medical Sciences 2012;17(1 Suppl 1): S145-9.

Thomson 2007 \{published and unpublished data\} Thomson MA, Jenkins HR, Bisset WM, Heuschkel R, Kalra DS, Green MR, et al. Polyethylene glycol 3350 plus electrolytes for chronic constipation in children: a double blind, placebo controlled, crossover study. Archives of Disease in Childhood 2007;92(11):996-1000.

Tolia 1993 \{published data only\}

Tolia V, Lin CH, Elitsur Y. A prospective randomized study with mineral oil and oral lavage solution for treatment of faecal impaction in children. Alimentary Pharmacology and Therapeutics 1993;7(5):523-9.

\section{Treepongkaruna 2014 \{published data only\}} Treepongkaruna S, Simakachorn N, Pienvichit P, Magis A, Garnier P, Maisonobe P, et al. Efficacy of a polyethylene glycol laxative (PEG, Macrogol 4000) versus lactulose for the treatment of chronic constipation in children. Results of a randomized, double-blind controlled study performed in Thailand. Gastroenterology 2013;144(5 Suppl 1):S547.

* Treepongkaruna S, Simakachorn N, Pienvichit P, Varavithya W, Tongpenyai Y, Garnier P, et al. A randomised, double-blind study of polyethylene glycol 4000 and lactulose in the treatment of constipation in children. $B M C$ Pediatrics 2014;14:153.

\section{Urganci 2005 \{published data only\}}

Urganci N, Akyildiz B, Polat TB. A comparative study: the efficacy of liquid paraffin and lactulose in management of chronic functional constipation. Pediatrics International 2005;47(1):15-9.

\section{Ustundag 2010 \{published data only\}} * Ustundag G, Kuloglu Z, Kirbas N, Kansu A. Can partially hydrolyzed guar gum be an alternative to lactulose in treatment of childhood constipation?. Turkish Journal of Gastroenterology 2010;21(4):360-4.

Ustundag GH, Kuloglu Z, Kyrbas N, Kansu A. Can partially hydrolyzed guar gum be an alternative to lactulose 
in treatment of childhood constipation?. Journal of Pediatric Gastroenterology and Nutrition 2010;50:E120.

Voskujl 2004 \{published data only\}

Voskuijl W, de Lorijn F, Verwijs W, Hogeman P, Heijmans J, Mäkel W, et al. PEG 3350 (Transipeg) versus lactulose in the treatment of childhood functional constipation: a double blind, randomised, controlled, multicentre trial. Gut 2004;53(11):1590-4.

Wang 2007 \{published data only\}

* Wang BX, Wang MG, Jiang MZ, Xu CD, Shao CH, Jia LY, et al. Forlax in the treatment of childhood constipation: a randomized, controlled, multicenter clinical study. Zhongguo Dang Dai Er Ke Za Zhi 2007;9(5):429-32. Wang Y, Wang B, Jiang X, Jiang M, Xu C, Shao C, et al. Polyethylene glycol 4000 treatment for children with constipation: A randomized comparative multicenter study. Experimental and Therapeutic Medicine 2012;3(5):853-6.

\section{References to studies excluded from this review}

\section{Bekkali 2011 \{published data only\}}

Bekkali N, Liem O, Bongers ME, Van Wijk MP, Zegers B, Pelleboer R, et al. One year treatment of childhood constipation comparing PEG 3350 with electrolytes versus PEG 4000: A double blind randomized controlled trial. Journal of Pediatric Gastroenterology and Nutrition 2011;53: S78.

Bekkali NL, Liem O, Bongers ME, Van Wijk MP, Pelleboer $\mathrm{R}$, Koot B, et al. One year treatment of childhood constipation comparing PEG 3350 with electrolytes versus PEG 4000: A double blind randomized controlled trial. Gastroenterology 2012;142(5 Suppl 1):S821-2.

Berg 1983 \{published data only\}

Berg I, Forsythe I, Holt P, Watts J. A controlled trial of 'Senokot' in faecal soiling treated by behavioural methods. Journal of Child Psychology and Psychiatry and Allied Disciplines 1983;24(4):543-9.

Bongers 2009 \{published data only\}

Bongers ME, van den Berg MM, Reitsma JB, Voskuijl WP, Benninga MA. A randomized controlled trial of enemas in combination with oral laxative therapy for children with chronic constipation. Clinical Gastroenterology and Hepatology 2009;7(10):1069-74.

Connolly 1974 \{published data only\} Connolly P, Hughes IW, Ryan G. Comparison of "Duphalac" and "irritant" laxatives during and after treatment of chronic constipation: a preliminary study. Current Medical Research and Opinion 1974;2(10):620-5.

Corazziari 1996 \{published data only\}

Corazziari E, Badiali D, Habib FI, Reboa G, Pitto G, Mazzacca G, et al. Small volume isosmotic polyethylene glycol electrolyte balanced solution (PMF-100) in treatment of chronic nonorganic constipation. Digestive Diseases and Sciences 1996;41(8):1636-40.
Dehghani 2014 \{published data only\}

Dehghani SM, Askarian M, Kaffashan HA. Oral domperidone has no additional effect on chronic functional constipation in children: a randomized clinical trial. Indian Journal of Gastroenterology 2014;33(2):125-30.

Dupont 2006 \{published data only\}

Dupont C, Leluyer B, Amar F, Kalach N, Benhamou $\mathrm{PH}$, Mouterde $\mathrm{O}$, et al. A dose determination study of polyethylene glycol 4000 in constipated children: factors influencing the maintenance dose. Journal of Pediatric Gastroenterology and Nutrition 2006;42(2):178-85.

Ferguson 1999 \{published data only\}

Ferguson A, Culbert P, Gillett H, Barras N. New polyethylene glycol electrolyte solution for the treatment of constipation and faecal impaction. Italian Journal of Gastroenterology and Hepatology 1999;31 Supp 3:S249-52.

Hardikar 2007 \{published data only\}

Hardikar W, Cranswick N, Heine RG. Macrogol 3350 plus electrolytes for chronic constipation in children: a singlecentre, open-label study. Journal of Paediatrics and Child Health 2007;43(7-8):527-31.

Hejl 1990 \{published data only\}

Hejl M, Kamper J, Ebbesen F, Hansted C. Infantile constipation and Allomin-lactulose. Treatment of infantile obstipation in infants fed with breast milk substitutes. A controlled clinical trial of 2 per cent and 4 per cent Allominlactulose. Ugeskrift for Laeger 1990;152(25):1819-22.

Kazak 1999 \{published data only\}

Kazak SS, Beketova HV, Voronina SS, Amanbaieva HT. Forlax in the treatment of the constipation syndrome in children with combined digestive organ pathology. Likarska Sprava 1999, (7-8):142-7.

\section{Khoshoo 2006 \{published data only\}}

Khoshoo V, Armstead C, Landry L. Effect of a laxative with and without tegaserod in adolescents with constipation predominant irritable bowel syndrome. Alimentary Pharmacology and Therapeutics 2006;23(1):191-6.

Miller 2012 \{published data only\} Miller MK, Dowd MD, Friesen CA, Walsh-Kelly CM. A randomized trial of enema versus polyethylene glycol 3350 for fecal disimpaction in children presenting to an emergency department. Pediatric Emergency Care 2012;28 (2):115-9.

Ormarsson 2013 \{published data only\} Ormarsson OT, Asgrimsdottir GM, Stefansson E, Loftsson T, Bjornsson E. Marine lipid suppositories for constipation in children. Gastroenterology 2013;144(5 Suppl 1):S398-9.

Savino 2012 \{published data only\} Savino F, Viola S, Erasmo M, Di Nardo G, Oliva S, Cucchiara S. Efficacy and tolerability of peg-only laxative on faecal impaction and chronic constipation in children. A controlled double blind randomized study vs a standard peg-electrolyte laxative. BMC Pediatrics 2012;12:178. 
Shevtsov 2005 \{published data only\}

Shevtsov SA. Clinical efficacy of duphalac in the treatment

of functional constipations. E ksperimental'nai a $i$

Klinicheskai a Gastroè nterologii a 2005, (6):58-60.

Sonheimer 1982 \{published data only\}

Sondheimer JM, Gervaise EP. Lubricant versus laxative in the treatment of chronic functional constipation of children: a comparative study. Journal of Pediatric Gastroenterology and Nutrition 1982;1(2):223-6.

Youssef 2002 \{published data only\}

Youssef NN, Peters JM, Henderson W, Shultz-Peters S, Lockhart DK, Di Lorenzo C. Dose response of PEG 3350 for the treatment of childhood fecal impaction. Journal of Pediatrics 2002;141(3):410-4.

\section{Additional references}

\section{Anonymous 2006}

Anonymous. Evaluation and treatment of constipation in children: summary of updated recommendations of the North American Society for Pediatric Gastroenterology, Hepatology and Nutrition. Journal of Pediatric Gastroenterology and Nutrition 2006;43(3):405-7.

\section{Anonymous 2010}

Anonymous. Constipation in children and young people: diagnosis and management of idiopathic childhood constipation in primary and secondary care. Available from http://www.nice.org.uk/nicemedia/live/12993/48721/ 48721.pdf [Accessed 13th July 2010]. Published by the RCOG Press at the Royal College of Obstetricians and Gynaecologists, London, UK, 2010.

Baker 1999

Baker SS, Liptak GS, Colletti RB, Croffie JM, Di Lorenzo $\mathrm{C}$, Ector W, et al. Constipation in infants and children: evaluation and treatment. A medical position statement of the North American Society for Pediatric Gastroenterology and Nutrition. Journal of Pediatric Gastroenterology and Nutrition 1999;29(5):612-26.

\section{Guyatt 2008}

Guyatt GH, Oxman AD, Vist GE, Kunz R, Falck-Ytter Y, Alonso-Coello P, et al. GRADE: an emerging consensus on rating quality of evidence and strength of recommendations. BMJ 2008;336(7650):924-6.

\section{Higgins 2003}

Higgins JP, Thompson SG, Deeks JJ, Altman DG Measuring inconsistency in meta-analyses. BMJ 2003;327 (7414):557-560.

Higgins 2011a

Hggins JPT, Altman DG, Sterne JAC (editors). Chapter 8: Assessing risk of bias in included studies. In: Higgins JPT, Green S editor(s). Cochrane Handbook for Systematic Reviews of Interventions Version 5.1.0 (updated March 2011). The Cochrane Collaboration, 2011. Available from www.cochrane-handbook.org.
Higgins 2011b

Higgins JPT, Deeks JJ (editors). Chapter 7: Selecting studies and collecting data. In: Higgins JPT, Green S editor(s). Cochrane Handbook for Systematic Reviews of Interventions Version 5.1.0 (updated March 2011). The Cochrane Collaboration, 2011. Available from www.cochrane-handbook.org.

Hozo 2005

Hozo SP, Djulbegovic B, Hozo I. Estimating the mean and variance from the median, range, and the size of a sample. BMC Medical Research Methodology 2005;5:13.

\section{Hyman 2006}

Hyman PE, Milla PJ, Marc A. Childhood functional gastrointestinal disorders: neonate/toddler. Gastroenterology 2006;130(5):1519-26.

\section{Lee-Robichaud 2010}

Lee-Robichaud H, Thomas K, Morgan J, Nelson RL. Lactulose versus polyethylene glycol for chronic constipation. Cochrane Database of Systematic Reviews 2010, Issue 7. [DOI: 10.1002/14651858.CD007570.pub2]

Partin 1992

Partin JC, Hamill SK, Fischel JE, Partin JS. Painful defecation and fecal soiling in children. Pediatrics 1992;89 (6 Pt 1):1007-9.

Pijpers 2008

Pijpers MA, Tabbers MM, Benninga MA, Berger MY. Currently recommended treatments of childhood constipation are not evidence based: a systematic literature review on the effect of laxative treatment and dietary measures. Archives of Disease in Childhood 2009;94(2): $117-31$.

Pitkin 1999

Pitkin RM, Branagan MA, Burmeister LF. Accuracy of data in abstracts of published research articles. JAMA 1999;281 (12):1110-1.

\section{Price 2001}

Price KJ, Elliot TM. Stimulant laxatives for constipation and soiling in children. Cochrane Database of Systematic Reviews 2001, Issue 3. [DOI: 10.1002/14651858.CD002040]

Rasquin 2006

Rasquin A, Di Lorenzo C, Forbes D, Guiraldes E, Hyams J, Staiano A, et al. Childhood functional gastrointestinal disorders: child/adolescent. Gastroenterology 2006;130(5): 1527-37.

\section{Rasquin-Weber 1999}

Rasquin-Weber A, Hyman PE, Cucchiara S, Fleisher DR, Hyams JS, Milla PJ, et al. Childhood functional gastrointestinal disorders. Gut 1999;45 (Suppl 2):1160-8.

\section{Schünemann 2011}

Schünemann HJ, Oxman AD, Vist GE, Higgins JPT, Deeks JJ, Glasziou P, et al. Chapter 12: Interpreting results and drawing conclusions. In: Higgins JPT, Green S editor(s). Cochrane Handbook for Systematic Reviews of Interventions Version 5.1.0 (updated March 2011). 
The Cochrane Collaboration, 2011. Available from www.cochrane-handbook.org.

\section{Van den Berg 2006}

Van den Berg MM, Benninga MA, Di Lorenzo C. Epidemiology of childhood constipation: a systematic review. American Journal of Gastroenterology 2006;101(10): 2401-9.

\section{Zanetti 2007}

Zanetti G, Marchiori E, Gasparetto TD, Escuissato DL, Soares Souza A Jr. Lipoid pneumonia in children following aspiration of mineral oil used in the treatment of constipation: high-resolution CT findings in 17 patients. Pediatric Radiology 2007;37(11):1135-9.

\section{References to other published versions of this review}

\section{Gordon 2012}

Gordon M, Naidoo K, Akobeng AK, Thomas AG. Osmotic and stimulant laxatives for the management of childhood constipation. Cochrane Database of Systematic Reviews 2012, Issue 7. [DOI: 10.1002/14651858.CD009118.pub2]

\section{Gordon 2013}

Gordon M, Naidoo K, Akobeng AK, Thomas AG.

Cochrane Review: Osmotic and stimulant laxatives for the management of childhood constipation (Review). EvidenceBased Child Health a Cochrane Review Journal 2013;8(1): 57-109.

* Indicates the major publication for the study 


\section{CHARACTERISTICS OF STUDIES}

\section{Characteristics of included studies [ordered by study ID]}

Bekkali 2009

\begin{tabular}{ll} 
Methods & $\begin{array}{l}\text { Randomised controlled open label trial PEG + electrolytes versus enemas for faecal } \\
\text { impaction }\end{array}$ \\
\hline Participants & $\begin{array}{l}90 \text { children between } 4 \text { and } 16 \text { years of age and demonstrated evidence of faecal impaction } \\
\text { on rectal examination } \\
\text { Participants had to fulfil }>1 \text { Rome III criteria for functional constipation present for } 8 \\
\text { weeks: } \\
\text { (1) defecation frequency of } 3 \text { times per week }\end{array}$ \\
$\begin{array}{l}\text { (2) }>1 \text { faecal incontinence episode per week } \\
\text { (3) history of retentive posturing or excessive volitional stool retention } \\
\text { (4) history of painful or hard defecation }\end{array}$ \\
$\begin{array}{l}\text { (5) history of large-diameter stools that may obstruct the toilet } \\
\text { Patients with a history of colorectal surgery or an organic cause for constipation were } \\
\text { excluded }\end{array}$ \\
$\begin{array}{l}\text { Peg } 3350+\text { electrolytes (Movicolon, Norgine, Amsterdam) } 1.5 \mathrm{~g} / \mathrm{kg} \text { per day for } 6 \text { con- } \\
\text { secutive days - then maintenance }(0.5 \mathrm{~g} / \mathrm{kg} \text { per day) for } 2 \text { weeks }\end{array}$ \\
$\begin{array}{l}\text { Dioctylsulfosuccinate sodium enemas (Klyx, Pharmachemie, Haarlem, The Nether- } \\
\text { lands) } \\
\text { Once daily for } 6 \text { consecutive days }(60 \mathrm{~mL} \text { for children }<6 \text { years of age and } 120 \mathrm{~mL} \text { for } \\
\text { children }>6 \text { years of age) }\end{array}$
\end{tabular}

Outcomes

The primary outcome was successful disimpaction. Secondary outcome measures of defecation and faecal incontinence frequency, abdominal pain, watery stools, CTT values, and child's behavior scores were calculated for children who completed the study protocol Follow-up for 2 weeks

Notes

Risk of bias

\begin{tabular}{l|l|l} 
Bias & Authors' judgement & Support for judgement \\
\hline $\begin{array}{l}\text { Random sequence generation (selection } \\
\text { bias) }\end{array}$ & Unclear risk & Not described \\
\hline $\begin{array}{l}\text { Allocation concealment (selection bias) } \\
\text { Blinding (performance bias and detection } \\
\text { bias) } \\
\text { All outcomes }\end{array}$ & Unclear risk risk & Not described \\
\hline $\begin{array}{l}\text { Incomplete outcome data (attrition bias) } \\
\text { All outcomes }\end{array}$ & Low risk & Open label \\
\hline
\end{tabular}

Osmotic and stimulant laxatives for the management of childhood constipation (Review) 
Bekkali 2009 (Continued)

\begin{tabular}{l|ll}
\hline Selective reporting (reporting bias) & High risk & No adverse event data reported \\
\hline Other bias & Low risk & None apparent \\
\hline
\end{tabular}

Candy 2006

Methods

Open label treatment of faecal impaction with PEG + electrolytes followed by a randomised double blind controlled trial of PEG + electrolytes versus lactulose

Only data from second phase of the trial were analysed

Children aged 2 to 11 years could be enrolled in the study if they had intractable
constipation that had failed to respond to conventional treatment and would require
hospital admission for disimpaction
58 children were enrolled
All patients included had successfully been disimpacted in phase 1 of the trial
Children were excluded if they had any condition contraindicating the use of PEG + E
or lactulose or pre-existing organic pathology

Interventions

PEG 3350 + electrolytes (Movicol, Norgine, UK) 1 sachet per day (mean) versus lactulose (10 g lactulose powder dissolved in at least $125 \mathrm{~mL}$ water), 2.5 sachets per day (mean) Concomitant use of senna allowed

Outcomes

The primary outcome was the mean number of defecations per week. Secondary outcomes included amount of stool, problems on defecation (pain, straining, abdominal pain, rectal bleeding or soiling). Follow-up for 12 weeks

Notes

Risk of bias

\begin{tabular}{|c|c|c|}
\hline Bias & Authors' judgement & Support for judgement \\
\hline $\begin{array}{l}\text { Random sequence generation (selection } \\
\text { bias) }\end{array}$ & Low risk & $\begin{array}{l}\text { Study sponsor contacted and confirmed } \\
\text { they generated a computerised randomisa- } \\
\text { tion list }\end{array}$ \\
\hline Allocation concealment (selection bias) & Unclear risk & Not described \\
\hline
\end{tabular}

Blinding (performance bias and detection Low risk bias)

Similar appearance of products, identical packaging

All outcomes

Incomplete outcome data (attrition bias) Low risk All outcomes
Of the 10 children (17\%) who did not complete phase 2 , seven withdrew whilst taking lactulose because re-impaction occurred, two (from the lactulose group) did not want to continue and one (from the PEG + E group) did not complete the diary 
Candy 2006 (Continued)

card

\begin{tabular}{lll}
\hline Selective reporting (reporting bias) & Low risk & Data reported appropriately \\
\hline Other bias & Low risk & None apparent \\
\hline
\end{tabular}

Dupont 2005

\begin{tabular}{ll}
\hline Methods & Randomised double blind controlled trial of PEG 4000 versus lactulose \\
\hline Participants & $\begin{array}{l}96 \text { children aged } 6 \text { months to } 3 \text { years with constipation despite the usual dietary treatment } \\
\text { for at least } 1 \text { month } \\
\text { Children were ineligible if they had a history of intractable fecaloma or organic gastroin- } \\
\text { testinal disease such as Hirschsprung disease }\end{array}$ \\
\hline
\end{tabular}

Interventions

PEG 40001 sachet (4 g/sachet) versus Lactulose 1 sachet $/(3.33$ grames/sachet $)$ - the dose could be doubled if ineffective

If the maximum authorized dose was unsuccessful, one micro-enema (glycerol) per day could be prescribed for a maximum of 3 consecutive days

If the child produced no stools after treatment two enemas could be administered at a 48-hour interval

Outcomes

The primary endpoint was biological tolerance

Secondary endpoints included clinical efficacy measured by stool frequency and consistency, disappearance of abdominal pain and bloating

Follow-up was up to 12 weeks

Notes

Risk of bias

Bias

Authors' judgement

Support for judgement

Random sequence generation (selection Unclear risk

Not described

bias)

\begin{tabular}{l|l|l}
\hline Allocation concealment (selection bias) & Unclear risk & Not described \\
\hline $\begin{array}{l}\text { Blinding (performance bias and detection } \\
\text { bias) } \\
\text { All outcomes }\end{array}$ & Low risk & Described and appropriate \\
\hline $\begin{array}{l}\text { Incomplete outcome data (attrition bias) } \\
\text { All outcomes }\end{array}$ & Low risk & Drop-outs were balanced across treatment \\
\hline gelective reporting (reporting bias) & Low risk & Datalar reported appropriately \\
\hline Other bias & Low risk & None apparent \\
\hline
\end{tabular}

Osmotic and stimulant laxatives for the management of childhood constipation (Review)

Copyright $\odot 2016$ The Cochrane Collaboration. Published by John Wiley \& Sons, Ltd. 
Methods

Participants
Randomised open-label trial comparing high dose to low dose PEG 4000

92 children 1 to 18 years of age with functional constipation defined according to the Rome III criteria

Children with a diagnosis of irritable bowel syndrome, mental retardation, endocrine disease, an organic cause of defecation disorders, functional non-retentive fecal incontinence, or intake of medications influencing gastrointestinal motility were excluded

PEG $40000.7 \mathrm{~g} / \mathrm{kg}$ (Forlax) for 6 weeks $(\mathrm{n}=45)$

PEG $40000.3 \mathrm{~g} / \mathrm{kg}$ for 6 weeks $(\mathrm{n}=47)$

Primary outcome: treatment success, defined as 3 or more bowel movements per week with no fecal soiling during the last week of the intervention

Secondary outcomes: need for therapy adjustment, the number of stools per week, painful defecation, abdominal pain, fecal incontinence, parental satisfaction treatment $(10-\mathrm{cm}$ visual analog scale during the final visit), adverse events and compliance

Assessment of outcome measures was based on the diaries collected during the final visit Compliance was assessed during telephone contacts every 2 weeks and at the final visit at week 6

Notes

\section{Risk of bias}

\begin{tabular}{|c|c|c|}
\hline Bias & Authors' judgement & Support for judgement \\
\hline $\begin{array}{l}\text { Random sequence generation (selection } \\
\text { bias) }\end{array}$ & Low risk & $\begin{array}{l}\text { Block randomisation, with a block size of } 4 \text {, } \\
\text { was done with a computer-generated ran- } \\
\text { dom number list prepared by an investiga- } \\
\text { tor with no clinical involvement in the trial }\end{array}$ \\
\hline Allocation concealment (selection bias) & Low risk & $\begin{array}{l}\text { Centralized randomisation conducted by } \\
\text { an by an investigator with no clinical in- } \\
\text { volvement in the trial } \\
\text { The list was concealed from the clinicians } \\
\text { enrolling patients and assessing outcomes, } \\
\text { as well as from the parents, until the end of } \\
\text { the study }\end{array}$ \\
\hline $\begin{array}{l}\text { Blinding (performance bias and detection } \\
\text { bias) } \\
\text { All outcomes }\end{array}$ & High risk & Open-label study \\
\hline
\end{tabular}

Incomplete outcome data (attrition bias) Low risk All outcomes

Selective reporting (reporting bias) Low risk
One child in the high-dose group and 1 child in the low-dose group discontinued the study and were lost to follow-up

Data reported appropriately 
Dziechciarz 2015 (Continued)

\begin{tabular}{|c|c|c|}
\hline Other bias & Low risk & None apparent \\
\hline
\end{tabular}

\section{Farahmand 2007}

\begin{tabular}{|c|c|c|}
\hline Methods & \multicolumn{2}{|c|}{ Randomised controlled open label trial comparing liquid paraffin versus lactulose } \\
\hline Participants & \multicolumn{2}{|c|}{$\begin{array}{l}247 \text { children aged } 1 \text { month to } 12 \text { years with diagnosis of functional constipation } \\
\text { Children with organic causes for defecation disorders were excluded from the study }\end{array}$} \\
\hline Interventions & \multicolumn{2}{|c|}{$\begin{array}{l}\text { Liquid paraffin or lactulose, } 1-2 \mathrm{ml} / \mathrm{kg} \text { twice daily for each drug, for } 8 \text { weeks, increase } \\
\text { or decrease of volume of each drug allowed by } 25 \% \text { every } 3 \text { days as required, to yield, } 1 \\
\text { or } 2 \text {, firm to loose stools } \\
\text { Patients received one or two enemas daily for two days to clear any rectal impaction at } \\
\text { study entry }\end{array}$} \\
\hline Outcomes & \multicolumn{2}{|c|}{$\begin{array}{l}\text { Primary outcome was the number of successful bowel movements per week, with treat- } \\
\text { ment success defined as three or more episodes per week } \\
\text { Secondary outcomes were the incidence and severity of adverse events } \\
\text { Follow-up was for } 8 \text { weeks }\end{array}$} \\
\hline \multicolumn{3}{|l|}{ Notes } \\
\hline \multicolumn{3}{|l|}{ Risk of bias } \\
\hline Bias & Authors' judgement & Support for judgement \\
\hline $\begin{array}{l}\text { Random sequence generation (selection } \\
\text { bias) }\end{array}$ & Unclear risk & Not described \\
\hline Allocation concealment (selection bias) & Unclear risk & Not described \\
\hline $\begin{array}{l}\text { Blinding (performance bias and detection } \\
\text { bias) } \\
\text { All outcomes }\end{array}$ & High risk & Open label \\
\hline $\begin{array}{l}\text { Incomplete outcome data (attrition bias) } \\
\text { All outcomes }\end{array}$ & Low risk & $\begin{array}{l}\text { Drop-outs were balanced across treatment } \\
\text { groups with similar reasons for withdrawal }\end{array}$ \\
\hline Selective reporting (reporting bias) & Low risk & Data reported appropriately \\
\hline Other bias & Low risk & None apparent \\
\hline
\end{tabular}


Methods

Participants
Randomised controlled open label trial comparing PEG to magnesium hydroxide

38 children aged 1 to 15 years old with functional constipation according to the Rome III criteria

Children with excluded organic causes, neurological problems or previous surgery to the digestive system were excluded

Interventions

$1 \mathrm{~mL} / \mathrm{kg} /$ day for magnesium hydroxide (maximum dose $3 \mathrm{~mL} / \mathrm{kg} /$ day, up to $60 \mathrm{~mL} /$ day) and $0.5 \mathrm{~g} / \mathrm{kg} /$ day for PEG (maximum dose $1.5 \mathrm{~g} / \mathrm{kg} /$ day, up to $48 \mathrm{~g} /$ day)
Outcomes included: Stool characteristics (Bristol), frequency of bowel movements (number of movements per week), abdominal pain, straining, faecal incontinence, and acceptance of medication

Therapeutic interventions were considered failures when there was lack of acceptance, vomiting upon administration or absence of improvement in frequency of bowel movements and/or ongoing Bristol types 1, 2 or with use of maximum doses of the medication from the moment of the first return appointment

Notes

Risk of bias

\begin{tabular}{|c|c|c|}
\hline Bias & Authors' judgement & Support for judgement \\
\hline $\begin{array}{l}\text { Random sequence generation (selection } \\
\text { bias) }\end{array}$ & Unclear risk & Not described \\
\hline Allocation concealment (selection bias) & Unclear risk & Not described \\
\hline $\begin{array}{l}\text { Blinding (performance bias and detection } \\
\text { bias) } \\
\text { All outcomes }\end{array}$ & High risk & Open label \\
\hline $\begin{array}{l}\text { Incomplete outcome data (attrition bias) } \\
\text { All outcomes }\end{array}$ & High risk & No details regarding dropouts reported \\
\hline Selective reporting (reporting bias) & High risk & $\begin{array}{l}\text { No details regarding adverse events re- } \\
\text { ported }\end{array}$ \\
\hline Other bias & Low risk & None apparent \\
\hline
\end{tabular}

Gremse 2002

Methods

Participants
Randomised controlled open label crossover trial of PEG versus lactulose

37 children aged 2 to 16 years of age who were referred for subspecialty evaluation of constipation completed the study

Children with organic disease were excluded 
Gremse 2002 (Continued)

\begin{tabular}{|c|c|c|}
\hline Interventions & \multicolumn{2}{|c|}{$\begin{array}{l}\text { PEG } 3350 \text { (Miralax, Braintree Laboratories, Inc, Braintree,MA) } 10 \mathrm{~g} / \mathrm{m}^{2} / \text { day or lactulose } \\
1.3 \mathrm{~g} / \mathrm{kg} / \text { day both for two weeks and then patients switched agents for a further two } \\
\text { weeks }\end{array}$} \\
\hline Outcomes & \multicolumn{2}{|c|}{$\begin{array}{l}\text { Primary outcome was number of defecations per week } \\
\text { Secondary outcomes included stool form, ease of passage and global assessments by } \\
\text { parents } \\
4 \text { week follow-up }\end{array}$} \\
\hline \multicolumn{3}{|l|}{ Notes } \\
\hline \multicolumn{3}{|l|}{ Risk of bias } \\
\hline Bias & Authors' judgement & Support for judgement \\
\hline $\begin{array}{l}\text { Random sequence generation (selection } \\
\text { bias) }\end{array}$ & Unclear risk & Not described \\
\hline Allocation concealment (selection bias) & Unclear risk & Not described \\
\hline $\begin{array}{l}\text { Blinding (performance bias and detection } \\
\text { bias) } \\
\text { All outcomes }\end{array}$ & High risk & Open label \\
\hline $\begin{array}{l}\text { Incomplete outcome data (attrition bias) } \\
\text { All outcomes }\end{array}$ & Low risk & $\begin{array}{l}\text { Seven patients withdrew during the first } 2 \text { - } \\
\text { week treatment period due to lack of effi- } \\
\text { cacy of the assigned stool softener. } \\
\text { Six of the patients were taking lactulose at } \\
\text { the time of withdrawal, while the other sub- } \\
\text { ject was taking PEG } 3350\end{array}$ \\
\hline Selective reporting (reporting bias) & High risk & $\begin{array}{l}\text { Details not reported - no response from au- } \\
\text { thor }\end{array}$ \\
\hline Other bias & Low risk & None apparent \\
\hline
\end{tabular}

Karami 2009

Methods

Participants

Interventions
Randomised, single-blind trial comparing PEG to liquid paraffin

126 functionally constipated children aged 1 to 15 years

Children with organic constipation, anorectal abnormalities, or a history of anorectal surgery were excluded

PEG $40 \%$ solution without electrolytes at an average dose of $1 \mathrm{cc} / \mathrm{kg}$ (equal to $0.8 \mathrm{~g} / \mathrm{kg}$ ) . twice a day for one month $(n=48)$

Liquid paraffin at an average dose of $1 \mathrm{cc} / \mathrm{kg}$ was given twice daily for one month $(\mathrm{n}=$ 55) 
Karami 2009 (Continued)

\begin{tabular}{|c|c|c|}
\hline Outcomes & \multicolumn{2}{|c|}{$\begin{array}{l}\text { Stool frequency per week, painful defecation, blood-stained stools, stool consistency and } \\
\text { number of encopresis occurrences per month } \\
\text { Therapeutic response (sum of above outcomes) was scored as follows: poor (6-10), mod- } \\
\text { erate (11-15) and good (16-21) } \\
\text { Patients were followed up every week for one month, thereafter monthly for } 2 \text { to } 4 \\
\text { months }\end{array}$} \\
\hline \multicolumn{3}{|l|}{ Notes } \\
\hline \multicolumn{3}{|l|}{ Risk of bias } \\
\hline Bias & Authors' judgement & Support for judgement \\
\hline $\begin{array}{l}\text { Random sequence generation (selection } \\
\text { bias) }\end{array}$ & Unclear risk & Not described \\
\hline Allocation concealment (selection bias) & Unclear risk & Not described \\
\hline $\begin{array}{l}\text { Blinding (performance bias and detection } \\
\text { bias) } \\
\text { All outcomes }\end{array}$ & High risk & Single-blind \\
\hline $\begin{array}{l}\text { Incomplete outcome data (attrition bias) } \\
\text { All outcomes }\end{array}$ & High risk & $\begin{array}{l}23 \text { children did not complete the study, } \\
\text { it is unclear to which group these chil- } \\
\text { dren were randomised and reasons for with- } \\
\text { drawal were not described }\end{array}$ \\
\hline Selective reporting (reporting bias) & Low risk & $\begin{array}{l}\text { Data appear to be reported appropriately } \\
\text { The authors report that there were no side } \\
\text { effects in the discussion section }\end{array}$ \\
\hline Other bias & Low risk & None apparent \\
\hline
\end{tabular}

Kokke 2008

Methods

Participants

Interventions
Randomised double blind controlled trial of a dietary fibre mix versus lactulose

135 children ages 1 to 13 years were included

Children with organic causes of defecation disorders were excluded

Patients received either a yogurt drink containing lactulose $(10 \mathrm{~g} / 125 \mathrm{~mL}$, Duphalac Lactulose, Solvay, the Netherlands).or a mixed dietary fibre $(10 \mathrm{~g} / 125 \mathrm{~mL})$

The fibre mixture yogurt contained $3.0 \mathrm{~g}$ transgalacto-oligosaccharides (Vivinal GOS Elixor Sirup, Friesland Foods Domo, Zwolle, the Netherlands), $3.0 \mathrm{~g}$ inulin (Frutafit TEX, Cosun, Roosendaal, the Netherlands), $1.6 \mathrm{~g}$ soy fibre (Fibrim 2000, J. Rettenmaier \& Sohne, Ellwangen, Germany), and 0.33 g resistant starch 3 (Novelose 330, National Starch\&Chemical GmbH, Neustadt, Germany) per $100 \mathrm{~mL}$ 
Kokke 2008 (Continued)

\begin{tabular}{|c|c|c|}
\hline Outcomes & \multicolumn{2}{|c|}{$\begin{array}{l}\text { The primary outcome parameter was defecation frequency per week } \\
\text { Secondary outcome parameters included faecal incontinence each day stool consistency } \\
\text { and flatulence } \\
\text { Follow-up was for } 12 \text { weeks }\end{array}$} \\
\hline \multicolumn{3}{|l|}{ Notes } \\
\hline \multicolumn{3}{|l|}{ Risk of bias } \\
\hline Bias & Authors' judgement & Support for judgement \\
\hline $\begin{array}{l}\text { Random sequence generation (selection } \\
\text { bias) }\end{array}$ & Low risk & Computer generated list \\
\hline Allocation concealment (selection bias) & Low risk & $\begin{array}{l}\text { Sequence allocation coordinated by exter- } \\
\text { nal research organisation }\end{array}$ \\
\hline $\begin{array}{l}\text { Blinding (performance bias and detection } \\
\text { bias) } \\
\text { All outcomes }\end{array}$ & Low risk & $\begin{array}{l}\text { Bottles with yogurt were prepared and } \\
\text { packed by Numico Research (Wageningen, } \\
\text { the Netherlands) } \\
\text { Storage and delivery were supervised by the } \\
\text { local hospital pharmacist } \\
\text { The treatment products could not be dis- } \\
\text { tinguished from each other with respect to } \\
\text { colour, taste, or consistency }\end{array}$ \\
\hline $\begin{array}{l}\text { Incomplete outcome data (attrition bias) } \\
\text { All outcomes }\end{array}$ & Low risk & $\begin{array}{l}22 \text { participants in the fibre group dropped } \\
\text { out compared to } 11 \text { participants in the lac- } \\
\text { tulose group }\end{array}$ \\
\hline Selective reporting (reporting bias) & Low risk & Data reported appropriately \\
\hline Other bias & Low risk & None apparent \\
\hline
\end{tabular}

\section{Loening-Baucke 2006}

\begin{tabular}{ll} 
Methods & $\begin{array}{l}\text { Randomised controlled open label trial comparing PEG } 3350 \text { without electrolytes with } \\
\text { milk of magnesia }\end{array}$ \\
\hline Participants & $\begin{array}{l}79 \text { children aged }>4 \text { years and presence of functional constipation with faecal inconti- } \\
\text { nence } \\
\text { Exclusion criteria included organic causes for symptoms, toileting refusal or medication } \\
\text { refusal }\end{array}$ \\
\hline Interventions & $\begin{array}{l}\text { PEG } 0.7 \mathrm{~g} / \mathrm{kg} \text { body weight daily or milk of magnesia } 2 \mathrm{~mL} / \mathrm{kg} \text { body weight daily } \\
\text { Instructions were given to parents on how to vary doses to achieve acceptable stools } \\
\text { Children were disimpacted with } 1 \text { or } 2 \text { phosphate enemas in the clinic on the day of the }\end{array}$
\end{tabular}


visit, if necessary, and started laxative therapy that evening

Senna was allowed

Outcomes

Primary outcome was Improvement defined as 3 bowel movements per week, 2 episodes of faecal incontinence per month, and no abdominal pain, with or without laxative therapy

Secondary outcomes included (1) improvement in stool frequency per week, improvement in episodes of faecal incontinence per week, and resolution of abdominal pain; (2) safety profile; and (3) patient's acceptance and compliance

Follow-up was for 12 months

Notes

Risk of bias

\begin{tabular}{l|ll}
\hline Bias & Authors' judgement & Support for judgement \\
\hline $\begin{array}{l}\text { Random sequence generation (selection } \\
\text { bias) }\end{array}$ & Low risk & Drawing lots \\
\hline $\begin{array}{l}\text { Allocation concealment (selection bias) } \\
\text { Blinding (performance bias and detection } \\
\text { bias) } \\
\text { All outcomes }\end{array}$ & Low risk risk & Assignments in sealed envelopes \\
\hline $\begin{array}{l}\text { Incomplete outcome data (attrition bias) } \\
\text { All outcomes }\end{array}$ & Low risk & Open label \\
\hline $\begin{array}{l}\text { Selective reporting (reporting bias) } \\
\text { Other bias }\end{array}$ & Low risk & $\begin{array}{l}\text { 19 patients dropped out of the milk of mag- } \\
\text { nesia group compared to 5 patients in the } \\
\text { PEG group }\end{array}$ \\
\hline
\end{tabular}

Nimrouzi 2015

\begin{tabular}{l|l} 
Methods & $\begin{array}{l}\text { Randomised open label trial comparing PEG to flixweed (Descurainia sophia L.) (D. } \\
\text { sophia) }\end{array}$ \\
\hline Participants & $\begin{array}{l}120 \text { children aged } 2-12 \text { years old who met the Rome III criteria were enrolled in the } \\
\text { study } \\
\text { Children with organic causes of constipation including Hirschsprung's disease, spina bi- } \\
\text { fida occulta, hypothyroidism, cystic fibrosis, neurologic abnormalities, intestinal pseudo- } \\
\text { obstruction, and diabetes mellitus were excluded }\end{array}$ \\
\hline Interventions & $\begin{array}{l}\text { PEG ( } 40 \% \text { solution without electrolytes) at a dose of } 0.4 \mathrm{~g} / \mathrm{kg} \text { for } 8 \text { weeks }(\mathrm{n}=53) \\
\text { Flixweed at a dose of } 2 \mathrm{~g} / \text { day for children } 2-4 \text { years old and } 3 \mathrm{~g} / \mathrm{day} \text { for children } 4-12 \\
\text { years old patients taken once daily for } 8 \text { weeks }(\mathrm{n}=56)\end{array}$
\end{tabular}




\section{Nimrouzi 2015 (Continued)}

\begin{tabular}{|c|c|c|}
\hline Outcomes & \multicolumn{2}{|c|}{$\begin{array}{l}\text { Primary outcome: proportion of patients who responded to treatment, defined as im- } \\
\text { provement of constipation (at least three bowel movements per week), soft stool and } \\
\text { convenient defecation, no soiling or bloody stool as well as exiting the Rome III criteria } \\
\text { for constipation after the third week } \\
\text { Secondary outcomes: stool frequency, abdominal pain, drug compliance, hard stool } \\
\text { frequency, painful defecation, retention, soiling, blood stained stool, adverse events, need } \\
\text { for additional therapy } \\
\text { The efficacy of the intervention in both groups was evaluated at three weeks and eight } \\
\text { weeks of follow-up }\end{array}$} \\
\hline Notes & \multicolumn{2}{|c|}{$\begin{array}{l}\text { Patients were withdrawn from the study if they had no bowel movement for seven days } \\
\text { or developed fecal impaction }\end{array}$} \\
\hline \multicolumn{3}{|l|}{ Risk of bias } \\
\hline Bias & Authors' judgement & Support for judgement \\
\hline $\begin{array}{l}\text { Random sequence generation (selection } \\
\text { bias) }\end{array}$ & Unclear risk & $\begin{array}{l}\text { Block randomisation: method not de- } \\
\text { scribed }\end{array}$ \\
\hline Allocation concealment (selection bias) & Unclear risk & Not described \\
\hline $\begin{array}{l}\text { Blinding (performance bias and detection } \\
\text { bias) } \\
\text { All outcomes }\end{array}$ & High risk & Open label \\
\hline $\begin{array}{l}\text { Incomplete outcome data (attrition bias) } \\
\text { All outcomes }\end{array}$ & Unclear risk & $\begin{array}{l}11 \text { patients withdrew consent during the } \\
\text { first week of treatment, the authors do not } \\
\text { report to which group these patients were } \\
\text { randomised }\end{array}$ \\
\hline Selective reporting (reporting bias) & Low risk & Data reported appropriately \\
\hline Other bias & Low risk & None apparent \\
\hline
\end{tabular}

Nurko 2008

\begin{tabular}{ll} 
Methods & Randomised, multicenter, double-blind trial comparing PEG 3350 with placebo \\
\hline Participants & $\begin{array}{l}103 \text { children } 4 \text { to } 16 \text { years of age } \\
\text { Patients who were taking other laxatives were included only if they had }>3 \text { bowel } \\
\text { movements per week while taking the laxative, and all laxatives were stopped at least } 2 \\
\text { days before the run-in period started } \\
\text { Exclusion criteria included children with organic causes of constipation }\end{array}$ \\
\hline Interventions & $\begin{array}{l}\text { PEG3350, (MiraLax, Braintree Laboratories, Inc; Braintree, MA) at doses of } 0.2,0.4, \\
0.6 \text { or } 0.8 \text { grams per kilogram per day or placebo. (Crystallight, Proctor and Gamble; } \\
\text { Cincinnati, OH) }\end{array}$
\end{tabular}


Nurko 2008 (Continued)

All participants received behavioural modification

Outcomes

The primary outcome was the proportion of patients who responded to treatment response to treatment was defined as $>3$ bowel movements during the second week of treatment

Secondary efficacy variables included the weekly number of BM and faecal incontinence episodes and changes in the scores of stool consistency, straining, and abdominal cramping

2 weeks follow-up

Notes

Additional Mean and Standard deviation data regarding the frequency of defecations were obtained from Braintree Labs Inc

Risk of bias

\begin{tabular}{|c|c|c|}
\hline Bias & Authors' judgement & Support for judgement \\
\hline $\begin{array}{l}\text { Random sequence generation (selection } \\
\text { bias) }\end{array}$ & Unclear risk & Not described \\
\hline Allocation concealment (selection bias) & Unclear risk & Not described \\
\hline $\begin{array}{l}\text { Blinding (performance bias and detection } \\
\text { bias) } \\
\text { All outcomes }\end{array}$ & Low risk & $\begin{array}{l}\text { Identically labelled bottles that were recon- } \\
\text { stituted with water to } 4,000 \mathrm{~mL} \text { by study } \\
\text { personnel in the pharmacy. There was no } \\
\text { difference in the colour, appearance, or } \\
\text { taste among the different doses }\end{array}$ \\
\hline $\begin{array}{l}\text { Incomplete outcome data (attrition bias) } \\
\text { All outcomes }\end{array}$ & Low risk & $\begin{array}{l}\text { Drop-outs were balanced across treatment } \\
\text { groups with similar reasons for withdrawal }\end{array}$ \\
\hline Selective reporting (reporting bias) & Low risk & Data reported appropriately \\
\hline Other bias & Low risk & None apparent \\
\hline
\end{tabular}

Perkin 1977

\begin{tabular}{l|l}
\hline Methods & Randomised controlled crossover trial of lactulose versus senna \\
\hline Participants & $\begin{array}{l}21 \text { children under } 15 \text { years of age with a history of greater than } 3 \text { weeks constipation } \\
\text { Children with organic causes of constipation were excluded }\end{array}$ \\
\hline Interventions & $\begin{array}{l}\text { Lactulose } 10-15 \mathrm{~mL} \text { per day or Senna } 10-20 \mathrm{~mL} \text { per day for } 1 \text { week, then } 1 \text { week with } \\
\text { no treatment and then patients switched to received the other treatment }\end{array}$
\end{tabular}

Outcomes

Stool consistency, number of stools per day and adverse events

Follow-up for 3 weeks

Osmotic and stimulant laxatives for the management of childhood constipation (Review) 
Perkin 1977 (Continued)

\begin{tabular}{|c|c|c|}
\hline Notes & & \\
\hline \multicolumn{3}{|l|}{ Risk of bias } \\
\hline Bias & Authors' judgement & Support for judgement \\
\hline $\begin{array}{l}\text { Random sequence generation (selection } \\
\text { bias) }\end{array}$ & Unclear risk & $\begin{array}{l}\text { Random number list, but method of cre- } \\
\text { ation not described }\end{array}$ \\
\hline Allocation concealment (selection bias) & Low risk & Assignments in sealed envelopes \\
\hline $\begin{array}{l}\text { Blinding (performance bias and detection } \\
\text { bias) } \\
\text { All outcomes }\end{array}$ & Unclear risk & $\begin{array}{l}\text { Although author describes that identical } \\
\text { bottles with no identification were used, } \\
\text { further detail to confirm blinding are not } \\
\text { given }\end{array}$ \\
\hline $\begin{array}{l}\text { Incomplete outcome data (attrition bias) } \\
\text { All outcomes }\end{array}$ & Low risk & $\begin{array}{l}\text { One participant from the senna group was } \\
\text { lost to follow-up }\end{array}$ \\
\hline Selective reporting (reporting bias) & Low risk & Data reported appropriately \\
\hline Other bias & Low risk & None apparent \\
\hline
\end{tabular}

\section{Pitzalis 1995}

\begin{tabular}{l|l}
\hline Methods & Randomised controlled trial comparing lactitol with lactulose \\
\hline Participants & $\begin{array}{l}42 \text { children aged } 8 \text { months }-16 \text { years old with less than } 3.5 \text { stools per week } \\
\text { Patients with other organic pathology were excluded }\end{array}$ \\
\hline Interventions & $\begin{array}{l}\text { Lacitol (Portolac zyma) } 250 \mathrm{mg} / \mathrm{kg} / \text { day single dose, could be increased to } 400 \mathrm{mg} / \mathrm{kg} / \\
\text { day } \\
\text { Lactulose (Epalfen zambon) } 500 \mathrm{mg} / \mathrm{kg} / \text { day single dose, could be increased to } 750 \mathrm{mg} / \\
\text { kg/day }\end{array}$ \\
\hline Outcomes & $\begin{array}{l}\text { Primary outcome measure was the frequency of defecation and secondary measures } \\
\text { included palatability and colonic transit time } \\
\text { Follow-up was for } 1 \mathrm{month}\end{array}$ \\
\hline Notes & Italian publication \\
\hline
\end{tabular}

\section{Risk of bias}

\begin{tabular}{ll} 
Bias Authors' judgement \\
\hline
\end{tabular}

Support for judgement

Random sequence generation (selection Unclear risk Not described bias) 


\section{Pitzalis 1995 (Continued)}

\begin{tabular}{l|ll}
\hline Allocation concealment (selection bias) & Unclear risk & Not described \\
\hline $\begin{array}{l}\text { Blinding (performance bias and detection } \\
\text { bias) } \\
\text { All outcomes }\end{array}$ & Unclear risk & Not described \\
\hline $\begin{array}{l}\text { Incomplete outcome data (attrition bias) } \\
\text { All outcomes }\end{array}$ & Low risk & 9 children did not complete the study \\
\hline Selective reporting (reporting bias) & High risk & No adverse events mentioned \\
\hline Other bias & Low risk & None apparent \\
\hline
\end{tabular}

\section{Quitadamo 2012}

Methods

Participants
Randomised, open label trial comparing PEG 3350 with electrolytes to a dietary fibre mix consisting of acacia, psyllium and fructose

100 children diagnosed with chronic functional constipation as defined by the Rome III criteria were enrolled in the study

Children with organic causes for constipation including Hirschsprung disease, spinal bifida (occulta), hypothyroidism or other metabolic or renal abnormalities, mental retardation, and children using lactulose or other laxatives, prebiotics or probiotics, in 4 weeks before the first visit were excluded

Interventions

PEG 3350 at a dose of $0.5 \mathrm{~g} / \mathrm{kg}$ per day (dose escalation up to $1 \mathrm{~g} / \mathrm{kg} /$ day allowed for children who did not improve after 3 days) for 8 weeks $(n=50)$

Dietary fibre mix at a dose of $16.8 \mathrm{~g} /$ day (dose escalation up to $22.4 \mathrm{~g} /$ day allowed for children who did not improve after 3 days) for 8 weeks $(n=50)$

Outcomes

Primary outcome: improvement of constipation, defined as: $>3$ bowel movements per week, $>2$ stool consistency grade on Bristol Stool Form Scale, absence of fecal incontinence, abdominal pain, pain on defecation, and fecal bleeding

Secondary outcomes: nausea, vomiting, and flatulence, safety profile, and patient's acceptance and compliance

Follow-up occurred at 1, 2, 4, and 8 weeks after entry

Notes

Risk of bias

Bias

Random sequence generation (selection Unclear risk bias)
Authors' judgement

\section{Support for judgement}

Children were then randomly assigned into 2 groups according to an automatically generated randomisation list

How the list was generated was not described 


\section{Quitadamo 2012 (Continued)}

\begin{tabular}{|c|c|c|}
\hline Allocation concealment (selection bias) & Unclear risk & Not described \\
\hline $\begin{array}{l}\text { Blinding (performance bias and detection } \\
\text { bias) } \\
\text { All outcomes }\end{array}$ & High risk & Open label \\
\hline $\begin{array}{l}\text { Incomplete outcome data (attrition bias) } \\
\text { All outcomes }\end{array}$ & Unclear risk & $\begin{array}{l}14 \text { children dropped out from the dietary } \\
\text { mix fibre group (all due to bad taste) com- } \\
\text { pared to } 3 \text { children in the PEG } 3350 \text { group } \\
\text { ( } 2 \text { due to bad taste and } 1 \text { lost to follow-up) }\end{array}$ \\
\hline Selective reporting (reporting bias) & Low risk & Data reported appropriately \\
\hline Other bias & Low risk & None apparent \\
\hline
\end{tabular}

\section{Rafati 2011}

Methods

Randomised controlled trial comparing PEG with liquid paraffin

Participants

158 children aged 2 to 12 years with a history of functional constipation

Interventions

$1.0-1.5 \mathrm{~g} / \mathrm{kg} /$ day PEG 3350 or $1.0-1.5 \mathrm{ml} / \mathrm{kg} /$ day liquid paraffin orally for 4 months PEG 3350 powder was prepared as a $40 \%$ solution to trust reliable to apply the paediatric dosing and to increase compliance and liquid paraffin was provided from a pharmaceutical factory

For rectal disimpaction, bisacodyl suppositories were applied at the beginning of the study

Outcomes

Primary outcomes were stool and encopresis frequency per week

Notes

\section{Risk of bias}

\begin{tabular}{l|l|l} 
Bias & Authors' judgement & Support for judgement \\
\hline $\begin{array}{l}\text { Random sequence generation (selection } \\
\text { bias) }\end{array}$ & Unclear risk & Not described \\
\hline Allocation concealment (selection bias) & Unclear risk & Not described \\
\hline $\begin{array}{l}\text { Blinding (performance bias and detection } \\
\text { bias) } \\
\text { All outcomes }\end{array}$ & Unclear risk & Not described \\
\hline
\end{tabular}

Incomplete outcome data (attrition bias) High risk

Dropouts are not explained All outcomes 
Rafati 2011 (Continued)

\begin{tabular}{lll}
\hline Selective reporting (reporting bias) & High risk & No adverse event data reported \\
\hline Other bias & Low risk & None apparent \\
\hline
\end{tabular}

Ratanamongkol 2009

\begin{tabular}{l|l}
\hline Methods & $\begin{array}{l}\text { Randomised controlled trial comparing PEG } 4000 \text { without electrolytes to milk of mag- } \\
\text { nesia }\end{array}$ \\
\hline Participants & $\begin{array}{l}94 \text { infants and children aged one-four years } \\
\text { Patients with organic causes for their constipation or renal insufficiency were excluded }\end{array}$ \\
\hline Interventions & $\begin{array}{l}\text { PEG } 4000 \text { without electrolytes, } 0.5 \mathrm{~g} / \mathrm{kg} / \text { day, maximal does } 1 \mathrm{~g} / \mathrm{kg} / \mathrm{day} \text { or milk of mag- } \\
\text { nesia suspension, } 400 \mathrm{mg} / 5 \mathrm{~mL}, 0.5 \mathrm{~mL} / \mathrm{kg} / \mathrm{day} \text {, maximal does } 3 \mathrm{~mL} / \mathrm{kg} / \mathrm{day}\end{array}$ \\
\hline Outcomes & $\begin{array}{l}\text { The primary outcome measure was the improvement rate, defined as the proportion of } \\
\text { patients who had }>\text { three bowel movements per week, }<\text { two episodes of faecal inconti- } \\
\text { nence per month, and no painful defecation, with or without laxative therapy } \\
\text { Secondary outcomes included: } 1) \text { improvement in stool frequency per week; } 2) \text { the } \\
\text { proportion of the patients who had any adverse effects; and } 3) \text { the compliance rate, } \\
\text { defined as the proportion of patients who received more than } 80 \% \text { of the medication } \\
\text { Follow-up was for } 4 \text { weeks }\end{array}$ \\
\hline Notes & \begin{tabular}{l} 
Fon \\
\hline
\end{tabular} \\
\hline
\end{tabular}

\section{Risk of bias}

\begin{tabular}{|c|c|c|}
\hline Bias & Authors' judgement & Support for judgement \\
\hline $\begin{array}{l}\text { Random sequence generation (selection } \\
\text { bias) }\end{array}$ & Low risk & Computer generated random number list \\
\hline Allocation concealment (selection bias) & Low risk & $\begin{array}{l}\text { Sealed opaque assignment envelopes se- } \\
\text { quentially opened }\end{array}$ \\
\hline $\begin{array}{l}\text { Blinding (performance bias and detection } \\
\text { bias) } \\
\text { All outcomes }\end{array}$ & Unclear risk & Not clear whether this was a blinded study \\
\hline $\begin{array}{l}\text { Incomplete outcome data (attrition bias) } \\
\text { All outcomes }\end{array}$ & Low risk & $\begin{array}{l}\text { There was one drop out in the PEG group } \\
\text { compared to four in the milk of magnesia } \\
\text { group }\end{array}$ \\
\hline Selective reporting (reporting bias) & Low risk & Data reported appropriately \\
\hline Other bias & Low risk & None apparent \\
\hline
\end{tabular}


Saneian 2012

Methods

Participants

Interventions
Randomised controlled trial comparing PEG magnesium hydroxide, and lactulose

75 children aged 1 to 6 -years with functional chronic constipation

Those with organic pathology were excluded

Lactose (Tolid Daroo, Tehran, Iran) $1 \mathrm{cc} / \mathrm{kg} / \mathrm{day}$ for one month $(\mathrm{n}=25)$ - dose could be increased up to $3 \mathrm{cc} / \mathrm{kg} /$ day

Magnesium hydroxide (Tolid Daroo, Tehran, Iran) $1 \mathrm{cc} / \mathrm{kg} /$ day for one month $(\mathrm{n}=25)$

- dose could be increased up to $3 \mathrm{cc} / \mathrm{kg} /$ day

PEG with no electrolyte 40\% (School of Pharmacy, Shiraz University of Medical Sciences, Shiraz, Iran) $1 \mathrm{cc} / \mathrm{kg} /$ day for one month $(\mathrm{n}=25)$ - dose could be increased up to $3 \mathrm{cc} /$ $\mathrm{kg} /$ day

Outcomes

Therapeutic result defined as defecation equal to or more than 3 times per week without pain and bleeding and fecal incontinence less than twice a month at the end of one month treatment

Stool frequency per week, disimpaction, need to change therapy, adverse events, parent and patient satisfaction

Follow-up occurred one week after end of treatment and once per month for 4 to 6 months

Notes

Risk of bias

Bias

Random sequence generation (selection Low risk bias)
Authors' judgement
Support for judgement

Computer generated randomisation: the sample size calculated 75 subjects divided in three 25-subject groups by systematic randomisation using the randomisation software

\section{Not described}

Blinding was not described

However, none of the patients received placebo

Not described

Data reported appropriately

None apparent 
Methods

Participants

Interventions

Outcomes

Notes

Risk of bias

\begin{tabular}{l|ll}
\hline Bias & Authors' judgement & Support for judgement \\
\hline $\begin{array}{l}\text { Random sequence generation (selection } \\
\text { bias) }\end{array}$ & Low risk & Computer generated random number list \\
\hline $\begin{array}{l}\text { Allocation concealment (selection bias) } \\
\text { Blinding (performance bias and detection } \\
\text { bias) } \\
\text { All outcomes }\end{array}$ & Low risk & Sealed opaque envelopes used \\
\hline $\begin{array}{l}\text { Incomplete outcome data (attrition bias) } \\
\text { All outcomes }\end{array}$ & Low risk & Described and appropriate \\
\hline $\begin{array}{l}\text { Selective reporting (reporting bias) } \\
\text { Other bias }\end{array}$ & Low risk & $\begin{array}{l}\text { Two participants dropped out of each } \\
\text { group }\end{array}$ \\
\hline
\end{tabular}

Randomised controlled double blind crossover trial comparing PEG 3350 with electrolytes versus placebo

51 children aged 24 months to 11 years were eligible for enrolment

Constipation was defined according to the Rome criteria

Children were excluded from the study if they had current or previous faecal impaction or organic pathology causing their constipation Also, if they were currently receiving doses of stimulant laxatives considered by local observers to be at the higher end of their own dose spectrum (senna or sodium picosulphate) with no effect, having assessed to their clinical satisfaction adequate compliance

Placebo or PEG 3350 with electrolytes (Movicol, Norgine Pharnaceuticals, UK)]

The dosing regimen was based on age and clinical response

Participants received 2 weeks of therapy, followed by a 2 week washout period and then a further 2 weeks with the alternate therapy

The primary efficacy variable was the mean number of complete defecations per week Secondary efficacy variables included the total number of complete and incomplete defecations per week, pain on defecation, straining on defecation, faecal incontinence, stool consistency, and a global assessment of treatment by the investigator and by the child or his or her parent or guardian, as well as recording of adverse events

Follow-up for 6 weeks 
Tolia 1993

\begin{tabular}{|c|c|c|}
\hline Methods & \multicolumn{2}{|c|}{$\begin{array}{l}\text { Randomised controlled open trial comparing PEG } 3350 \text { with mineral oil (liquid paraffin) } \\
\text { for the treatment of faecal impaction }\end{array}$} \\
\hline Participants & \multicolumn{2}{|c|}{$\begin{array}{l}36 \text { children older than } 2 \text { years in age with constipation were potentially acceptable for } \\
\text { the study } \\
\text { Patients were excluded if they had any other organic cause for their impaction. physical } \\
\text { examination by the presence of firm to hard faecal impaction in the anal canal and rectal } \\
\text { ampulla on an otherwise normal complete initial physical examination }\end{array}$} \\
\hline Interventions & \multicolumn{2}{|c|}{$\begin{array}{l}\text { PEG } 3350 \text { (Colyte, } 20 \mathrm{~mL} / \mathrm{kg} / \text { hour for } 4 \text { hours) on two days or } 30 \mathrm{~mL} / 10 \mathrm{~kg} \text { of mineral } \\
\text { oil twice a day for two days } \\
\text { Those receiving PEG had a single dose of metoclopramide }\end{array}$} \\
\hline Outcomes & \multicolumn{2}{|c|}{$\begin{array}{l}\text { Outcomes included time to first stool, frequency of stool movements, consistency, dis- } \\
\text { tention, cramps, nausea and vomiting, as well as side effectsFollow-up were after two } \\
\text { days }\end{array}$} \\
\hline \multicolumn{3}{|l|}{ Notes } \\
\hline \multicolumn{3}{|l|}{ Risk of bias } \\
\hline Bias & Authors' judgement & Support for judgement \\
\hline $\begin{array}{l}\text { Random sequence generation (selection } \\
\text { bias) }\end{array}$ & Low risk & Computer generated random number list \\
\hline Allocation concealment (selection bias) & Unclear risk & Not described \\
\hline $\begin{array}{l}\text { Blinding (performance bias and detection } \\
\text { bias) } \\
\text { All outcomes }\end{array}$ & High risk & Open label \\
\hline $\begin{array}{l}\text { Incomplete outcome data (attrition bias) } \\
\text { All outcomes }\end{array}$ & Low risk & $\begin{array}{l}\text { Drop-outs were balanced across treatment } \\
\text { groups with similar reasons for withdrawal }\end{array}$ \\
\hline Selective reporting (reporting bias) & Low risk & Data reported appropriately \\
\hline Other bias & Low risk & None apparent \\
\hline
\end{tabular}

\section{Treepongkaruna 2014}

Methods

Participants
Randomised double-blind trial comparing PEG 4000 and lactulose

88 children aged between 12 to 36 months with a diagnosis of chronic functional constipation based on a modification of the Rome II criteria for infants and preschool children

Those with organic pathology were excluded 


\section{Treepongkaruna 2014 (Continued)}

\begin{tabular}{|c|c|c|}
\hline Interventions & \multicolumn{2}{|c|}{$\begin{array}{l}\text { Lactulose }(3.3 \text { g per day) for } 4 \text { weeks }(n=44) \\
\text { PEG } 4000 \text { (Forlax®; } 8 \text { g per day) for } 4 \text { weeks. }(n=44)\end{array}$} \\
\hline Outcomes & \multicolumn{2}{|c|}{$\begin{array}{l}\text { Primary outcome: stool frequency at week } 4 \\
\text { Secondary outcomes: stool consistency, ease of stool passage and the occurrence of sub- } \\
\text { jective symptoms associated with defecation, including cramping, flatus, anal irritation, } \\
\text { adverse events and serious adverse events } \\
\text { Patients were followed up at weeks } 2 \text { and } 4\end{array}$} \\
\hline \multicolumn{3}{|l|}{ Notes } \\
\hline \multicolumn{3}{|l|}{ Risk of bias } \\
\hline Bias & Authors' judgement & Support for judgement \\
\hline $\begin{array}{l}\text { Random sequence generation (selection } \\
\text { bias) }\end{array}$ & Low risk & $\begin{array}{l}\text { Treatment was allocated using a randomi- } \\
\text { sation list of treatment allocation codes pre- } \\
\text { pared by the contract research organisation } \\
\text { responsible for operational management of } \\
\text { the study }\end{array}$ \\
\hline Allocation concealment (selection bias) & Unclear risk & Not described \\
\hline $\begin{array}{l}\text { Blinding (performance bias and detection } \\
\text { bias) } \\
\text { All outcomes }\end{array}$ & Low risk & $\begin{array}{l}\text { Double-blind, double-dummy } \\
\text { All sachets were similar in size, colour, } \\
\text { smell, taste and appearance in order to en- } \\
\text { sure adequate blinding of the study medi- } \\
\text { cation }\end{array}$ \\
\hline $\begin{array}{l}\text { Incomplete outcome data (attrition bias) } \\
\text { All outcomes }\end{array}$ & Low risk & $\begin{array}{l}\text { Drop outs were balanced across interven- } \\
\text { tion groups with similar reasons for with- } \\
\text { drawal }\end{array}$ \\
\hline Selective reporting (reporting bias) & Low risk & Data reported appropriately \\
\hline Other bias & Low risk & None apparent \\
\hline
\end{tabular}

\section{Urganci 2005}

\begin{tabular}{ll} 
Methods & Randomised open label trial of liquid paraffin versus lactulose \\
\hline Participants & $\begin{array}{l}40 \text { children } 2 \text { to } 12 \text { years old with constipation with evidence of faecal impaction were } \\
\text { enrolled in the study } \\
\text { Children with organic pathology were excluded }\end{array}$
\end{tabular}

Interventions

Liquid paraffin or lactulose $1 \mathrm{ml} / \mathrm{kg}$, twice daily for each drug

For determination of the best dose for each child, parents were asked to increase or 
decrease the volume of each drug by $25 \%$ every 3 days as required, to yield two firmloose stools per day

The maximum dose used throughout the study was $3 \mathrm{~mL} / \mathrm{kg}$ per day for each drug All participants received behavioural advice and saw a nutritionist

Outcomes

Notes
Primary outcome was effective treatment, defined as clearance of the impaction (more than three bowel movements per week and improvement in stool consistency)

Secondary outcomes included stool frequency and stool consistency in first 4 weeks and last 4 weeks, as well as adverse events

Follow-up was for 8 weeks

\section{Risk of bias}

\begin{tabular}{|c|c|c|}
\hline Bias & Authors' judgement & Support for judgement \\
\hline $\begin{array}{l}\text { Random sequence generation (selection } \\
\text { bias) }\end{array}$ & Unclear risk & Not described \\
\hline Allocation concealment (selection bias) & Unclear risk & Not described \\
\hline $\begin{array}{l}\text { Blinding (performance bias and detection } \\
\text { bias) } \\
\text { All outcomes }\end{array}$ & High risk & Open label \\
\hline $\begin{array}{l}\text { Incomplete outcome data (attrition bias) } \\
\text { All outcomes }\end{array}$ & Low risk & No drop outs \\
\hline Selective reporting (reporting bias) & Low risk & Data reported appropriately \\
\hline Other bias & Low risk & None apparent \\
\hline
\end{tabular}

Ustundag 2010

Methods

Participants

Interventions
Randomised trial comparing partially hydrolyzed guar gum (PHGG) to lactulose

68 children 4 to 16 years old with constipation (Rome III) were enrolled in the study Those with organic pathology were excluded

Lactulose $(1 \mathrm{ml} / \mathrm{kg} /$ day, in divided doses; $\mathrm{n}=33)$ PHGG $(\mathrm{n}=35)$ for children between 4-6 years: $3 \mathrm{~g} /$ day; 6-12 years: $4 \mathrm{~g} /$ day; and $12-16$ years: $5 \mathrm{~g} /$ day

All patients received treatment for 4 weeks

Primary outcome: frequency of defecation (number of stools per week)

Secondary outcomes: stool consistency, abdominal pain, stool withholding, rectal bleeding, adverse events, and family questionnaire (satisfaction with success of treatment and adverse effects) 
Ustundag 2010 (Continued)

Follow-up occurred at 4 weeks

\begin{tabular}{|c|c|c|}
\hline Notes & & \\
\hline \multicolumn{3}{|l|}{ Risk of bias } \\
\hline Bias & Authors' judgement & Support for judgement \\
\hline $\begin{array}{l}\text { Random sequence generation (selection } \\
\text { bias) }\end{array}$ & Unclear risk & Not described \\
\hline Allocation concealment (selection bias) & Unclear risk & Not described \\
\hline $\begin{array}{l}\text { Blinding (performance bias and detection } \\
\text { bias) } \\
\text { All outcomes }\end{array}$ & Unclear risk & Not described \\
\hline $\begin{array}{l}\text { Incomplete outcome data (attrition bias) } \\
\text { All outcomes }\end{array}$ & Low risk & $\begin{array}{l}\text { During the treatment period, } 7 \text { patients } \\
\text { dropped out ( } 4 \text { from the PHGG group, } 3 \\
\text { from the lactulose group) }\end{array}$ \\
\hline Selective reporting (reporting bias) & Unclear risk & $\begin{array}{l}\text { Adverse events were not adequately re- } \\
\text { ported }\end{array}$ \\
\hline Other bias & Low risk & None apparent \\
\hline
\end{tabular}

Voskuj1 2004

Methods

Participants

Interventions
Randomised double blind trial comparing PEG 3350 with lactulose

100 children aged six month to 15 years were included in this study Children with an organic cause for their constipation were excluded

Patients had a 1 week run in and then received daily rectal enemas for 3 days $(<6$ years of age received $60 \mathrm{ml} \mathrm{Klyx}$ (sodium dioctylsulfosuccinate and sorbitol) while those $>6$ years of age received $120 \mathrm{ml}$ Klyx)

Lactulose (6 g (sachet)) versus PEG 3350 (2.95 g (sachet)) 1 sachet per day under 6 starting, 2 over 6 - children were reassessed at 1 week and either increase by 1 sachet or decreased by $50 \%$

Outcomes
The primary outcomes were frequency of stools, frequency of encopresis, and overall treatment success at eight weeks

An increase in defecation frequency was considered to have improved if it rose to three or more times a week while encopresis had to decrease to an incidence of one episode or less every two weeks

The incidence of adverse events was also documented Follow-up was for 8 weeks 
Voskujl 2004 (Continued)

Notes

Risk of bias

\begin{tabular}{|c|c|c|}
\hline Bias & Authors' judgement & Support for judgement \\
\hline $\begin{array}{l}\text { Random sequence generation (selection } \\
\text { bias) }\end{array}$ & Unclear risk & Not described \\
\hline Allocation concealment (selection bias) & Unclear risk & Not described \\
\hline $\begin{array}{l}\text { Blinding (performance bias and detection } \\
\text { bias) } \\
\text { All outcomes }\end{array}$ & Low risk & $\begin{array}{l}\text { Identical sachets, released by central phar- } \\
\text { macy }\end{array}$ \\
\hline $\begin{array}{l}\text { Incomplete outcome data (attrition bias) } \\
\text { All outcomes }\end{array}$ & Low risk & $\begin{array}{l}\text { Drop outs were balanced across interven- } \\
\text { tion groups with similar reasons for with- } \\
\text { drawal }\end{array}$ \\
\hline Selective reporting (reporting bias) & Low risk & Data reported appropriately \\
\hline Other bias & Low risk & None apparent \\
\hline
\end{tabular}

Wang 2007

Methods

Participants

Interventions

Outcomes
Randomised controlled multi-centre trial comparing PEG 4000 with lactulose

216 children from $8-18$ years old

Children with other organic disease were excluded

PEG 4000 ( $n=105)$ : Forlax, 2 sachets $x 20$ g/day for 2 weeks

Lactulose ( $\mathrm{n}=111): 15 \mathrm{~mL} /$ day, then drop to $10 \mathrm{~mL}$ after 3 days) for 2 weeks

Primary outcome was frequency of bowel movements

Secondary outcomes included stool consistency, abdominal symptoms and safety

Follow-up was for 2 weeks

Chinese publication

\section{Risk of bias}

\section{Bias}

Random sequence generation (selection Low risk bias)

Allocation concealment (selection bias)
Unclear risk

Authors' judgement

Osmotic and stimulant laxatives for the management of childhood constipation (Review)

Copyright @ 2016 The Cochrane Collaboration. Published by John Wiley \& Sons, Ltd.

\section{Support for judgement}

A biostatistician constructed random digit tables using statistical software SAS v8.2

Not described 


\begin{tabular}{l|l|l}
\hline $\begin{array}{l}\text { Blinding (performance bias and detection } \\
\text { bias) } \\
\text { All outcomes }\end{array}$ & Unclear risk & Not described \\
\hline $\begin{array}{l}\text { Incomplete outcome data (attrition bias) } \\
\text { All outcomes }\end{array}$ & Unclear risk & Drop outs were not described \\
\hline Selective reporting (reporting bias) & Low risk & Data reported appropriately \\
\hline Other bias & Low risk & None apparent \\
\hline
\end{tabular}

PEG: polyethylene glycol.

Characteristics of excluded studies [ordered by study ID]

\begin{tabular}{|c|c|}
\hline Study & Reason for exclusion \\
\hline Bekkali 2011 & $\begin{array}{l}\text { Abstract publication } \\
\text { Trial compared one formulation of PEG to another (i.e. PEG } 3350 \text { with electrolytes versus PEG 4000) }\end{array}$ \\
\hline Berg 1983 & $\begin{array}{l}\text { Study does not include patients with functional constipation } \\
\text { Patients were diagnosed with functional soiling }\end{array}$ \\
\hline Bongers 2009 & $\begin{array}{l}\text { All patients received PEG } \\
\text { Trial compared enemas + PEG to PEG }\end{array}$ \\
\hline Connolly 1974 & $\begin{array}{l}\text { Trial included adult and paediatric patients and did not report separate results for children } \\
\text { Trial compared an osmotic laxative (lactulose) to a stimulant laxative (i.e. senna, anthraquinone derivatives or } \\
\text { bisacodyl) }\end{array}$ \\
\hline Corazziari 1996 & Not a paediatric study \\
\hline Dehghani 2014 & $\begin{array}{l}\text { All patients received PEG } \\
\text { Trial compared oral domperidone + PEG to PEG }\end{array}$ \\
\hline Dupont 2006 & Not a RCT, no comparison group \\
\hline Ferguson 1999 & Not a paediatric study \\
\hline Hardikar 2007 & Not a RCT, no comparison group \\
\hline Hejl 1990 & Not a RCT, no comparison group \\
\hline
\end{tabular}


(Continued)

\begin{tabular}{ll}
\hline Kazak 1999 & Children had underlying pathology \\
\hline Khoshoo 2006 & $\begin{array}{l}\text { All patients received PEG 3350 } \\
\text { Trial compared tegaserod + PEG 3350 to PEG 3350 }\end{array}$ \\
\hline Miller 2012 & The trial focused on the treatment of faecal impaction rather than treatment of constipation \\
\hline Ormarsson 2013 & $\begin{array}{l}\text { Abstract publication } \\
\text { Trial compared marine lipid suppositories to docusate sodium and sorbitol enema }\end{array}$ \\
\hline Savino 2012 & Trial compared one formulation of PEG to another (i.e. PEG-only formulation compared to PEG with electrolytes) \\
\hline Shevtsov 2005 & Not a RCT \\
\hline Sonheimer 1982 & Not a RCT \\
\hline Youssef 2002 & The trial focused on the treatment of faecal impaction rather than treatment of constipation \\
\hline
\end{tabular}

PEG: polyethylene glycol.

RCT: randomised controlled trial 
DATA AND ANALYSES

Comparison 1. PEG versus placebo

\begin{tabular}{lcclll} 
Outcome or subgroup title & $\begin{array}{c}\text { No. of } \\
\text { studies }\end{array}$ & $\begin{array}{c}\text { No. of } \\
\text { participants }\end{array}$ & Statistical method & Effect size \\
\hline 1 Frequency of defecation & 2 & 101 & Mean Difference (IV, Random, 95\% CI) & $2.61[1.15,4.08]$ \\
2 Serious adverse events & 2 & 101 & Risk Ratio (M-H, Random, 95\% CI) & $0.19[0.02,1.63]$ \\
\hline
\end{tabular}

Comparison 2. PEG versus Lactulose

\begin{tabular}{lccll} 
Outcome or subgroup title & $\begin{array}{c}\text { No. of } \\
\text { studies }\end{array}$ & $\begin{array}{c}\text { No. of } \\
\text { participants }\end{array}$ & \multicolumn{1}{c}{ Statistical method } & Effect size \\
\hline 1 Frequency of defecation & 6 & 465 & Mean Difference (IV, Random, 95\% CI) & $0.70[0.10,1.31]$ \\
2 Need for additional therapies & 4 & 304 & Risk Ratio (M-H, Fixed, 95\% CI) & $0.55[0.36,0.83]$ \\
$\begin{array}{l}\text { 3 Need for additional therapies } \\
\quad \text { (sensitivity analysis) }\end{array}$ & 4 & 304 & Risk Ratio (M-H, Random, 95\% CI) & $0.59[0.33,1.04]$ \\
4 Successful disimpaction & 1 & 50 & Risk Ratio (M-H, Fixed, 95\% CI) & $1.24[1.01,1.53]$ \\
5 Adverse events & 3 & 242 & Risk Ratio (M-H, Fixed, 95\% CI) & $0.87[0.68,1.11]$ \\
6 Serious adverse events & 2 & 145 & Risk Ratio (M-H, Fixed, 95\% CI) & $2.43[0.37,15.96]$ \\
\hline
\end{tabular}

\section{Comparison 3. PEG versus Milk of Magnesia}

\begin{tabular}{lcclc} 
Outcome or subgroup title & $\begin{array}{c}\text { No. of } \\
\text { studies }\end{array}$ & $\begin{array}{c}\text { No. of } \\
\text { participants }\end{array}$ & Statistical method & Effect size \\
\hline $\begin{array}{l}\text { 1 Frequency of defecation } \\
\begin{array}{l}\text { Frequency of defecation } \\
\quad(\text { sensitivity analysis excluding }\end{array}\end{array}$ & 4 & 261 & Mean Difference (IV, Random, 95\% CI) & $0.20[-0.68,1.07]$ \\
$\quad \begin{array}{l}\text { outlier) } \\
3 \text { Successful disimpaction }\end{array}$ & 1 & 211 & Mean Difference (IV, Fixed, 95\% CI) & $0.69[0.48,0.89]$ \\
\hline
\end{tabular}

Osmotic and stimulant laxatives for the management of childhood constipation (Review) 


\begin{tabular}{lcclc} 
Outcome or subgroup title & $\begin{array}{c}\text { No. of } \\
\text { studies }\end{array}$ & $\begin{array}{c}\text { No. of } \\
\text { participants }\end{array}$ & Statistical method & Effect size \\
\hline 1 Frequency of defecation & 1 & 80 & Mean Difference (IV, Fixed, 95\% CI) & $1.00[-1.58,3.58]$ \\
2 Successful disimpaction & 1 & 90 & Risk Ratio (M-H, Fixed, 95\% CI) & $0.85[0.66,1.09]$ \\
\hline
\end{tabular}

Comparison 5. PEG versus Liquid Paraffin

\begin{tabular}{lcccc} 
Outcome or subgroup title & $\begin{array}{c}\text { No. of } \\
\text { studies }\end{array}$ & $\begin{array}{c}\text { No. of } \\
\text { participants }\end{array}$ & Statistical method & Effect size \\
\hline 1 Frequency of defecation & 2 & 261 & Mean Difference (IV, Fixed, 95\% CI) & $0.35[-0.24,0.95]$ \\
\hline
\end{tabular}

Comparison 6. PEG versus Flixweed

\begin{tabular}{lcclc} 
Outcome or subgroup title & $\begin{array}{c}\text { No. of } \\
\text { studies }\end{array}$ & $\begin{array}{c}\text { No. of } \\
\text { participants }\end{array}$ & Statistical method & Effect size \\
\hline 1 Frequency of defecation & 1 & 109 & Mean Difference (IV, Random, 95\% CI) & $0.0[-0.33,0.33]$ \\
2 Need for additional therapies & 1 & 109 & Risk Ratio (M-H, Fixed, 95\% CI) & $3.52[1.03,12.10]$ \\
\hline
\end{tabular}

Comparison 7. PEG versus Dietary fibre mix

\begin{tabular}{lccll} 
Outcome or subgroup title & $\begin{array}{c}\text { No. of } \\
\text { studies }\end{array}$ & $\begin{array}{c}\text { No. of } \\
\text { participants }\end{array}$ & Statistical method & Effect size \\
\hline 1 Frequency of defecation & 1 & 83 & Mean Difference (IV, Fixed, 95\% CI) & $0.20[-0.64,1.04]$ \\
2 Need for additional therapy & 1 & 100 & Risk Ratio (M-H, Fixed, 95\% CI) & $0.5[0.05,5.34]$ \\
3 Frequency of faecal incontinence & 1 & 83 & Mean Difference (IV, Fixed, 95\% CI) & $-0.10[-0.62,0.42]$ \\
\hline
\end{tabular}




\begin{tabular}{lccll} 
Outcome or subgroup title & $\begin{array}{c}\text { No. of } \\
\text { studies }\end{array}$ & $\begin{array}{c}\text { No. of } \\
\text { participants }\end{array}$ & \multicolumn{1}{c}{ Statistical method } & Effect size \\
\hline 1 Frequency of defecation & 1 & 90 & Mean Difference (IV, Fixed, 95\% CI) & $1.30[0.76,1.84]$ \\
2 Need for additional therapy & 1 & 90 & Risk Ratio (M-H, Fixed, 95\% CI) & $0.49[0.24,1.02]$ \\
3 Faecal incontinence & 1 & 90 & Risk Ratio (M-H, Fixed, 95\% CI) & $0.17[0.02,1.39]$ \\
4 Adverse events & 1 & 90 & Risk Ratio (M-H, Fixed, 95\% CI) & $1.39[0.33,5.88]$ \\
\hline
\end{tabular}

\section{Comparison 9. Liquid Paraffin versus Lactulose}

\begin{tabular}{lccccc} 
Outcome or subgroup title & $\begin{array}{c}\text { No. of } \\
\text { studies }\end{array}$ & $\begin{array}{c}\text { No. of } \\
\text { participants }\end{array}$ & Statistical method & Effect size \\
\hline 1 Frequency of defecation & 2 & 287 & Mean Difference (IV, Fixed, 95\% CI) & $4.94[4.28,5.61]$ \\
\hline
\end{tabular}

Comparison 10. Lactulose versus Lactitol

\begin{tabular}{lcccc} 
Outcome or subgroup title & $\begin{array}{c}\text { No. of } \\
\text { studies }\end{array}$ & $\begin{array}{c}\text { No. of } \\
\text { participants }\end{array}$ & Statistical method & Effect size \\
\hline 1 Frequency of defecation & 1 & 42 & Mean Difference (IV, Fixed, 95\% CI) & $-0.80[-2.63,1.03]$ \\
\hline
\end{tabular}

Comparison 11. Lactulose versus Milk of Magnesia

\begin{tabular}{lccll} 
Outcome or subgroup title & $\begin{array}{c}\text { No. of } \\
\text { studies }\end{array}$ & $\begin{array}{c}\text { No. of } \\
\text { participants }\end{array}$ & \multicolumn{1}{c}{ Statistical method } & Effect size \\
\hline 1 Frequency of defecation & 1 & 50 & Mean Difference (IV, Fixed, 95\% CI) & $-1.51[-2.63,-0.39]$ \\
2 Need for additional therapy & 1 & 50 & Risk Ratio (M-H, Fixed, 95\% CI) & $2.0[0.80,5.02]$ \\
3 Successful disimpaction & 1 & 50 & Risk Ratio (M-H, Fixed, 95\% CI) & $0.83[0.67,1.03]$ \\
\hline
\end{tabular}




\begin{tabular}{lccccc} 
Outcome or subgroup title & $\begin{array}{c}\text { No. of } \\
\text { studies }\end{array}$ & $\begin{array}{c}\text { No. of } \\
\text { participants }\end{array}$ & Statistical method & Effect size \\
\hline 1 Frequency of defecation & 1 & 61 & Mean Difference (IV, Fixed, 95\% CI) & $1.0[-1.80,3.80]$ \\
\hline
\end{tabular}

\section{Analysis I.I. Comparison I PEG versus placebo, Outcome I Frequency of defecation.}

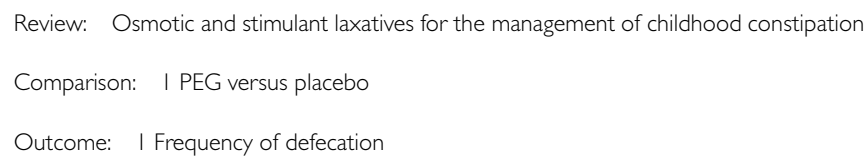

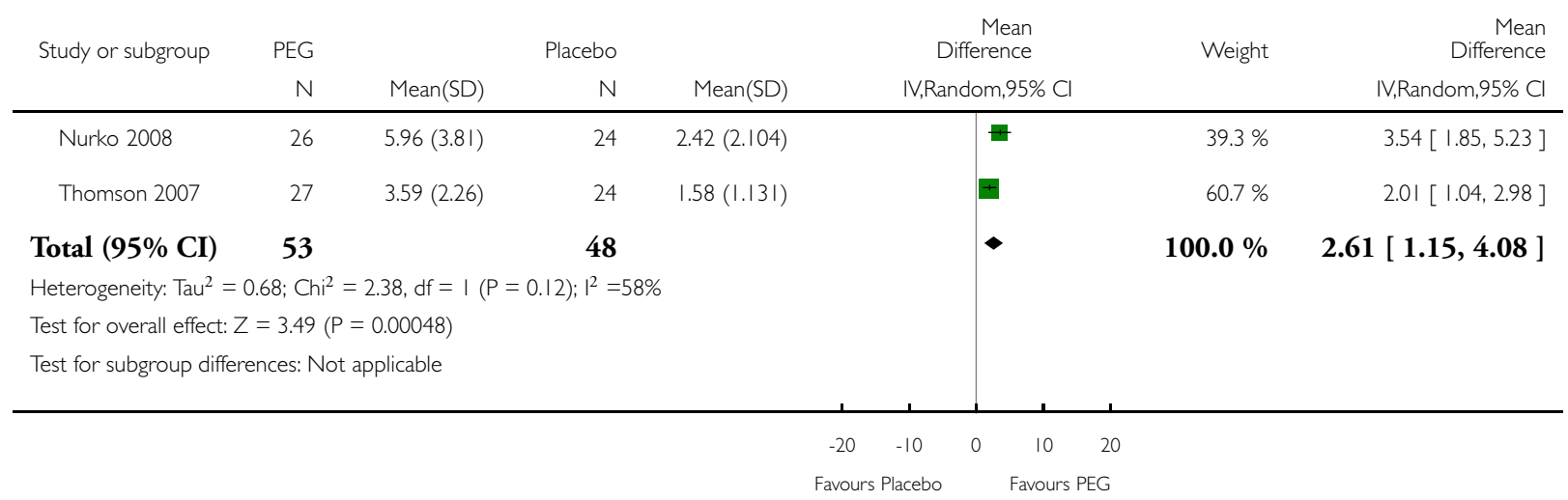




\section{Analysis I.2. Comparison I PEG versus placebo, Outcome 2 Serious adverse events.}

Review: Osmotic and stimulant laxatives for the management of childhood constipation

Comparison: I PEG versus placebo

Outcome: 2 Serious adverse events

\begin{tabular}{|c|c|c|c|c|c|}
\hline Study or subgroup & PEG & Placebo & $\begin{array}{r}\text { Risk Ratio } \\
\text { M- } \\
\text { H,Random,95\% } \\
\mathrm{Cl}\end{array}$ & Weight & $\begin{array}{c}\text { Risk Ratio } \\
\text { M- } \\
\text { H,Random,95\% } \\
\text { Cl }\end{array}$ \\
\hline Nurko 2008 & $0 / 26$ & $3 / 24$ & 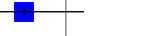 & $54.0 \%$ & $0.13[0.01,2.44]$ \\
\hline Thomson 2007 & $0 / 27$ & $1 / 24$ & $\rightarrow-12$ & $46.0 \%$ & $0.30[0.01,6.98]$ \\
\hline
\end{tabular}

Total (95\% CI)

53

48

$100.0 \%$

$0.19[0.02,1.63]$

Total events: 0 (PEG), 4 (Placebo)

Heterogeneity: $\operatorname{Tau}^{2}=0.0 ; \mathrm{Chi}^{2}=0.14, \mathrm{df}=\mathrm{I}(\mathrm{P}=0.7 \mathrm{I}) ; \mathrm{I}^{2}=0.0 \%$

Test for overall effect: $Z=1.51(P=0.13)$

Test for subgroup differences: Not applicable

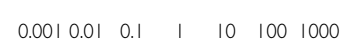

Favours PEG Favours Placebo 


\section{Analysis 2.I. Comparison 2 PEG versus Lactulose, Outcome I Frequency of defecation.}

Review: Osmotic and stimulant laxatives for the management of childhood constipation

Comparison: 2 PEG versus Lactulose

Outcome: I Frequency of defecation

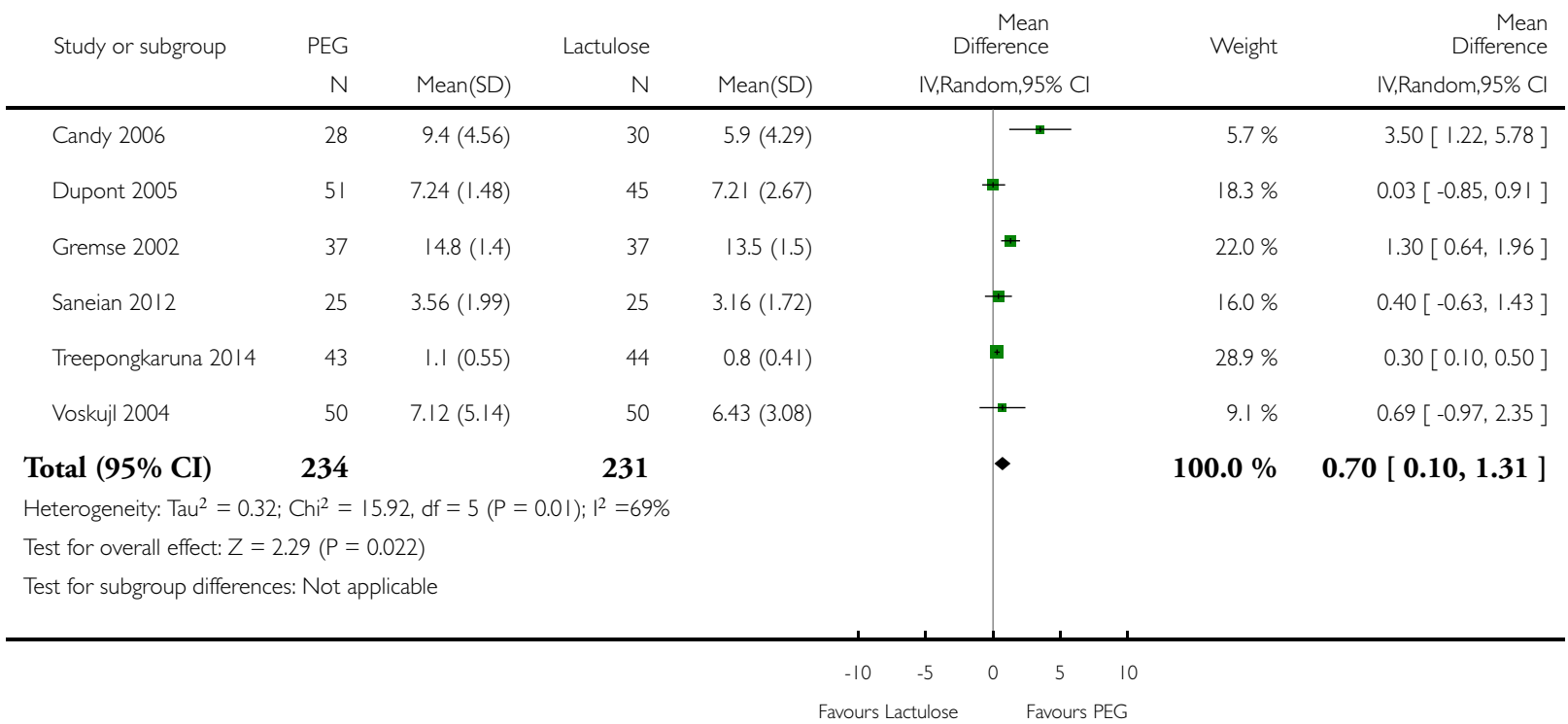




\section{Analysis 2.2. Comparison 2 PEG versus Lactulose, Outcome 2 Need for additional therapies.}

Review: Osmotic and stimulant laxatives for the management of childhood constipation

Comparison: 2 PEG versus Lactulose

Outcome: 2 Need for additional therapies

\begin{tabular}{|c|c|c|c|c|c|}
\hline \multirow[t]{2}{*}{ Study or subgroup } & PEG & Lactulose & Risk Ratio & Weight & Risk Ratio \\
\hline & $\mathrm{n} / \mathrm{N}$ & $n / N$ & M-H,Fixed,95\% Cl & & M-H,Fixed,95\% Cl \\
\hline Candy 2006 & $0 / 28$ & $8 / 30$ & $\longleftrightarrow$ & $17.0 \%$ & $0.06[0.00,1.04]$ \\
\hline Dupont 2005 & $|4 / 5|$ & $19 / 45$ & 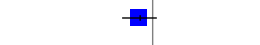 & $41.7 \%$ & $0.65[0.37,1.14]$ \\
\hline Saneian 2012 & $4 / 25$ & $10 / 25$ & $\longrightarrow$ & $20.7 \%$ & $0.40[0.14,1.11]$ \\
\hline Voskujl 2004 & $9 / 50$ & $10 / 50$ & $\rightarrow$ & $20.7 \%$ & $0.90[0.40,2.02]$ \\
\hline Total (95\% CI) & 154 & 150 & $<$ & $00.0 \%$ & {$[0.36,0.83]$} \\
\hline
\end{tabular}

Total events: 27 (PEG), 47 (Lactulose)

Heterogeneity: $\mathrm{Chi}^{2}=4.42, \mathrm{df}=3(\mathrm{P}=0.22) ; \mathrm{I}^{2}=32 \%$

Test for overall effect: $Z=2.85(P=0.0044)$

Test for subgroup differences: Not applicable

$100.0 \%$

$0.55[0.36,0.83$ ] 
Analysis 2.3. Comparison 2 PEG versus Lactulose, Outcome 3 Need for additional therapies (sensitivity analysis).

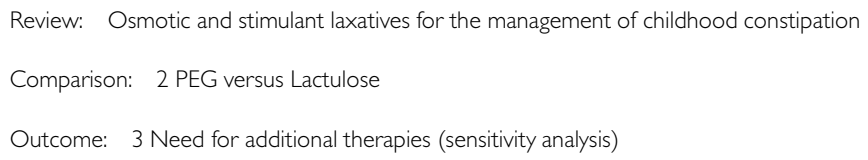

$\begin{array}{llllll} & & & C l & \\ \text { Candy } 2006 & 0 / 28 & 4 / 30 & 3.9 \% & 0.06[0.00,1.04]\end{array}$

Dupont $2005 \quad 14 / 51 \quad 19 / 45 \quad 0.65[0.37,1.14]$

Saneian $2012 \quad 4 / 25 \rightarrow-10 / 25 \quad 0.40[0.14,1.11]$

\begin{tabular}{|c|c|c|}
\hline Voskujl 2004 & $9 / 50$ & $10 / 50$ \\
\hline
\end{tabular}

Total $(95 \% \mathrm{CI})$

154

150

$100.0 \%$

$0.59[0.33,1.04]$

Total events: 27 (PEG), 47 (Lactulose)

Heterogeneity: Tau $^{2}=0.11 ; \mathrm{Chi}^{2}=4.42, \mathrm{df}=3(\mathrm{P}=0.22) ; \mathrm{I}^{2}=32 \%$

Test for overall effect: $Z=1.84(P=0.066)$

Test for subgroup differences: Not applicable

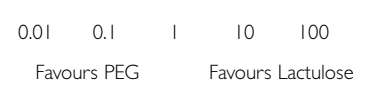

Analysis 2.4. Comparison 2 PEG versus Lactulose, Outcome 4 Successful disimpaction.

Review: Osmotic and stimulant laxatives for the management of childhood constipation

Comparison: 2 PEG versus Lactulose

Outcome: 4 Successful disimpaction

\begin{tabular}{|c|c|c|c|c|c|c|c|c|}
\hline \multirow[t]{2}{*}{ Study or subgroup } & PEG & Lactulose & \multicolumn{4}{|c|}{ Risk Ratio } & Weight & Risk Ratio \\
\hline & $\mathrm{n} / \mathrm{N}$ & $\mathrm{n} / \mathrm{N}$ & \multicolumn{4}{|c|}{ M-H,Fixed,95\% Cl } & & M-H,Fixed,95\% Cl \\
\hline Saneian 2012 & $25 / 25$ & $20 / 25$ & & & & & $100.0 \%$ & $1.24[1.01,1.53]$ \\
\hline Total (95\% CI) & 25 & 25 & & & $\bullet$ & & $100.0 \%$ & $1.24[1.01,1.53]$ \\
\hline \multicolumn{9}{|c|}{ Total events: 25 (PEG), 20 (Lactulose) } \\
\hline \multicolumn{9}{|c|}{ Heterogeneity: not applicable } \\
\hline \multicolumn{9}{|c|}{ Test for overall effect: $Z=2.07(P=0.038)$} \\
\hline \multicolumn{9}{|c|}{ Test for subgroup differences: Not applicable } \\
\hline & & & 0.01 & 0.1 & 10 & 100 & & \\
\hline \multicolumn{9}{|c|}{ Favours Lactulose } \\
\hline
\end{tabular}

Osmotic and stimulant laxatives for the management of childhood constipation (Review)

Copyright @ 2016 The Cochrane Collaboration. Published by John Wiley \& Sons, Ltd. 


\section{Analysis 2.5. Comparison 2 PEG versus Lactulose, Outcome 5 Adverse events.}

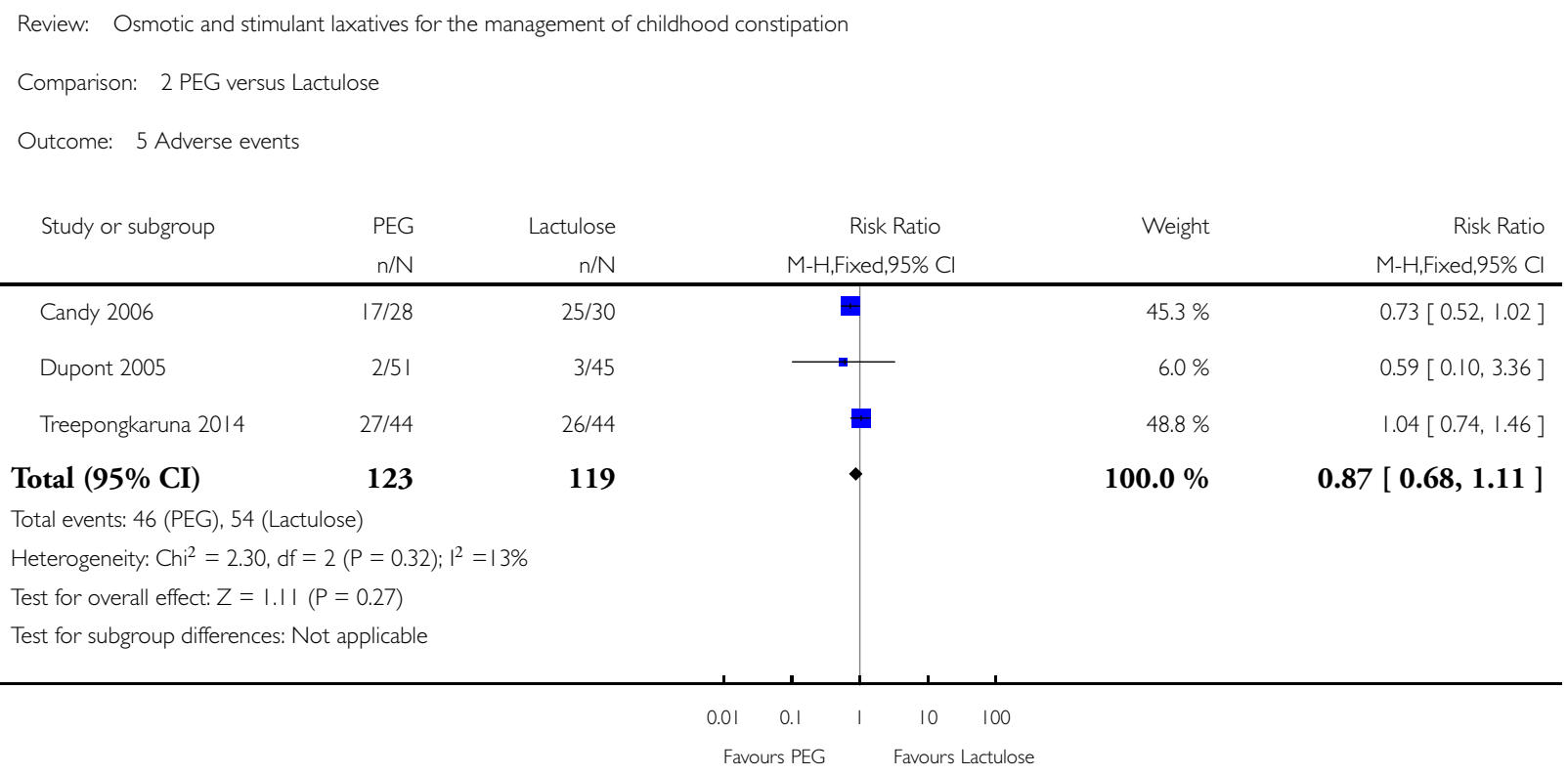




\section{Analysis 2.6. Comparison 2 PEG versus Lactulose, Outcome 6 Serious adverse events.}

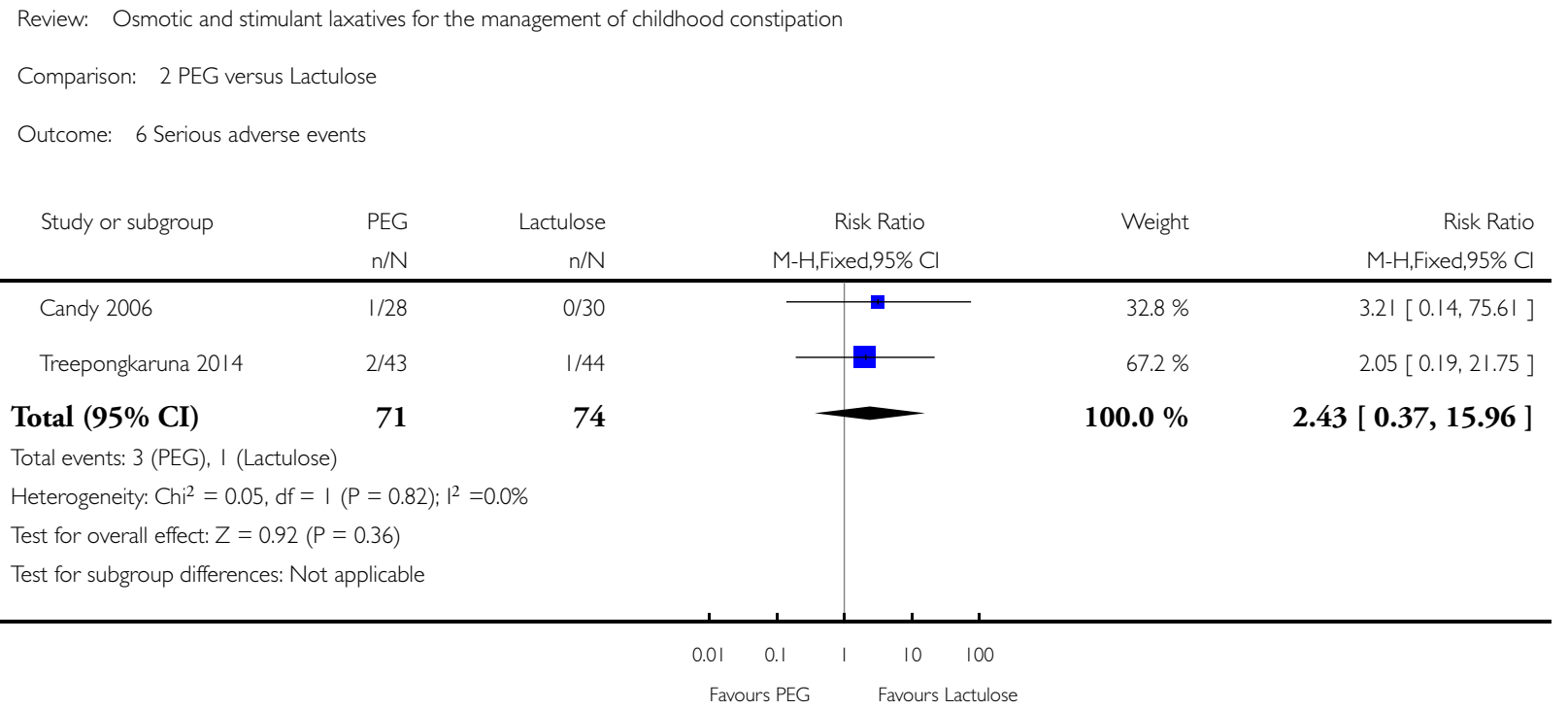

\section{Analysis 3.I. Comparison 3 PEG versus Milk of Magnesia, Outcome I Frequency of defecation.}

Review: Osmotic and stimulant laxatives for the management of childhood constipation

Comparison: 3 PEG versus Milk of Magnesia

Outcome: I Frequency of defecation

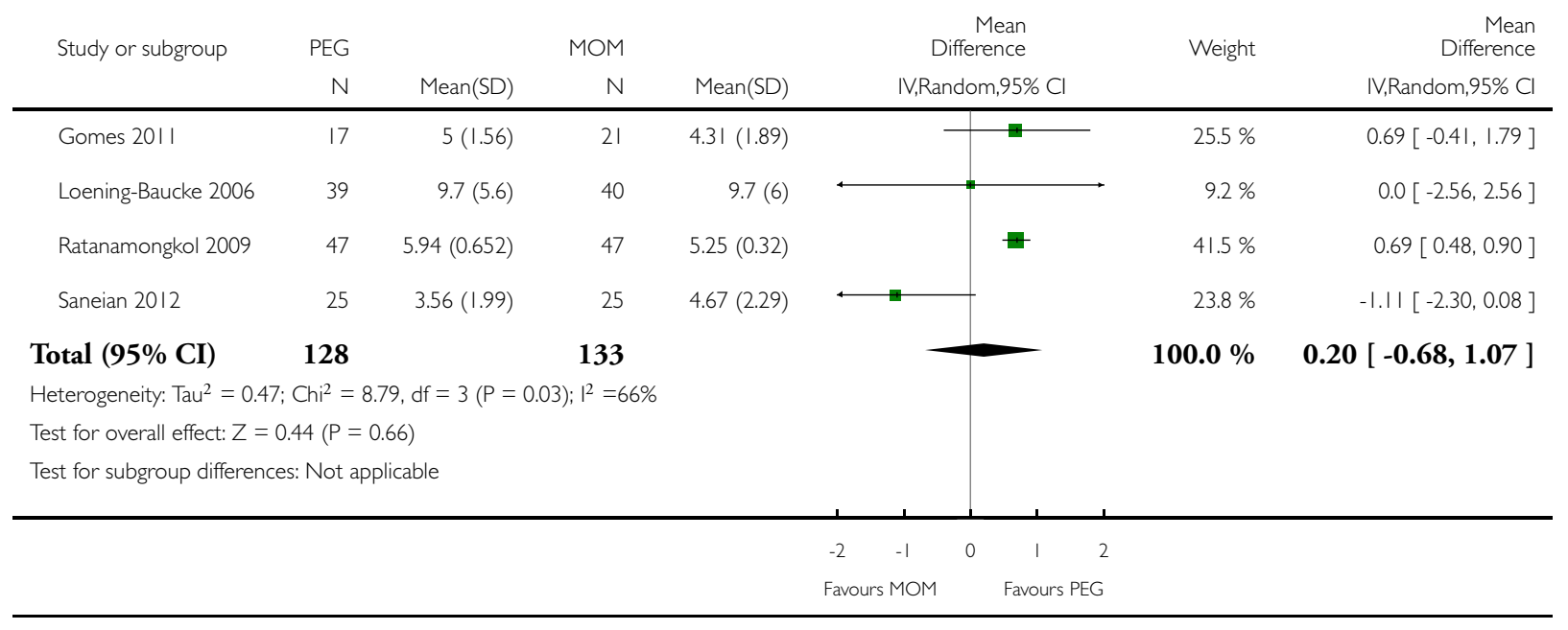

Osmotic and stimulant laxatives for the management of childhood constipation (Review)

Copyright $\odot 2016$ The Cochrane Collaboration. Published by John Wiley \& Sons, Ltd. 
Analysis 3.2. Comparison 3 PEG versus Milk of Magnesia, Outcome 2 Frequency of defecation (sensitivity analysis excluding outlier).

Review: Osmotic and stimulant laxatives for the management of childhood constipation

Comparison: 3 PEG versus Milk of Magnesia

Outcome: 2 Frequency of defecation (sensitivity analysis excluding outlier)

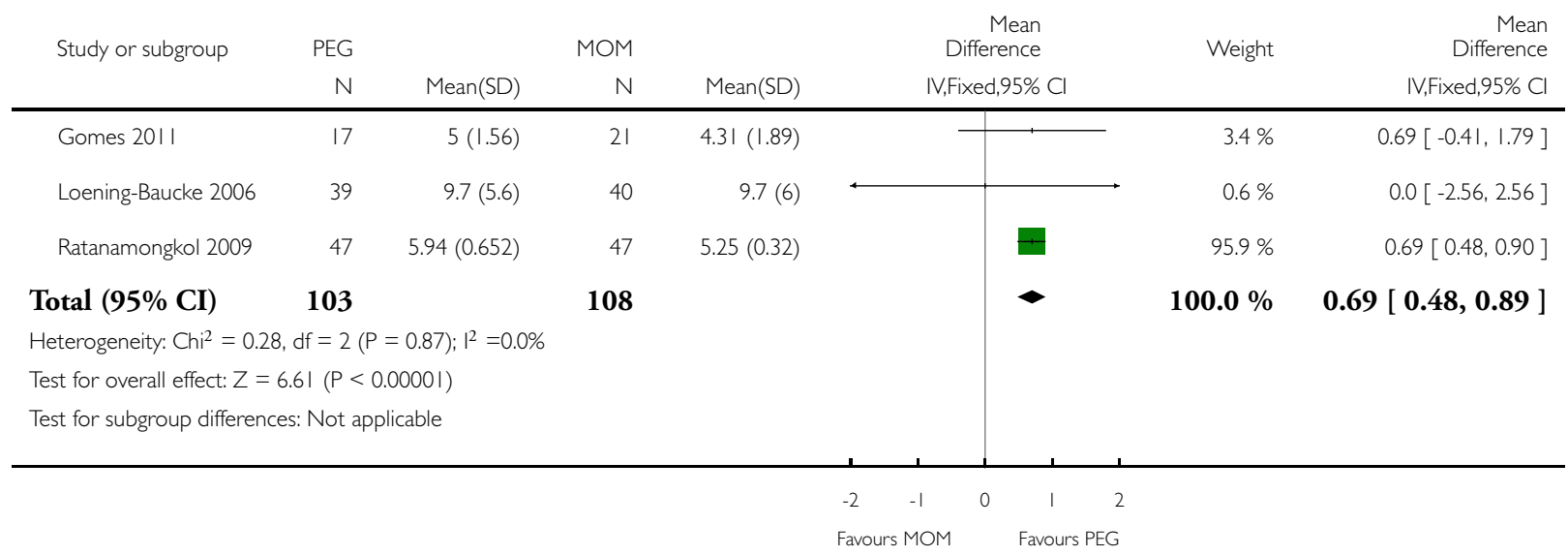




\section{Analysis 3.3. Comparison 3 PEG versus Milk of Magnesia, Outcome 3 Successful disimpaction.}

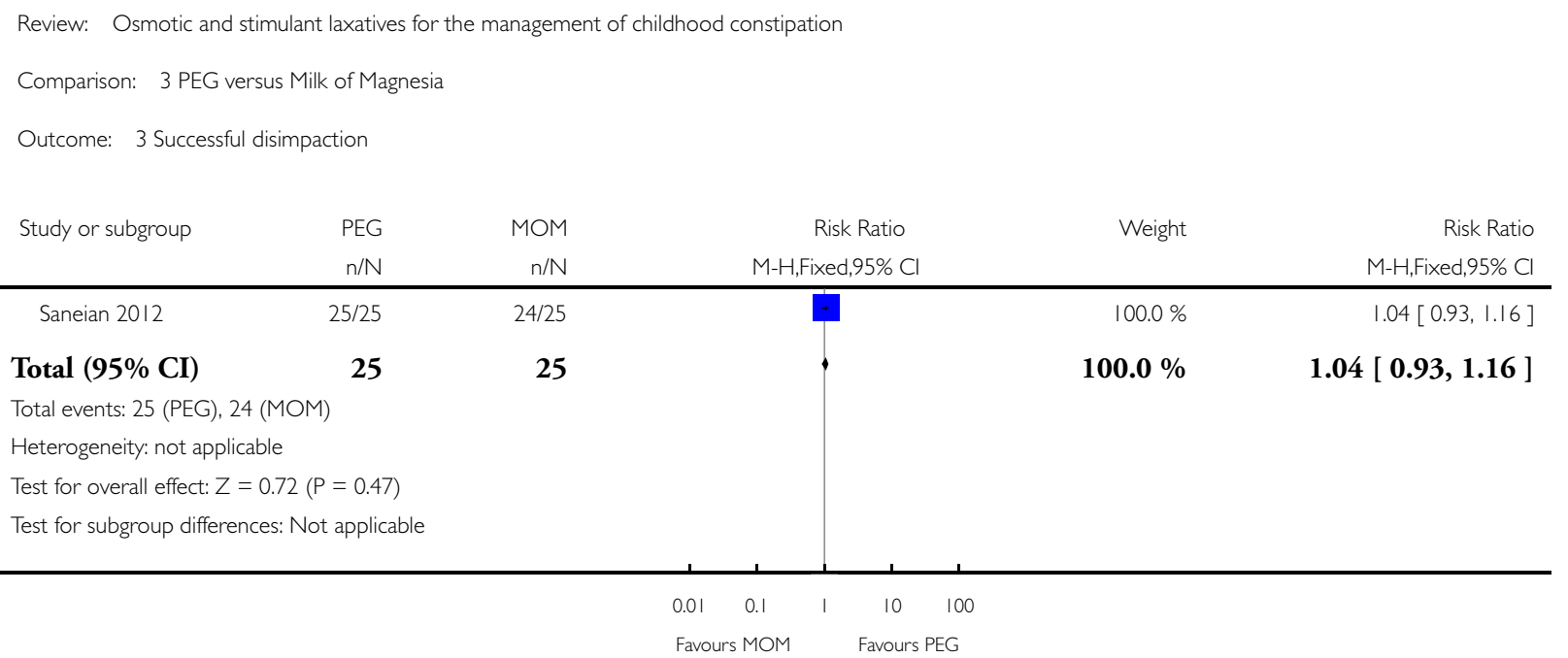

Analysis 4.I. Comparison 4 PEG versus Enema, Outcome I Frequency of defecation.

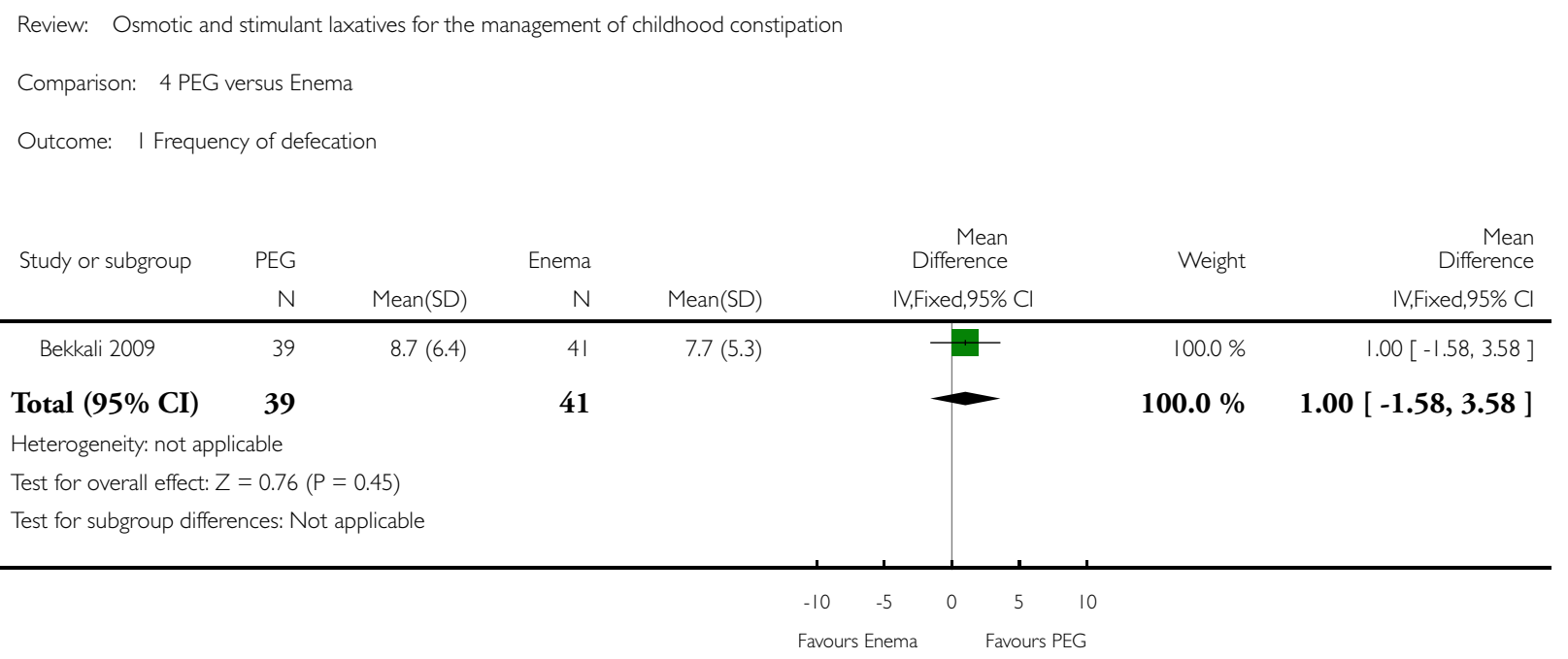




\section{Analysis 4.2. Comparison 4 PEG versus Enema, Outcome 2 Successful disimpaction.}

\begin{tabular}{|c|c|c|c|c|c|}
\hline \multicolumn{6}{|c|}{ Review: Osmotic and stimulant laxatives for the management of childhood constipation } \\
\hline \multicolumn{6}{|c|}{ Comparison: 4 PEG versus Enema } \\
\hline \multicolumn{6}{|c|}{ Outcome: 2 Successful disimpaction } \\
\hline \multirow[t]{2}{*}{ Study or subgroup } & PEG & Enema & Risk Ratio & Weight & Risk Ratio \\
\hline & $\mathrm{n} / \mathrm{N}$ & $\mathrm{n} / \mathrm{N}$ & M-H,Fixed,95\% Cl & & M-H,Fixed,95\% Cl \\
\hline Bekkali 2009 & $30 / 44$ & $37 / 46$ & 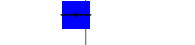 & $100.0 \%$ & $0.85[0.66,1.09]$ \\
\hline Total $(95 \% \mathrm{CI})$ & 44 & 46 & - & $100.0 \%$ & $0.85[0.66,1.09]$ \\
\hline \multicolumn{6}{|c|}{ Total events: 30 (PEG), 37 (Enema) } \\
\hline \multicolumn{6}{|c|}{ Heterogeneity: not applicable } \\
\hline \multicolumn{6}{|c|}{ Test for overall effect: $Z=1.31(P=0.19)$} \\
\hline \multicolumn{6}{|c|}{ Test for subgroup differences: Not applicable } \\
\hline
\end{tabular}

\section{Analysis 5.I. Comparison 5 PEG versus Liquid Paraffin, Outcome I Frequency of defecation.}

Review: Osmotic and stimulant laxatives for the management of childhood constipation

Comparison: 5 PEG versus Liquid Paraffin

Outcome: I Frequency of defecation

\begin{tabular}{|c|c|c|c|c|c|c|c|}
\hline \multirow[t]{2}{*}{ Study or subgroup } & \multirow{2}{*}{$\begin{array}{r}\text { PEG } \\
\text { N }\end{array}$} & \multicolumn{3}{|c|}{ Paraffin } & \multirow{2}{*}{$\begin{array}{c}\text { Mean } \\
\text { Difference } \\
\text { IV,Fixed,95\% Cl }\end{array}$} & \multirow[t]{2}{*}{ Weight } & \multirow{2}{*}{$\begin{array}{r}\text { Mean } \\
\text { Difference } \\
\text { IV,Fixed,95\% Cl }\end{array}$} \\
\hline & & Mean(SD) & N & Mean(SD) & & & \\
\hline Karami 2009 & 48 & $4.7(1.8)$ & 55 & $4.5(1.9)$ & $\because$ & $69.5 \%$ & $0.20[-0.52,0.92]$ \\
\hline Rafati 2011 & 80 & $7(3.8)$ & 78 & $6.3(3.1)$ & + & $30.5 \%$ & $0.70[-0.38,1.78]$ \\
\hline Total $(95 \% \mathrm{CI})$ & 128 & & 133 & & - & $100.0 \%$ & $0.35[-0.24,0.95]$ \\
\hline \multicolumn{8}{|c|}{ Heterogeneity: $\mathrm{Ch}^{2}=0.57, \mathrm{df}=\mathrm{I}(P=0.45) ; \mathrm{I}^{2}=0.0 \%$} \\
\hline \multicolumn{8}{|c|}{ Test for overall effect: $Z=1.16(P=0.25)$} \\
\hline \multicolumn{8}{|c|}{ Test for subgroup differences: Not applicable } \\
\hline & & & & & 0 & & \\
\hline
\end{tabular}




\section{Analysis 6.I. Comparison 6 PEG versus Flixweed, Outcome I Frequency of defecation.}

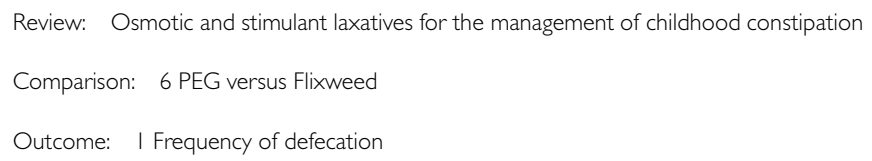

\begin{tabular}{|c|c|c|c|c|c|c|c|}
\hline \multirow[t]{2}{*}{ Study or subgroup } & \multirow{2}{*}{$\begin{array}{r}\text { PEG } \\
N\end{array}$} & \multicolumn{3}{|c|}{ Flixweed } & $\begin{array}{r}\text { Mean } \\
\text { Difference }\end{array}$ & \multirow[t]{2}{*}{ Weight } & \multirow{2}{*}{$\begin{array}{r}\text { Mean } \\
\text { Difference } \\
\text { IV,Random,95\% Cl }\end{array}$} \\
\hline & & Mean(SD) & $N$ & Mean(SD) & IV,Random,95\% Cl & & \\
\hline Nimrouzi 2015 & 53 & $5(0.75)$ & 56 & $5(1)$ & + & $100.0 \%$ & $0.0[-0.33,0.33]$ \\
\hline Total $(95 \%$ CI $)$ & 53 & & 56 & & - & $100.0 \%$ & $0.0[-0.33,0.33]$ \\
\hline \multicolumn{8}{|c|}{ Heterogeneity: not applicable } \\
\hline \multicolumn{8}{|c|}{ Test for overall effect: $Z=0.0(P=1.0)$} \\
\hline \multicolumn{8}{|c|}{ Test for subgroup differences: Not applicable } \\
\hline & & & & & -1 & & \\
\hline
\end{tabular}

\section{Analysis 6.2. Comparison 6 PEG versus Flixweed, Outcome 2 Need for additional therapies.}

Review: Osmotic and stimulant laxatives for the management of childhood constipation

Comparison: 6 PEG versus Flixweed

Outcome: 2 Need for additional therapies

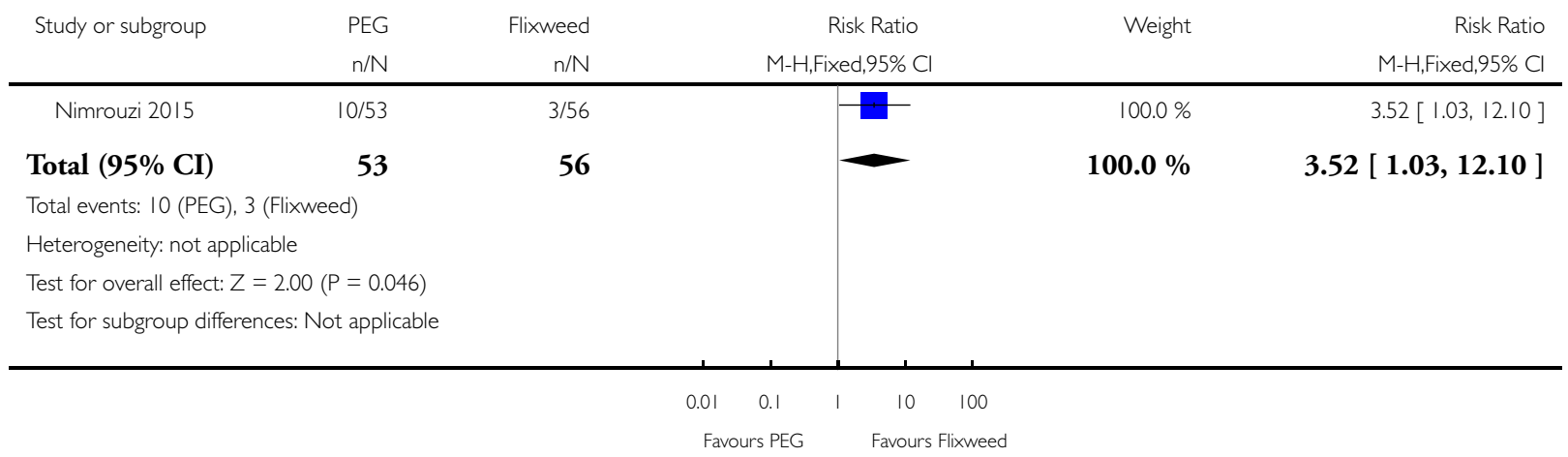




\section{Analysis 7.I. Comparison 7 PEG versus Dietary fibre mix, Outcome I Frequency of defecation.}

Review: Osmotic and stimulant laxatives for the management of childhood constipation

Comparison: 7 PEG versus Dietary fibre mix

Outcome: I Frequency of defecation

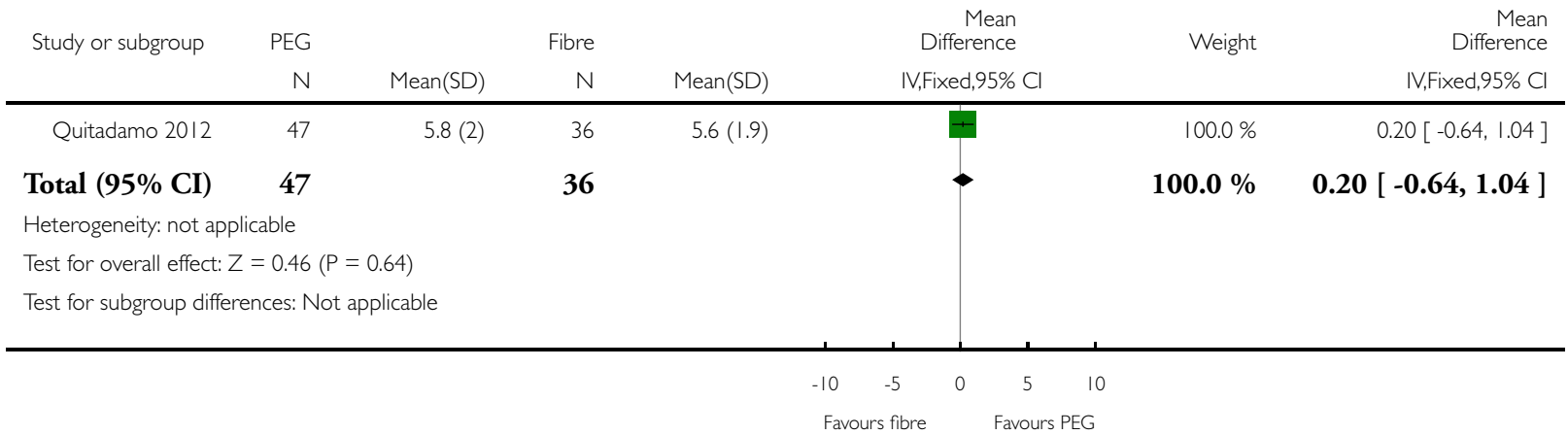

Analysis 7.2. Comparison 7 PEG versus Dietary fibre mix, Outcome 2 Need for additional therapy.

Review: Osmotic and stimulant laxatives for the management of childhood constipation

Comparison: 7 PEG versus Dietary fibre mix

Outcome: 2 Need for additional therapy

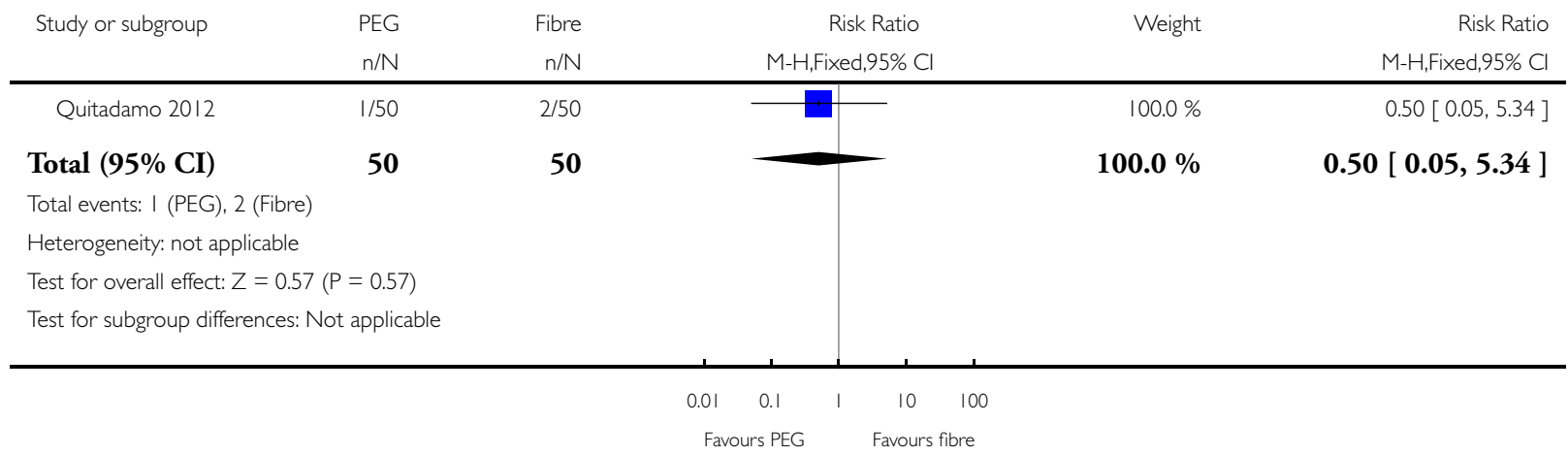


Analysis 7.3. Comparison 7 PEG versus Dietary fibre mix, Outcome 3 Frequency of faecal incontinence.

Review: Osmotic and stimulant laxatives for the management of childhood constipation

Comparison: 7 PEG versus Dietary fibre mix

Outcome: 3 Frequency of faecal incontinence

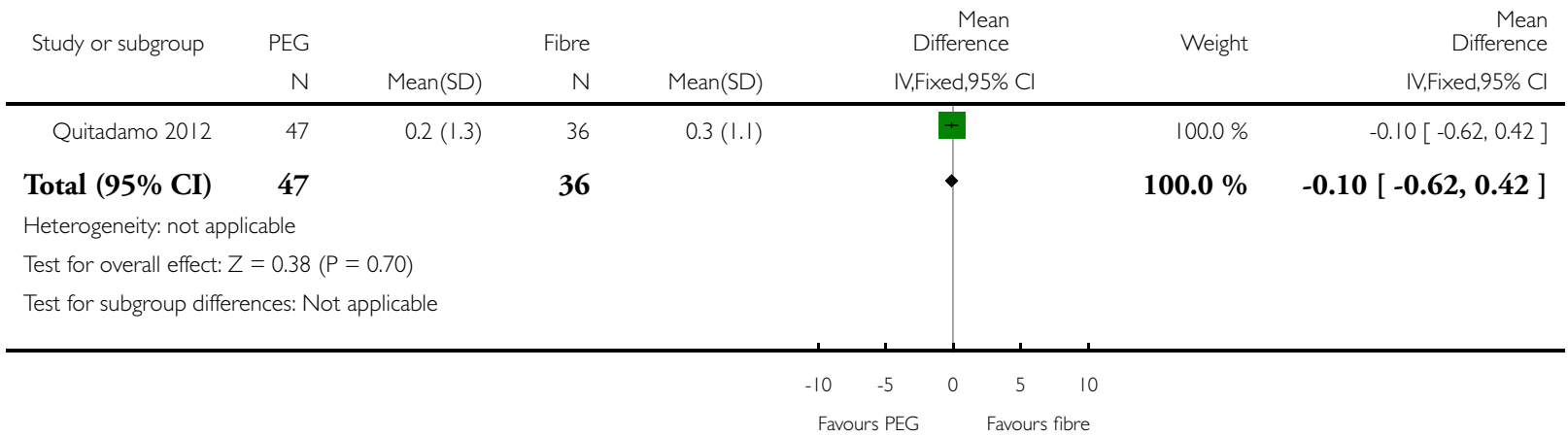

\section{Analysis 8.I. Comparison 8 High dose PEG versus low dose PEG, Outcome I Frequency of defecation.}

Review: Osmotic and stimulant laxatives for the management of childhood constipation

Comparison: 8 High dose PEG versus low dose PEG

Outcome: | Frequency of defecation

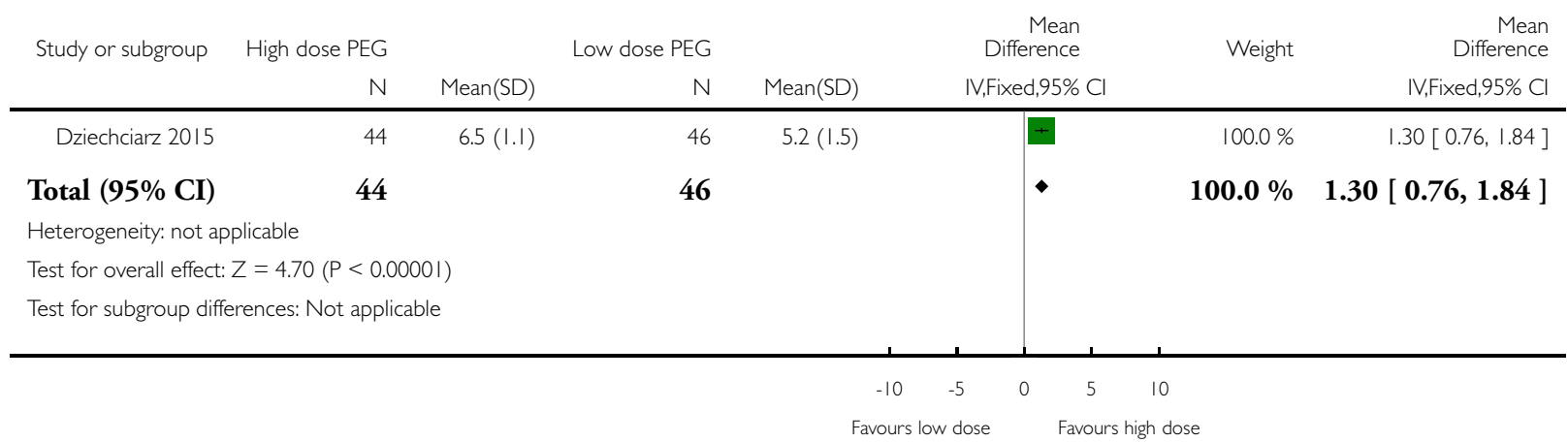




\section{Analysis 8.2. Comparison 8 High dose PEG versus low dose PEG, Outcome 2 Need for additional therapy.}

\begin{tabular}{|c|c|c|c|c|c|}
\hline \multicolumn{6}{|c|}{ Review: Osmotic and stimulant laxatives for the management of childhood constipation } \\
\hline \multicolumn{6}{|c|}{ Comparison: 8 High dose PEG versus low dose PEG } \\
\hline \multicolumn{6}{|c|}{ Outcome: 2 Need for additional therapy } \\
\hline \multirow[t]{2}{*}{ Study or subgroup } & High dose PEG & Low dose PEG & Risk Ratio & Weight & Risk Ratio \\
\hline & $\mathrm{n} / \mathrm{N}$ & $\mathrm{n} / \mathrm{N}$ & M-H,Fixed,95\% Cl & & M-H,Fixed,95\% Cl \\
\hline Dziechciarz 2015 & $8 / 44$ & $17 / 46$ & + & $100.0 \%$ & $0.49[0.24,1.02]$ \\
\hline Total $(95 \%$ CI $)$ & 44 & 46 & $\longrightarrow$ & $100.0 \%$ & $0.49[0.24,1.02]$ \\
\hline \multicolumn{6}{|c|}{ Total events: 8 (High dose PEG), 17 (Low dose PEG) } \\
\hline \multicolumn{6}{|c|}{ Heterogeneity: not applicable } \\
\hline \multicolumn{6}{|c|}{ Test for overall effect: $Z=1.90(P=0.057)$} \\
\hline \multicolumn{6}{|c|}{ Test for subgroup differences: Not applicable } \\
\hline
\end{tabular}

\section{Analysis 8.3. Comparison 8 High dose PEG versus low dose PEG, Outcome 3 Faecal incontinence.}

Review: Osmotic and stimulant laxatives for the management of childhood constipation

Comparison: 8 High dose PEG versus low dose PEG

Outcome: 3 Faecal incontinence

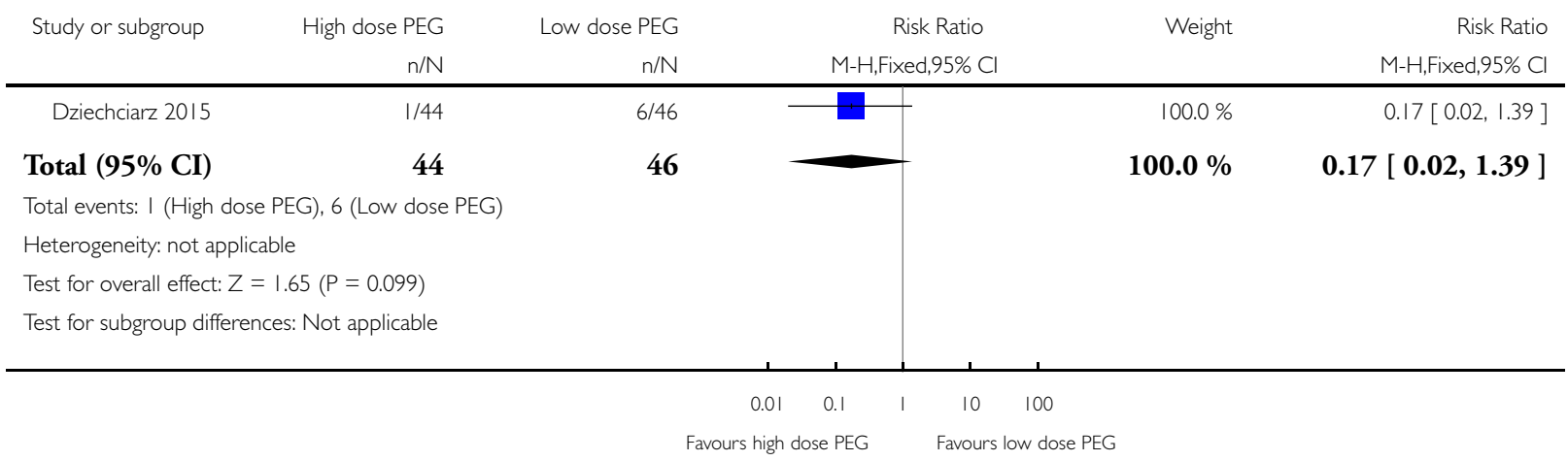




\section{Analysis 8.4. Comparison 8 High dose PEG versus low dose PEG, Outcome 4 Adverse events.}

Review: Osmotic and stimulant laxatives for the management of childhood constipation

Comparison: 8 High dose PEG versus low dose PEG

Outcome: 4 Adverse events

\begin{tabular}{|c|c|c|c|c|c|}
\hline \multirow[t]{2}{*}{ Study or subgroup } & High dose PEG & Low dose PEG & Risk Ratio & Weight & Risk Ratio \\
\hline & $\mathrm{n} / \mathrm{N}$ & $\mathrm{n} / \mathrm{N}$ & M-H,Fixed,95\% Cl & & M-H,Fixed,95\% Cl \\
\hline Dziechciarz 2015 & $4 / 44$ & $3 / 46$ & . & $100.0 \%$ & $1.39[0.33,5.88]$ \\
\hline Total (95\% CI) & 44 & 46 & & $100.0 \%$ & $1.39[0.33,5.88]$ \\
\hline
\end{tabular}

Total events: 4 (High dose PEG), 3 (Low dose PEG)

Heterogeneity: not applicable

Test for overall effect: $Z=0.45(P=0.65)$

Test for subgroup differences: Not applicable

$\begin{array}{ccccc}0.01 & 0.1 & 1 & 10 & 100 \\ \text { Favours high dose } & \text { PEG } & \text { Favours low dose PEG }\end{array}$

\section{Analysis 9.I. Comparison 9 Liquid Paraffin versus Lactulose, Outcome I Frequency of defecation.}

Review: Osmotic and stimulant laxatives for the management of childhood constipation

Comparison: 9 Liquid Paraffin versus Lactulose

Outcome: I Frequency of defecation

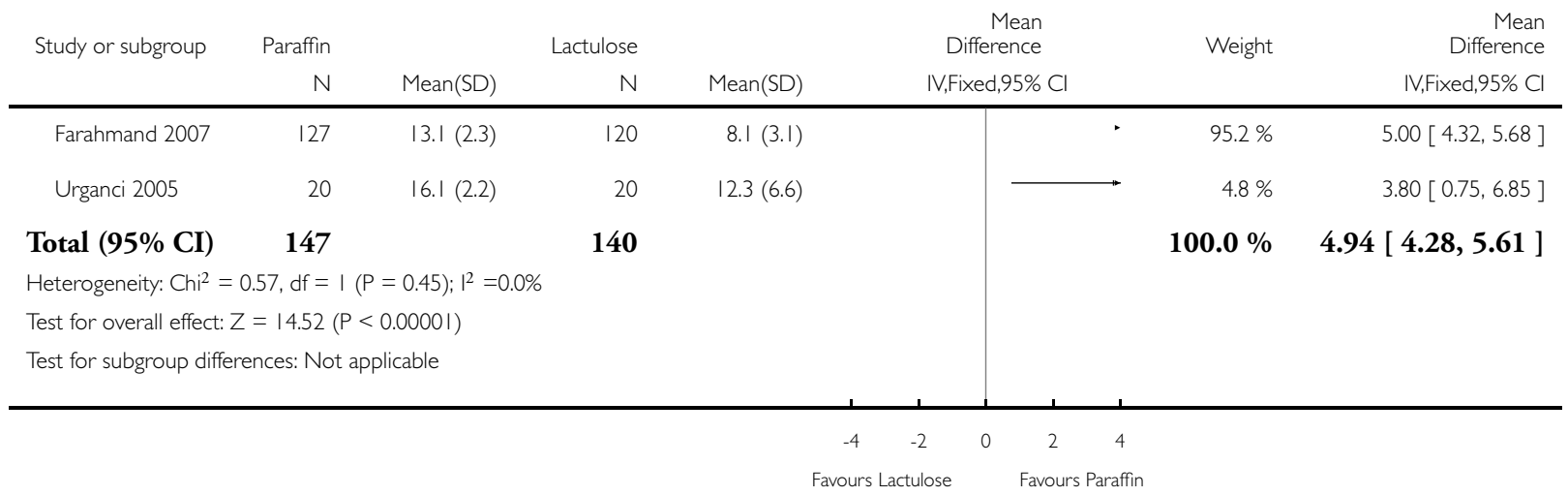




\section{Analysis 10.I. Comparison I0 Lactulose versus Lactitol, Outcome I Frequency of defecation.}

Review: Osmotic and stimulant laxatives for the management of childhood constipation

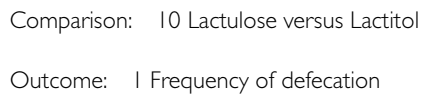

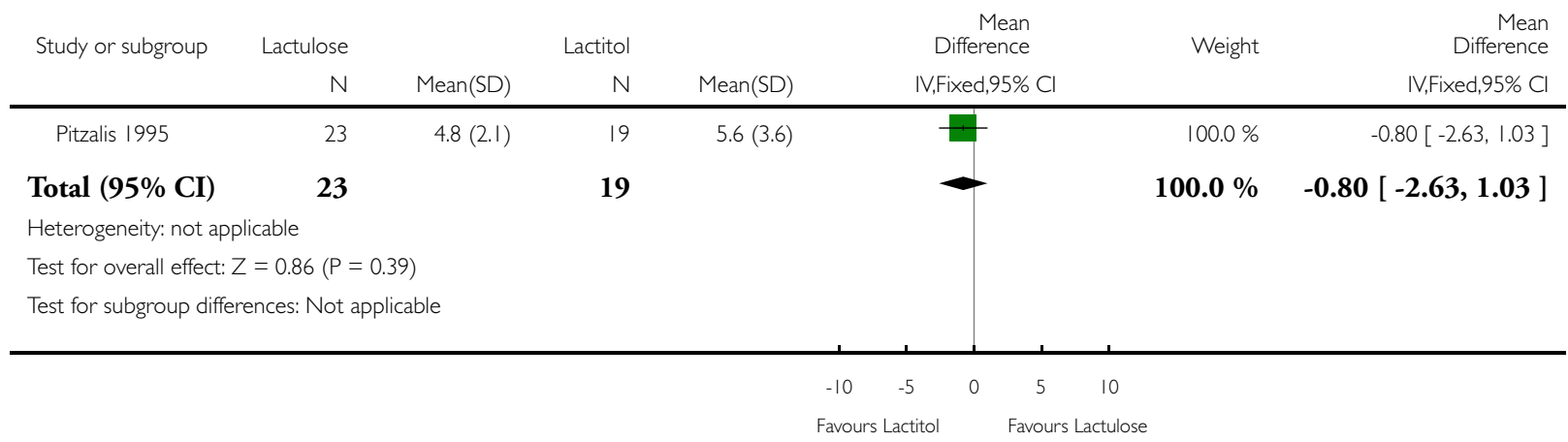

\section{Analysis I I.I. Comparison I I Lactulose versus Milk of Magnesia, Outcome I Frequency of defecation.}

Review: Osmotic and stimulant laxatives for the management of childhood constipation

Comparison: I Lactulose versus Milk of Magnesia

Outcome: | Frequency of defecation

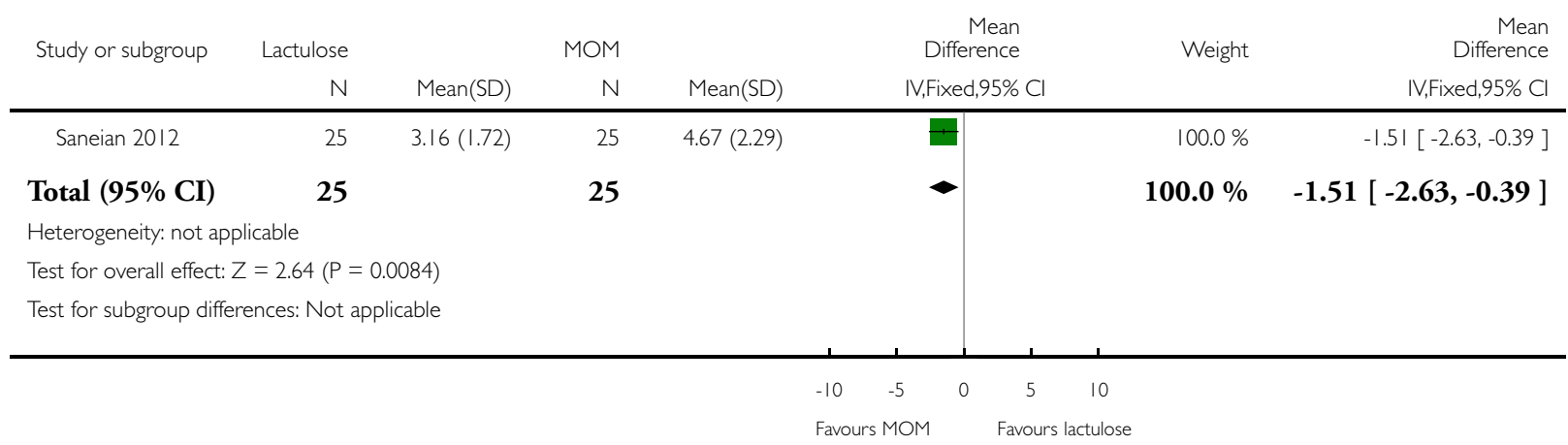


Analysis I I.2. Comparison I I Lactulose versus Milk of Magnesia, Outcome 2 Need for additional therapy.

Review: Osmotic and stimulant laxatives for the management of childhood constipation

Comparison: II Lactulose versus Milk of Magnesia

Outcome: 2 Need for additional therapy

\begin{tabular}{|c|c|c|c|c|c|}
\hline \multirow[t]{2}{*}{ Study or subgroup } & Lactulose & MOM & Risk Ratio & Weight & Risk Ratio \\
\hline & $\mathrm{n} / \mathrm{N}$ & $\mathrm{n} / \mathrm{N}$ & M-H,Fixed,95\% Cl & & M-H,Fixed,95\% Cl \\
\hline Saneian 2012 & $10 / 25$ & $5 / 25$ & & $100.0 \%$ & $2.00[0.80,5.02]$ \\
\hline Total (95\% CI) & 25 & 25 & & $100.0 \%$ & $2.00[0.80,5.02]$ \\
\hline
\end{tabular}

Total events: 10 (Lactulose), 5 (MOM)

Heterogeneity: not applicable

Test for overall effect: $Z=1.48(P=0.14)$

Test for subgroup differences: Not applicable

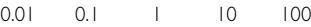

Favours lactulose Favours MOM

Analysis I I.3. Comparison I I Lactulose versus Milk of Magnesia, Outcome 3 Successful disimpaction.

Review: Osmotic and stimulant laxatives for the management of childhood constipation

Comparison: I I Lactulose versus Milk of Magnesia

Outcome: 3 Successful disimpaction

\begin{tabular}{|c|c|c|c|c|c|}
\hline \multirow[t]{2}{*}{ Study or subgroup } & Lactulose & MOM & Risk Ratio & \multirow[t]{2}{*}{ Weight } & Risk Ratio \\
\hline & $\mathrm{n} / \mathrm{N}$ & $\mathrm{n} / \mathrm{N}$ & M-H,Fixed,95\% Cl & & M-H,Fixed,95\% Cl \\
\hline Saneian 2012 & $20 / 25$ & $24 / 25$ & & $100.0 \%$ & $0.83[0.67,1.03]$ \\
\hline Total (95\% CI) & 25 & 25 & $\bullet$ & $100.0 \%$ & $0.83[0.67,1.03]$ \\
\hline \multicolumn{6}{|c|}{ Total events: 20 (Lactulose), 24 (MOM) } \\
\hline \multicolumn{6}{|c|}{ Heterogeneity: not applicable } \\
\hline \multicolumn{6}{|c|}{ Test for overall effect: $Z=1.69(P=0.091)$} \\
\hline Test for subgroup diff & ot applicable & & & & \\
\hline
\end{tabular}

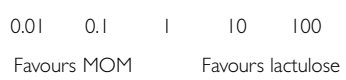

Osmotic and stimulant laxatives for the management of childhood constipation (Review) 


\section{Analysis I2.I. Comparison I2 Lactulose versus Partially Hydrolyzed Guar Gum, Outcome I Frequency of defecation.}

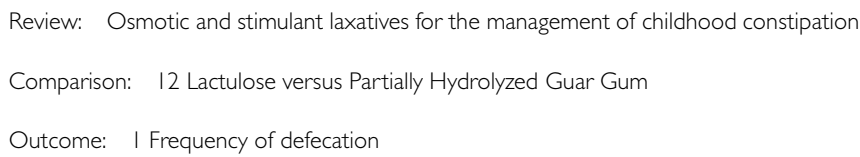

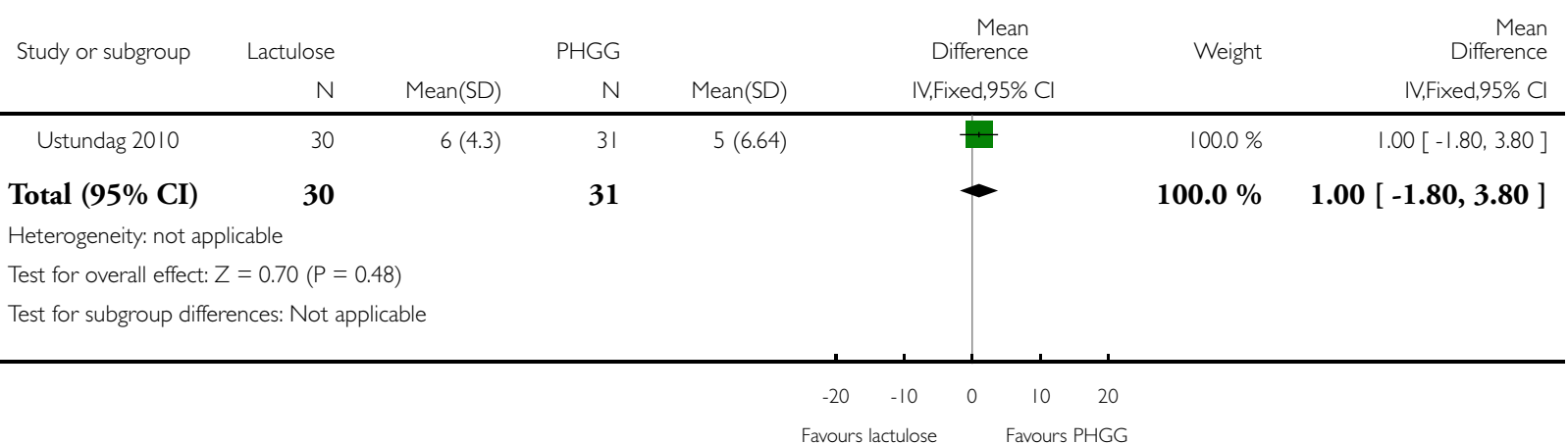

\section{A P P E N D I C ES}

\section{Appendix I. Search Strategy}

\section{Electronic searches}

1. MEDLINE (1966 to March 11, 2016; National Library of Medicine, Bethesda, USA)

1. randomized controlled trial.pt.

2. controlled clinical trial.pt.

3. randomized.ab.

4. placebo.ab.

5. clinical trials as topic.sh.

6. randomly.ab.

7. trial.ti.

8. or/1-7

9. exp animals/ not humans.sh.

10. 8 not 9

11. exp constipation/

12. impaction.mp.

13. delayed bowel movement.mp.

14. obstipation.mp.

15. costiveness.mp.

16. defecation.mp.

17. bowel function*.mp.

18. bowel habit*.mp.

19. bowel movement*.mp.

Osmotic and stimulant laxatives for the management of childhood constipation (Review)

Copyright $\Subset 2016$ The Cochrane Collaboration. Published by John Wiley \& Sons, Ltd. 
20. bowel symptom*.mp.

21. bowel motility.mp.

22. colon transit.mp.

23. evacuation.mp.

24. intestinal motility.mp.

25. stool*.mp.

26. or/11-25

27. laxative.mp.

28. (polyethylene glycol* OR macrogol* OR PEG OR Miralax OR Transipeg OR Movicol OR Forlax OR Idrolax OR GoLytely OR PMF-100 OR Golitely OR Nulitely OR Fortans OR TriLyte OR Colyte OR lactulose OR disaccharide OR Apo-Lactulose OR Chronulac OR lactitol OR sorbitol OR Generlac OR Cephulac OR Cholac OR Constilac OR Enulose OR cilac OR Heptalac OR Actilax OR Duphalac OR Kristalose OR milk of magnesia OR magnesium hydroxide OR Magnesium citrate OR citroma OR Osmoprep OR Visicol OR senna OR docusate sodium OR Sodium picosulphate OR Bisacodyl OR Cascara OR casanthranol OR Buckthorn OR senokot OR Aloe Vera OR aloin Phenolphthalein OR Dulcolax OR osmotic).mp.

29. 27 OR 28

30. exp child/

31. exp infant/

32. exp adolescent/

33. (child* OR paediat* OR pediat* OR neonat* OR toddler OR young).mp.

34. OR/31-34

35. 10 AND 26 AND 29 AND 34

2. EMBASE (1984 to March 11, 2016; Elsevier Science, New York, USA)

1. random $\$$.tw.

2. factorial\$.tw.

3. (crossover\$ or cross over $\$$ or cross-over $\$$ ).tw.

4. placebo $\$ . t w$.

5. single blind.mp.

6. double blind.mp.

7. triple blind.mp.

8. (singl\$ adj blind\$).tw.

9. (double $\$$ adj blind $\$$ ).tw.

10. (tripl\$ adj blind\$).tw.

11. assign $\$$.tw.

12. allocat\$.tw.

13. crossover procedure/

14. double blind procedure/

15. single blind procedure/

16. triple blind procedure/

17. randomized controlled trial/

18. or/1-17

19. (exp animal/ or animal.hw. or nonhuman/) not (exp human/ or human cell/ or (human or humans).ti.)

20. 18 not 19

21. exp constipation/

22. impaction.mp.

23. delayed bowel movement.mp.

24. obstipation.mp.

25. costiveness.mp.

26. defecation.mp.

27. bowel function*.mp.

28. bowel habit*.mp.

29. bowel movement*.mp.

30. bowel symptom*.mp.

31. bowel motility.mp.

Osmotic and stimulant laxatives for the management of childhood constipation (Review)

Copyright $\odot 2016$ The Cochrane Collaboration. Published by John Wiley \& Sons, Ltd. 
32. colon transit.mp.

33. evacuation.mp.

34. intestinal motility.mp.

35. stool* $^{*}$.mp.

36. or/21-35

37. laxative.mp.

38. (polyethylene glycol* OR macrogol* OR PEG OR Miralax OR Transipeg OR Movicol OR Forlax OR Idrolax OR GoLytely OR PMF-100 OR Golitely OR Nulitely OR Fortans OR TriLyte OR Colyte OR lactulose OR disaccharide OR Apo-Lactulose OR Chronulac OR lactitol OR sorbitol OR Generlac OR Cephulac OR Cholac OR Constilac OR Enulose OR cilac OR Heptalac OR Actilax OR Duphalac OR Kristalose OR milk of magnesia OR magnesium hydroxide OR Magnesium citrate OR citroma OR Osmoprep OR Visicol OR senna OR docusate sodium OR Sodium picosulphate OR Bisacodyl OR Cascara OR casanthranol OR Buckthorn OR senokot OR Aloe Vera OR aloin Phenolphthalein OR Dulcolax OR osmotic).mp.

39. 37 OR 38

40. exp child/

41. exp infant/

42. exp adolescent/

43. (child* OR paediat* OR pediat* OR neonat* OR toddler OR young).mp.

44. OR/40-43

45. 20 AND 36 AND 39 AND 44

3. Cochrane Central Register of Controlled Trials

\#1 MeSH descriptor: [Constipation] explode all trees

\#2 (impaction OR "delayed bowel movement" or obstipation or costiveness or defecation or "bowel function" or "bowel habit" or "bowel movement" or "bowel symptom" or "bowel motility" or "colon transit" or "evacuation" or "intestinal motility" or "stool”)

\#3 MeSH descriptor: [Child] explode all trees

\#4 MeSH descriptor: [Adolescent] explode all trees

\#5 MeSH descriptor: [Infant] explode all trees

\#6 child* or paediat* or pediat* or neonat* ${ }^{*}$ or toddler or young

$\# 7$ \#3 or \#4 or \#5 or \#6

$\# 8 \# 1$ or \#3

$\# 9$ \#7 and \#8

\section{Cochrane IBD Group Specialized Trials Register}

1. Title/abstract: impaction OR "delayed bowel movement" or obstipation or costiveness or defecation or "bowel function" or "bowel habit" or "bowel movement" or "bowel symptom" or "bowel motility" or "colon transit" or "evacuation" or "intestinal motility" or "stool"

2. Title/abstract: child* or paediat* or pediat* or neonat* or toddler or young

3. 1 AND 2

\section{WHAT'S NEW}

Last assessed as up-to-date: 10 March 2016.

\begin{tabular}{lll}
\hline Date & Event & Description \\
\hline 10 March 2016 & New search has been performed & $\begin{array}{l}\text { A new literature was conducted on 10 March 2016. New } \\
\text { studies added }\end{array}$ \\
\hline 10 March 2016 & New citation required and conclusions have changed & $\begin{array}{l}\text { Updated review with some new conclusions and new au- } \\
\text { thors }\end{array}$ \\
\hline
\end{tabular}

Osmotic and stimulant laxatives for the management of childhood constipation (Review) 


\section{DECLARATIONSOF INTEREST}

Morris Gordon has received travel expenses from Tillotts, Ferring, Clinova, and Danone to attend scientific meetings and present results or chair sessions. All of these financial activities are outside the scope of the present review.

John K MacDonald: None known.

Claire E Parker: None known.

Anthony K Akobeng: None known.

Adrian G Thomas: None known.

\section{N D EX TERMS}

Medical Subject Headings (MeSH)

Constipation [*drug therapy]; Defecation [drug effects; physiology]; Dietary Fiber [adverse effects; therapeutic use]; Lactulose [adverse effects; therapeutic use]; Laxatives [adverse effects; * therapeutic use]; Magnesium Hydroxide [adverse effects; therapeutic use]; Mineral Oil [adverse effects; therapeutic use]; Osmosis; Polyethylene Glycols [adverse effects; therapeutic use]; Randomized Controlled Trials as Topic; Sugar Alcohols [adverse effects; therapeutic use]

\section{MeSH check words}

Adolescent; Child; Child, Preschool; Humans; Infant 